\title{
El firmamento en un cuenco de cerámica. Viaje a las ideas calcolíticas sobre la bóveda celeste.
}

José Luis ESCACENA CARRASCO 1

Dijo Dios: «Haya un firmamento por en medio de las aguas, que las aparte unas de otras.»

Génesis $1,6^{2}$

\section{Resumen}

Las concepciones del cosmos fueron comunes a muchos ámbitos antiguos del Mediterráneo. Por ello, la información gráfica y textual procedente de civilizaciones orientales con escritura permite explicar imágenes halladas en regiones europeas occidentales con culturas prehistóricas ágrafas, donde los testimonios son más simples y esquemáticos. Se analizan aquí algunos documentos hispanos que pueden ser interpretados como representaciones del cielo.

Palabras clave: Disco de Nebra, arte esquemático, barca sagrada, Neolítico, Calcolítico, Edad del Bronce, imágenes astrales, cielo.

\section{Summary}

The conceptions of the cosmos were common to many ancient Mediterranean areas. Therefore, the graphical and textual information from Eastern civilizations with writing systems allow to explain images found on Western European regions with preliterate prehistoric cultures, in which the evidence is more simple and schematic. We analyze here some Hispanics documents which can be interpreted as representations of the sky.

Keywords: Nebra disc, schematic art, sacred ship, Neolithic, Chalcolithic, Bronze Age, astral images, sky.

\section{Dedicatoria y Agradecimientos}

De pequeño, un servidor quería ser astrónomo; pero más tarde me vino una vocación más fuerte por la historia humana, sobre todo por la más antigua. Como tantas otras veces les ocurre a los jóvenes, algunos de mis profesores de bachillerato fueron parcialmente responsables de mis cambios, tanto para bien como para mal. Así que dejé de mirar a las estrellas para dirigir mis ojos a la tierra, donde quedaban las huellas de ese pasado remoto. Con el tiempo he logrado levantar de

1 Departamento de Prehistoria y Arqueología. Universidad de Sevilla. nuevo la vista para unir ambos intereses. Este largo artículo es fruto de esa doble entrega. Lo dedico al profesor Bendala en recuerdo de una confluencia de disciplinas -la arqueología y la astronomía- que él también supo ver cuando estudió la Tumba del Elefante, en la necrópolis romana de Carmona (Bendala 1976: 60-61). Espero que lo propuesto en él sea de su agrado e interés; y sospecho además que, por su vasto conocimiento del Mediterráneo antiguo, será una de las personas que más provecho saque de su lectura si el trabajo lo tuviera.

2 Los textos bíblicos citados en el presente artículo pertenecen a la traducción de la Biblia de Jerusalén. 
Para este estudio, elaborado en el marco del Proyecto HAR2008-01119 y del Grupo HUM402 del III Plan Andaluz de Investigación, he recibido la valiosa ayuda de diversos colegas y amigos. No puedo olvidar, entre ellos, a César Esteban López (Instituto Astrofísico de Canarias), a María Belén Deamos, Pilar León-Castro Alonso, María Luisa de la Bandera Romero, Daniel García Rivero, José Miguel Serrano Delgado, Oliva Rodríguez Gutiérrez y Miguel Cortés Sánchez (Universidad de Sevilla), a Beatriz Gavilán Ceballos (Universidad de Huelva), a Juan Antonio Cámara Serrano (Universidad de Granada), a José Ángel Zamora López (Centro de Ciencias Humanas y Sociales del CSIC), a Antonio J. Morales Rendón (University of Pennsylvania), a Hipólito Collado Giraldo (Consejería de Cultura de la Junta de Extremadura), y a Antonio Conejo Rivas, presidente de la asociación Amigos del Patrimonio de Zalamea la Real (Huelva). Finalmente, estoy en deuda también, por el permiso para reproducir algunas fotografías de arte rupestre, con Javier Pérez González y Rafael Maura Mijares (Conjunto Arqueológico Dólmenes de Antequera). Mi agradecimiento a todos.

\section{Periplo Mediterráneo}

Desde los años setenta del siglo pasado, la investigación de la Prehistoria Reciente europea dejó de mirar a Oriente como foco dispersor de innovaciones culturales. El abuso de la difusión como explicación casi única de las transformaciones económicas, sociales y tecnológicas, especialmente de estas últimas, produjo un movimiento historiográfico pendular que acabó colocando a la mayor parte de los estudiosos en el polo opuesto. De esta forma, los procesos locales autóctonos y autónomos de cada región se convirtieron desde entonces, y durante bastantes años, casi en la única meta de investigación; eso sí, como una estrategia compartida por posiciones teóricas en principio distintas y excluyentes. Este vuelco dispuso de algunos protagonistas españoles que rechazaron el orientalismo como principio explicador de todo, o que reivindicaron incluso influencias culturales contrarias, en dirección oeste-este (p.e. Bosch 1966); pero en el ámbito europeo tuvo sin duda a C. Renfrew como uno de sus valedores principales. Por lo que se refiere a la Península Ibérica, su artículo de 1967 titulado "Colonialism and megalithismus" puede conside- rarse un punto de inflexión en el estudio de la Edad del Cobre, aunque no con efectos inmediatos desde luego. Un ejemplo concreto de este giro lo constituye, entre otras obras, la tesis doctoral de A. Hernando, donde la autora recoge explícitamente la negativa a que el difusionismo metodológico sirva para dar cuenta de "la aparición de rasgos culturales complejos" como el uso del metal, el colectivismo funerario o los procesos de fortificación de los asentamientos (Hernando 1988: 9). Hasta hace poco, los enrocamientos en el antidifusionismo han desembocado en la negación incomprensible de la propagación de rasgos, elementos y conductas como otra variable más a tener en cuenta para la explicación del cambio cultural; y ello a pesar de que el propio Renfrew (1988) cambió de estrategia al abordar el análisis de la diáspora neolítica y de la paralela expansión de las lenguas indoeuropeas. En esta cuestión metodológica, parece como si sus seguidores hubiesen permanecido anclados en el Renfrew de los años sesenta.

Hoy las posiciones teóricas comienzan a tomar otros derroteros menos extremos, reflejo de lo cual puede ser el tema central elegido para el II Congreso de Prehistoria de Andalucía, celebrado en Antequera en febrero de 2012 con el título de Movilidad, Contacto y Cambio. De todas formas, el enfoque del presente artículo quiere huir también de otra posible mudanza a un neodifusionismo que, a modo de metamorfosis paulina, venga ahora a decir "digo" donde antes dijo "Diego", como si se tratara de un repentino, converso y cegador -nunca mejor dicho- descubrimiento del Mediterráneo. Tampoco es una reivindicación del Levante al modo como lo hizo la máxima historiográfica ex oriente lux, una estrategia que presidió estudios pioneros sobre el Calcolítico del mediodía ibérico estrechamente relacionados con el tema del presente trabajo (Siret 1907; 1908).

Los partidarios del autoctonismo a ultranza y quienes, desde la acera contraria, sólo barajaron el método difusionista, cayeron de forma reincidente en polémicas tan enconadas como estériles. En ese contexto dialéctico, incluso llegó alguna vez a emplearse el término "difusionista" como descalificación del contrario. Por ello, sería deseable no caer ahora, al cabo del tiempo, en la versión opuesta. En cualquier caso, quienes en los últimos cincuenta años han rechazado la difusión como explicación del cambio cultural, muchas veces 
más desde la obcecación fácil que desde el sentido común, no han comprendido que las transformaciones provocadas por influencias externas no niegan la evolución de las estructuras sociales y económicas, ni la de los elementos tecnológicos, mediante la propia dinámica interna de los grupos humanos. Pero los difusionistas tampoco han solido argumentar satisfactoriamente por qué la llegada de cosas, ideas y comportamientos foráneos debería hacer cambiar necesariamente aquello que encontraba en cada sitio. Generalmente, ninguna de las dos posiciones ha logrado entender que ambos fenómenos, las mutaciones propias y los préstamos ajenos, sólo originan incremento de la diversidad en las conductas y en los tecnocomplejos; y que únicamente las presiones selectivas, posteriores siempre a tal aumento de la variación, garantizan si la novedad logrará o no generalizarse. Véase aquí un análisis claramente darwinista de esta problemática.

Por tales razones, recurrir en el presente trabajo a fuentes de información orientales, usadas en concreto para explicar determinadas cuestiones de la Prehistoria reciente occidental, no tiene nada de difusionismo; ni siquiera contiene trazas de neodifusionismo invertido posmoderno. El enfoque aquí empleado pretende tomar al Mediterráneo como el nicho ecológico de ideas comunes, que eran compartidas por las culturas que se desenvolvieron en su cuenca al menos entre los milenios VI y I a.C., como de hecho se ha propuesto para comprender las semejanzas entre los idolillos orientales y los occidentales (Hurtado y Perdigones 1983: 58). Al estudiar la cerámica decorada con elementos simbólicos, documentación medular en el presente artículo, otros autores han señalado cómo este enfoque no tiene nada de novedoso (Martín y Cámalich 1982: 273), sobre todo si no se emplea como reconocimiento simplista de una deuda de todo lo occidental hacia lo oriental. En ese amplio marco geográfico habitado por grupos humanos con ideologías relativamente permeables, tal comunidad de pensamiento habría producido cosas parecidas en ámbitos relativamente distantes entre sí, que se actualizaban y evolucionaban, en parte al unísono, cuando los contactos intergrupales se acentuaban, fuesen éstos en cualquiera de las direcciones posibles. Se trata en definitiva más que nada de un problema de enfoque, de mirar lo estudiado desde la cercanía del terruño o desde la perspectiva que suministran las fotos de satélite y las navegaciones circunmediterráneas. Parecidas cuestiones ha suscitado de hecho, aunque a una escala inferior, el estudio de algunas sociedades del Calcolítico y de la Edad del Bronce del Sureste ibérico (cf. Chapman 1991: 210-222). Porque la proporción cartográfica con que abordar el fenómeno puede obstaculizar su comprensión o, por el contrario, facilitarla. El empleo exclusivo del zum ha conseguido hasta ahora algunos avances en el conocimiento emic de muchas representaciones rupestres y de la denominada "cerámica simbólica". Pero usar el gran angular puede abastecernos de hipótesis fecundas con las que trabajar y que suministren un análisis más detallado y profundo de esa misma documentación. De todas formas, si contar con evidencias y testimonios procedentes de civilizaciones con escritura, a veces coetáneas del Calcolítico occidental, en absoluto supone aceptar que este último fue deudor necesario de aquéllas, tampoco impide aceptar dicha dependencia si hiciera falta. El fin concreto es sólo llegar a describir y comprender, mediante los recursos gráficos legados por otros grupos humanos de la época con mentalidad parecida, la posible visión del cosmos que tuvieron algunas comunidades prehistóricas de la Península Ibérica, sobre todo aquellas que plasmaron en manifestaciones plásticas más o menos explícitas su imaginario celeste.

En este recorrido, se podrá observar la utilización de documentos que en principio parecen demasiado alejados entre sí, en tiempo y en espacio, como para servir de apoyo a la argumentación y a la interpretación. De hecho, algunas representaciones egipcias de época muy tardía ilustran con relativa facilidad composiciones calcolíticas de Europa occidental. Esta posible crítica metodológica, plausible si tratáramos algunos otros aspectos de la cultura, se suaviza al estudiar temas tan profundamente conservadores como la religión. Por eso se ha considerado lícito que, al analizar el disco de Nebra por ejemplo, se haya echado mano de imágenes del cosmos que distan mucho de la cronología del Bronce Antiguo atribuida a esa pieza alemana (Pásztor 2009: 80-81). En el caso concreto del mundo faraónico, sabemos que Nut, la divinización de la bóveda celeste y madre de los dioses, fue un concepto que apenas experimentó cambios durante casi todo el desarrollo de 
aquella cultura, pues estaba fijado en el tercer milenio a.C. con los caracteres básicos que mostrará hasta época romana. Por otra parte, no menos de tres mil años tiene la creencia humana en un dios que muere y resucita, y no por ello ha variado sustancialmente ni en sus detalles ni en su significado a lo largo de todo ese tiempo (Escacena 2007; 2009). La cuestión es de profunda importancia metodológica, pues afecta a la medida de los plazos temporales que en arqueología serían lícitos para su uso como espaciosmarco de referencia. En este sentido, la comprensión del presente trabajo requiere adoptar ritmos evolutivos no gradualistas, sino la existencia de segmentos cronológicos de quietud con larga duración (estasis evolutivas) seguidas de aceleraciones que producen el nacimiento casi repentino de nuevas situaciones, al modo propuesto por Eldredge y Gould (1972). Desde este enfoque saltacionista es lícito el uso como paralelos iconográficos de documentos separados entre sí por periodos de hasta tres mil años si el contexto mental que los originó ha permanecido relativamente estable durante ese tiempo.

\section{NAVEgación ASTRAL POR EL DISCO DE NEBRA}

El hallazgo en 1999 del llamado "disco celeste de Nebra", que ha tenido tanta acogida en obras de divulgación científica y en publicaciones especializadas (p.e. Meller 2004; Schlosser 2004), ha ofrecido una rica información sobre ciertos aspectos del pensamiento cósmico y religioso de algunas sociedades europeas de la primera Edad del Bronce (Meller 2002). Dicho objeto se encontró con motivo de unas rebuscas clandestinas en un yacimiento que se ha podido interpretar, gracias a los trabajos de campo posteriores, como un centro ceremonial. Su ambiente arqueológico se fecha en un momento relativamente temprano del segundo milenio a.C. (Meller 2004: 73; Pásztor y Roslund 2007: 267). La pieza, descubierta en la localidad alemana de Nebra (Sajonia-Anhalt), se trata, como indica su nombre, de un objeto discoidal elaborado en bronce, en el que se moldearon sobre una de sus caras diversos motivos astrales y otros temas de la cosmovisión prehistórica, todos ellos realizados mediante la incrustación de finas láminas de oro (fig. 1).

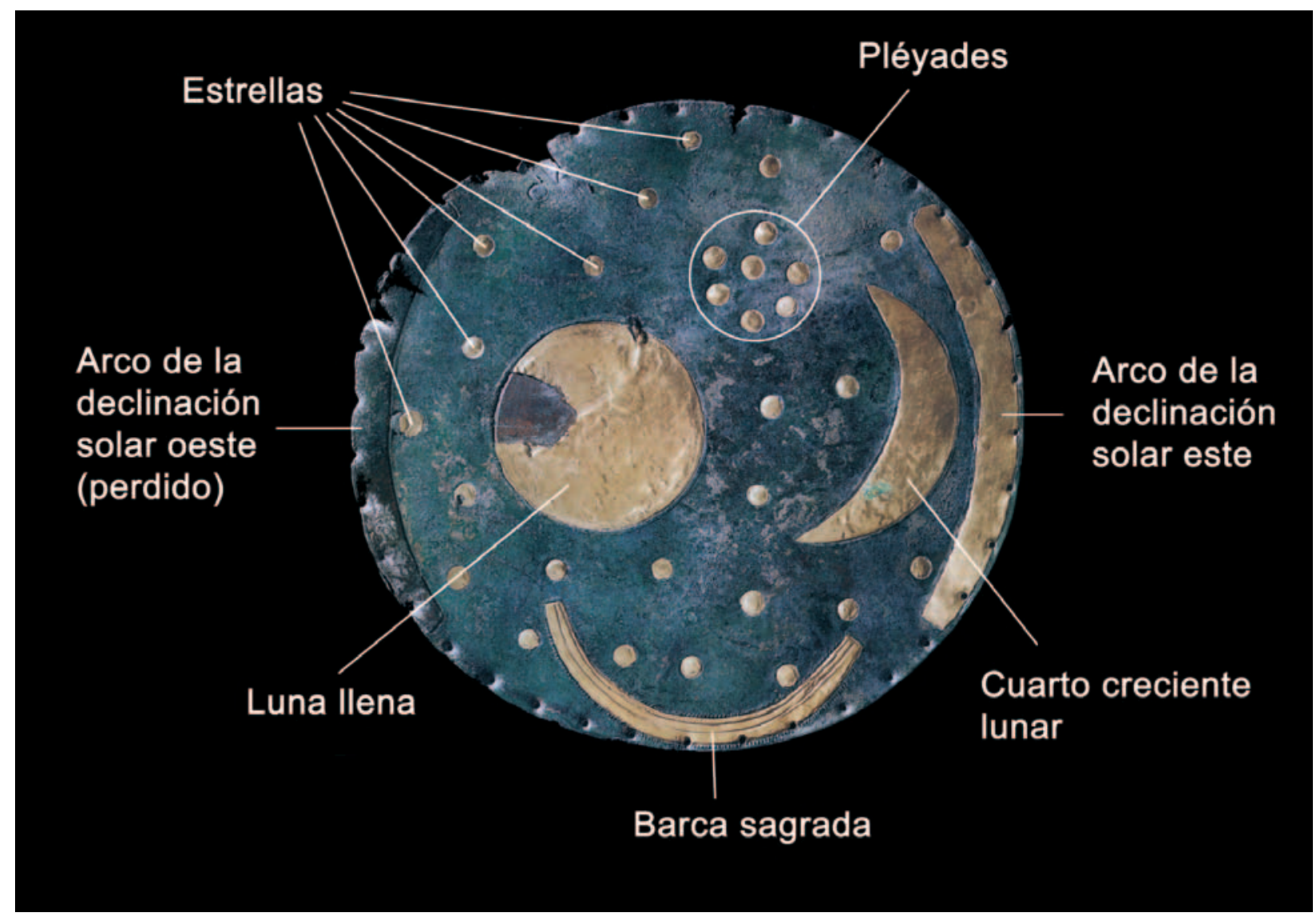

Figura 1. Interpretación tradicional del disco de Nebra. 
Para comprender el disco de Nebra se hacen imprescindibles unas mínimas reflexiones que fijen su correcta colocación de lectura, cosa que se ha pasado normalmente por alto al considerarse evidente la primera posición con que se dio a conocer. Es cierto que esta autopsia ineludible conduce a la misma perspectiva hoy aceptada por quienes lo han estudiado y publicado; pero, aún así, dicho examen explícito se hace por completo necesario si se pretende utilizar esta pieza como peldaño seguro en el posterior ascenso por la escala de la investigación. Más todavía si, como es el caso, para este uso como fuente de información se parte de una interpretación distinta de lo dicho hasta ahora acerca de los cuerpos representados en él, y por tanto también de su significado y de su simbolismo.

El disco celeste de Nebra cuenta con un elemento singular que trasciende la mera representación astral y que se adentra de lleno en la mentalidad religiosa de quienes lo elaboraron y usaron: la imagen esquemática de una barca sagrada. Se trata del arco que aparece definido por una lámina de oro recorrida por estrías paralelas casi tangentes. Dicho elemento no dispone de otro semejante en el flanco opuesto del círculo, y lleva en sus dos márgenes numerosos segmentos grabados sobre el propio bronce. Con razón, y gracias a los múltiples paralelos para este símbolo procedentes tanto del Mediterráneo como de la Europa nórdica, se ha reconocido aquí la imagen de una barca astral. De momento, no se ha ofrecido otra explicación más aceptable para tal emblema (fig. 2).

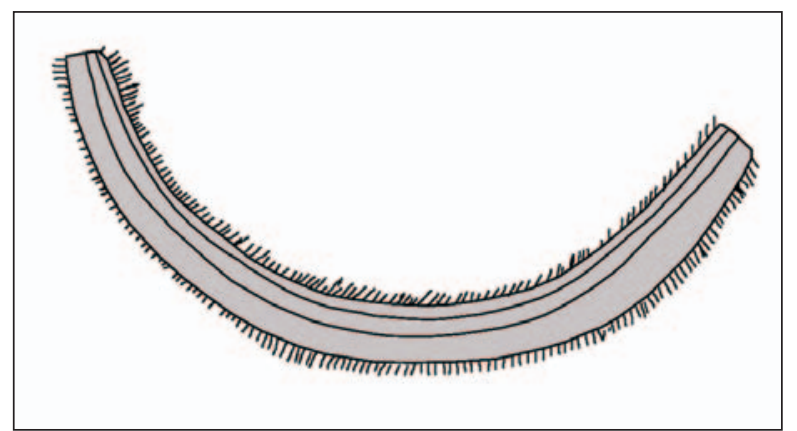

Figura 2. Imagen de la barca sagrada en el disco celeste de Nebra. Su representación se limita al casco de la nave, representado mediante un simple arco, y a los remos, que se indican con múltiples segmentillos a ambos lados.

\footnotetext{
3 Sin que necesariamente exista una relación directa de estas piezas cicládicas con el disco de Nebra o con los cuencos astronómicos hispanos analizados en el presente artículo, tal
}

Aceptado por tanto que estamos ante la imagen muy esquemática de una nave, es fácil asumir que las ligeras acanaladuras que la recorren a todo lo largo, paralelas a la borda, pueden ser representaciones de la tablazón, y que las numerosas estrías plasmadas arriba (parte cóncava) y abajo (parte convexa) del casco, que dan a la figura aspecto de milpiés, son simplemente los remos. Estos innumerables segmentillos estarían indicados aquí tan escuetamente como en los barcos de Siros (fig. 3). En estos últimos las palas se marcan a veces con simples puntos o con pequeñas hendiduras (Coleman 1985) ${ }^{3}$. En Nebra se combinaría la visión lateral para el casco del bote con la cenital para los remos, un recurso frecuente en representaciones artísticas prehistóricas que no dominan otras perspectivas. En consecuencia, la identificación de este motivo como barca sagrada obliga a colocarlo, para lograr una posición correcta de lectura, con su parte convexa hacia abajo, de la misma forma en que se representaría cualquier nave de casco curvo fuera ésta real o simbólica.

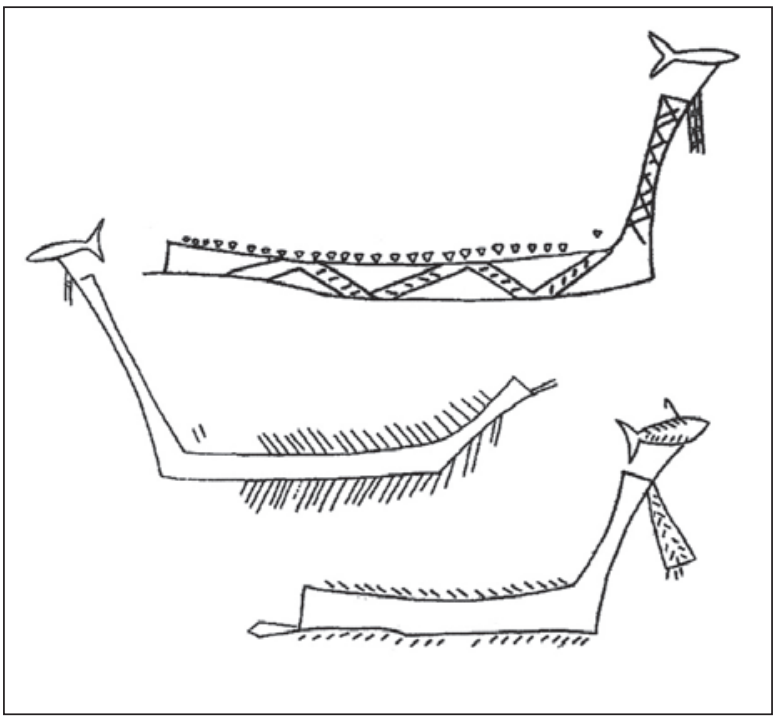

Figura 3. En los barcos de Siros los remos llegan a ser también unas líneas elementales que parten de las bordas.

Una vez establecido con seguridad el punto de vista apropiado para el análisis -el inverso aludiría a una embarcación boca abajo y por tanto zozobrada- se pueden despejar otras incógnitas para proceder a una interpretación adecuada de la

vez no sea casual que las denominadas "sartenes" de Siros estén decoradas en unos casos con navíos y en otros con estrellas. 
pieza. Así, los dos arcos dorados que limitan de forma simétrica el disco a izquierda y derecha -uno de ellos ha perdido la lámina de oro-, que no parecen ser la representación de ningún objeto celeste, sólo pueden leerse como expresiones de la declinación, sobre los horizontes este y oeste, de los astros personificados en la zona central del círculo, cualesquiera que éstos sean.

El disco de Nebra se tiene normalmente por una plasmación del cielo durante la noche, sobre todo al dar por estrellas todos los puntos pequeños. Al unir a esa lectura la idea de que la Luna estaría presente dos veces, las implicaciones que nuestro satélite siempre tuvo para la organización de los meses han llevado a proponer que dicho objeto es también una suerte de calendario agrícola (Schlosser 2004). La hipótesis de la foto nocturna, ya tradicional a pesar de su juventud, se basa en la necesaria identificación como estrellas de los circulillos del anverso, que en buena lógica no deberían aparecer en una imagen diurna si efectivamente lo fueran. Sin embargo, las estrellas nunca fueron simples puntos en el arte occidental de la Prehistoria reciente; tampoco en las imágenes del cielo o en las escrituras arcaicas del Próximo Oriente asiático o de Egipto. De ahí que sea posible otra lectura para estos círculos más numerosos. Esto deja libre el camino a una nueva interpretación que quiera ver en la pieza un cuadro sólo simbólico de la bóveda celeste. El mismo hecho de que los remos de la barca cósmica estén marcados en cantidad desproporcionada si comparamos la imagen con cualquier embarcación real, revelaría de nuevo el mero carácter imaginario del objeto.

En la premisa, tal vez errónea, de estar ante una escena nocturna, no ha habido más remedio que leer los objetos centrales como astros visibles durante la noche. Por eso mismo, y dada la evidente identificación de uno de esos cuerpos con la Luna en cuarto creciente, el elemento circular de la parte central izquierda sólo podría representar a nuestro satélite en fase de plenilunio, porque el Sol debe estar por fuerza ausente de una foto nocturna del cielo. De esta forma, y siempre según esta primera y más aceptada interpretación ya clásica, la Luna aparecería dos veces. Para esta hipótesis, la agrupación de puntos pequeños de la parte superior derecha debería ser obligatoria- mente alguna constelación, ya que esos pequeños circulillos se creen estrellas. Por eso, la lectura hasta ahora dominante ha visto en este conglomerado de puntos a las Pléyades (Schlosser 2002; Pásztor 2009: 81), que hacia el 1600 a.C. eran visibles en la noche alemana a la latitud del lugar del hallazgo. En cualquier caso, se ha precisado que la posición de las Pléyades para un observador ubicado en Nebra en esa época no sería exactamente la misma que muestra el disco (Pásztor y Roslund 2007: 270), con lo que esta pertinente observación apoyaría de nuevo la idea de estar ante un objeto puramente simbólico.

Pero esta exégesis del disco de Nebra, ya habitual, muestra diversos flancos débiles. Por tanto, su crítica puede ofrecer campo abonado para una interpretación distinta que los evite. En cualquier caso, la nueva hipótesis aquí propuesta parte de la coincidencia con la anterior en una identificación correcta de la barca sagrada, simplemente porque no hay otra alternativa más plausible. Para entenderla en sus justos términos, conviene señalar antes algunas cuestiones técnicas de la fabricación del disco, lo que puede ayudar a su mejor comprensión.

Quien lo fabricara se vio en la necesidad de grabar sobre la superficie de bronce una serie de líneas curvas a la hora de plasmar la silueta de los elementos representados, incisiones que servirían para embutir y sujetar allí los márgenes de las láminas de oro correspondientes a los distintos cuerpos celestes. Como los objetos mayores elaborados de esta forma están diseñados con arcos o circunferencias de distinta apertura, de manera que forman elementos de límites curvos con tamaños distintos, para marcar su contorno el artesano no pudo repetir la acción de troquelado con una misma matriz que produjera siempre acanaladuras circulares con idénticos diámetros. Sin embargo, los puntos pequeños sí podían resolverse mediante impresiones reiteradas de una sola herramienta que dejara en todos los casos una marca similar en forma de circunferencia. Esta simplificación del proceso de trabajo ha podido originar cierta confusión en la interpretación de dichos círculos diminutos, en el sentido de que ha llevado siempre a creer que todos ellos representan lo mismo, en concreto estrellas en una pano- 


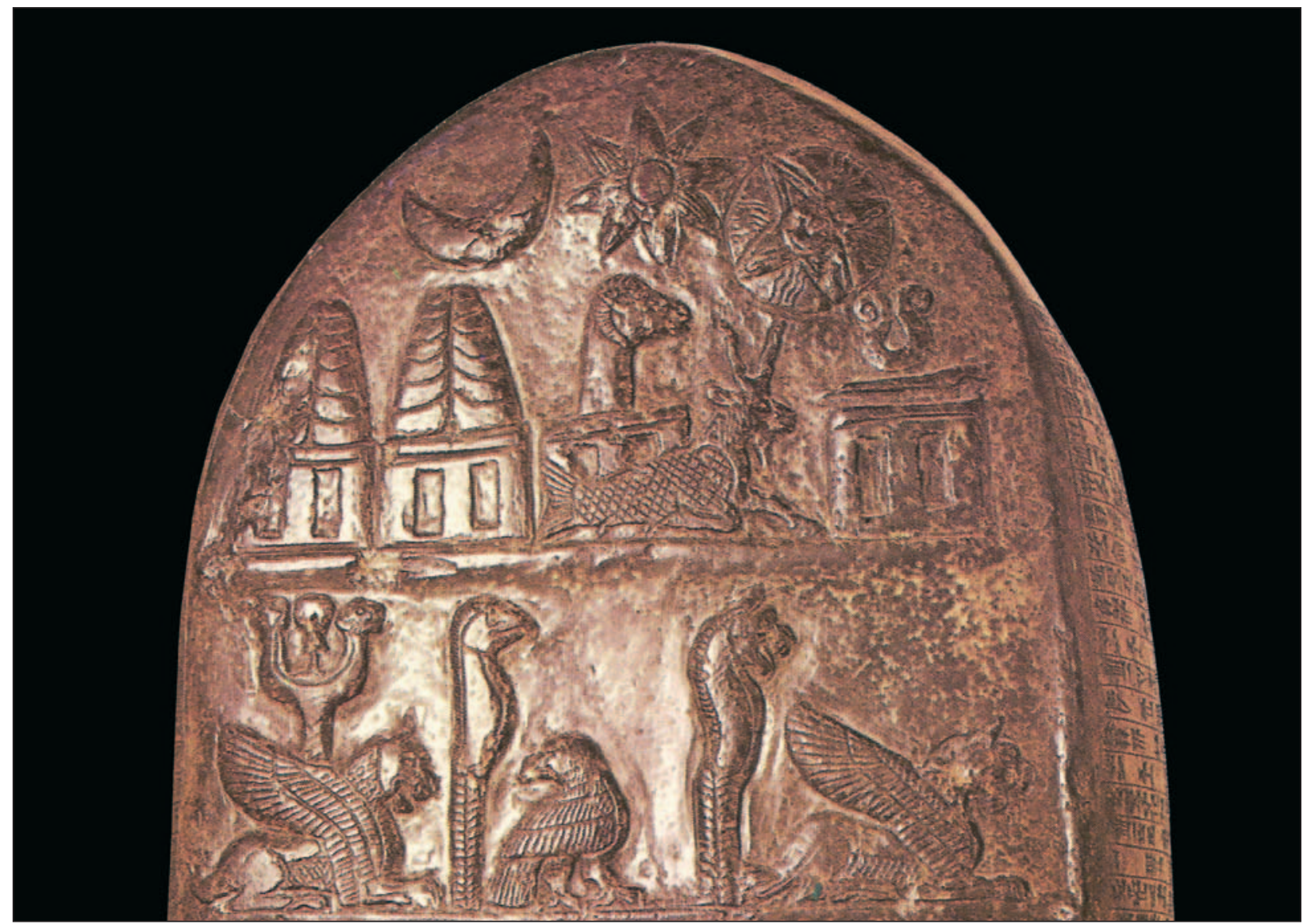

Figura 4. Detalle de la parte superior del kudurru de Melishipak (Museo del Louvre). Comienza la composición con las imágenes del Sol (Shamash), que preside la escena en el centro, la Luna (Sin), a la izquierda, y Venus (Ishtar), a la derecha.

rámica nocturna. Pero la solución técnica del artesano, destinada a un simple ahorro de trabajo, no puede obligar a esta asimilación automática en la que todo punto sea una estrella. Por ello, es viable proponer una interpretación diferente de la asumida hasta ahora para la nube de circulillos interpretada como las Pléyades. Igualmente, puede avanzarse otra lectura, también distinta de la tradicional, para el resto de los puntos. En cualquier caso, para la hipótesis aquí desarrollada estos pequeños círculos nunca corresponderían a estrellas, lo que libera a la nueva lectura de tener que trabajar por fuerza con una figuración de la noche, ni real ni imaginada.

Muchas culturas antiguas del Mediterráneo pensaron en un mundo de dioses astrales presidido por tres entes. De hecho, los kudurru mesopotámicos y otras estelas de las civilizaciones del Oriente Próximo encabezaron los textos o las narraciones figurativas que contenían con la representación de tres cuerpos celestes: el Sol, la
Luna y Venus (Seild 1989: lám. 19 ss.). Se trata en realidad de representaciones divinas invocadas al principio mediante sus iconos (fig. 4). Estas mismas tríadas aparecen también en culturas no asiáticas, por ejemplo en vasijas del mundo griego (fig. 5). Para la mentalidad y la tecnología de la época, el Sol y la Luna eran los astros de mayor tamaño, los más cómodos de observar y los que disponían de movimientos regulares predecibles más fáciles de medir. Por eso fueron los cuerpos celestes de presencia más incuestionable en nuestro entorno cósmico inmediato, hasta el punto de que el precoz conocimiento de sus derroteros astronómicos ayudó a la elaboración de calendarios tempranos con los ciclos de ambos astros e incluso al desarrollo de la matemática (Robins 1995: 1811). Mientras el Sol ofrecía mayor exactitud en la medida del periodo anual, la Luna brindaba la posibilidad de dividir todo el año en segmentos, agrupaciones de días que dieron lugar a los meses. 


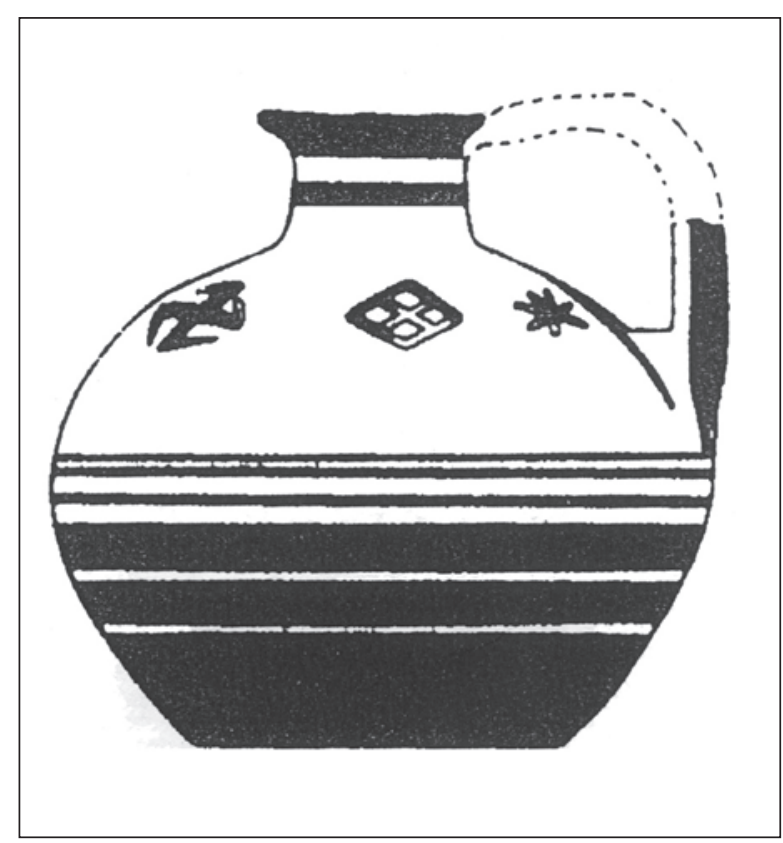

Figura 5. Vaso griego que muestra la secuencia (de izquierda a derecha) "Sol-Luna-Venus".

La representación del Sol como esvástica (aspa giratoria) es común entre los indoeuropeos prehistóricos, por ejemplo en el mundo celta.

Más rara es la imagen de la Luna como un cuadrado dividido en cuatro partes alusivas a sus fases.

En cambio, es muy frecuente el asterisco para Venus.

A pesar de que el Sol y la Luna constituyen cuerpos astronómicos omnipresentes en las culturas antiguas mediterráneas, por lo común las tradiciones teológicas orientales no hicieron de la Luna y el Sol un matrimonio divino. Si bien dentro de una escuela religiosa tardía, algunos textos egipcios nombran a ambos astros como ojos de un mismo numen creador y providente (Lull 2004: 35), pero no como los dos polos -masculino y femenino- de una misma pareja sagrada. El hecho de que desde la Tierra se vean a veces en puntos opuestos desaconsejó tal enlace. Si el astro rey necesitaba un cónyuge, el mejor candidato era sin duda Venus.

Mercurio y Venus son planetas cercanos al sol; definen así órbitas más cortas. De esto se tenía ya constancia en el mundo egipcio, por lo que se representaron allí los planetas conocidos entonces agrupados en dos lotes: Marte, Júpiter y Saturno por un lado y Mercurio y Venus por otro (Lull 2004: 185). Desde nuestra posición en el sistema solar, los planetas interiores aparecen por tanto con los índices menores de elongación. El más próximo al Sol es Mercurio, con un valor máximo de $23^{\circ}$, mientras que Venus presenta hasta $44^{\circ}$ en su mayor separación del globo solar (Kragh 2008: 56). Pues bien, como para la mentalidad antigua -y para muchas culturas actualesla esposa debe ser fiel seguidora del marido, Mercurio y Venus constituían, en calidad de astros siempre cercanos al Sol, los mejores candidatos a erigirse en su adecuada compañera. Por su mayor separación de la Tierra, pero sobre todo por su menor tamaño, Mercurio contaba con menos posibilidades para desempeñar ese papel, más que nada porque esos rasgos lo dotan de un brillo menos intenso que el de Venus aun pudiéndose observar a ojo desnudo. Visto desde la Tierra, Venus representa de hecho el planeta interno más luminoso. Por ello venció a Mercurio y acabó convertido también en diosa del amor y de la fecundidad, con distintos nombres según los contextos culturales y lingüísticos en los que se le reconoció este papel. Por el contrario, y siguiendo un destino mítico distinto, Mercurio desembocó justo en el cometido opuesto. Representó así el perfil del mal, en Egipto encarnado en Seth como numen perverso y como hermano envidioso asesino de Osiris (Lull 2004: 183).

Asumir que el disco de Nebra pueda exhibir la tríada astral y divina Sol-Luna-Venus resulta por tanto una hipótesis viable. Pero verificarla exige encontrar entre los elementos representados la imagen del planeta Venus, condición sin la cual la nueva interpretación debe descartarse a pesar de las debilidades y contradicciones de la anterior. La lectura propuesta aquí parte de que no estemos necesariamente ante una foto nocturna, sino ante una representación ideal de la bóveda del firmamento al modo como la entendieron las culturas antiguas. Se indicarían incluso algunos de los movimientos que, desde la perspectiva terrestre, caracterizan a los cuerpos celestes representados. Son los arcos que definen los acimutes de ortos y ocasos astrales en los flancos izquierdo y derecho del conjunto. Tampoco sería el disco de Nebra, por tanto, un instrumento de precisión para tomar medidas astronómicas (González García 2004). A partir de estas consideraciones, puede darse por cierta la representación, a la derecha de la parte central, del cuarto 


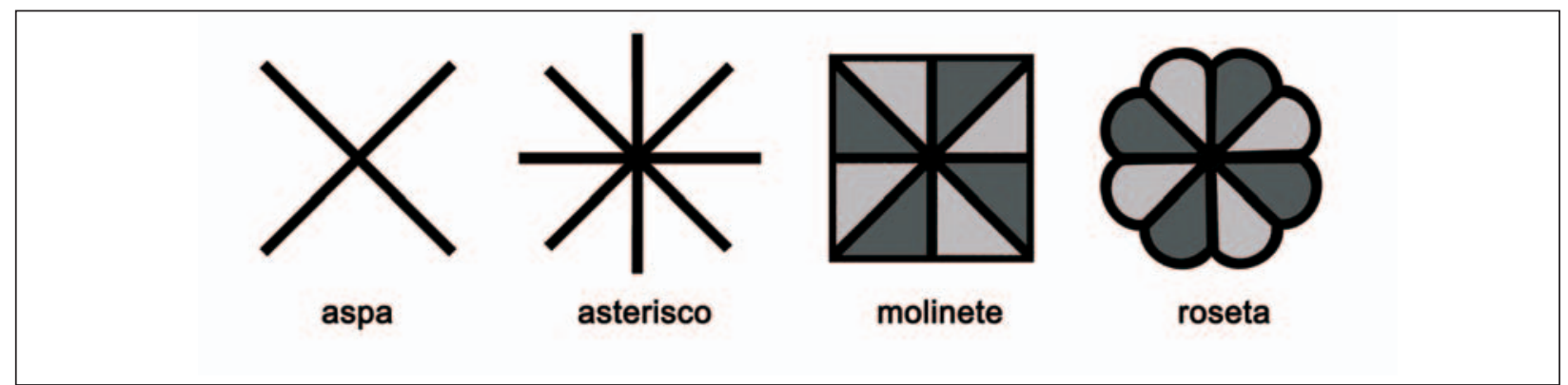

Figura 6. En las vasijas hispanas de época tartésica Venus se representó como estrella con diversas formas, desde las más elementales (aspa y asterisco) hasta las más complejas (molinete y roseta).

creciente lunar, acompañado por el Sol a su izquierda. De esta forma el planeta Venus quedaría materializado en la agrupación de puntos tenida hasta ahora por las Pléyades.

La alusión gráfica a un astro mediante un conglomerado de pequeños círculos, presidido por uno de ellos que ocupa el centro y que sólo a veces puede ser el mayor de todos, se conoce en el Próximo Oriente asiático desde momentos relativamente antiguos, al menos desde el segundo milenio a.C., en fechas por tanto cercanas a la cronología de 1600 a.C. aceptada para el disco de Nebra. Algunas veces se usó como icono geométrico asociado a la roseta, enseña por antonomasia de la patrona del amor especialmente frecuente en el mundo de los semitas asiáticos occidentales, los cananeos entre otros. Expresada con puntos, con pétalos o mediante una combinación de ambos elementos, la roseta llegó a ser insignia de la diosa madre mediterránea (Kukahn 1962: 80), expresión gráfica de su hie- rofanía astral e imagen de la Astarté fenicia en tanto que Lucero (Escacena 2011: 177 y 191) y reina del cielo (López Monteagudo y San Nicolás 1996: 452), título que se le adjudica en un pasaje de la Biblia hebrea (Jeremías 7, 18 y 44). Los vínculos entre dicho emblema y la Ishtar mesopotámica o la Astarté fenicia están libres de toda duda. Es más, a pesar del nombre arqueológico del motivo, que parece asimilar su forma al mundo vegetal, la roseta no es la imagen de una flor aunque la diosa del amor sea también protectora de la fecundidad de las plantas; es un blasón astral evolucionado a partir del trazado elemental de un asterisco que cerrara los campos abarcados por sus rayos (fig. 6). De ahí que en algunas imágenes griegas aparezca centrada sobre un campo de estrellas, como un objeto celeste más (fig. 7). Por ello, la iconografía antigua combinó a veces la roseta con la nebulosa de puntos, como puede observarse en joyas micénicas y cananeas, y mucho más tarde en el

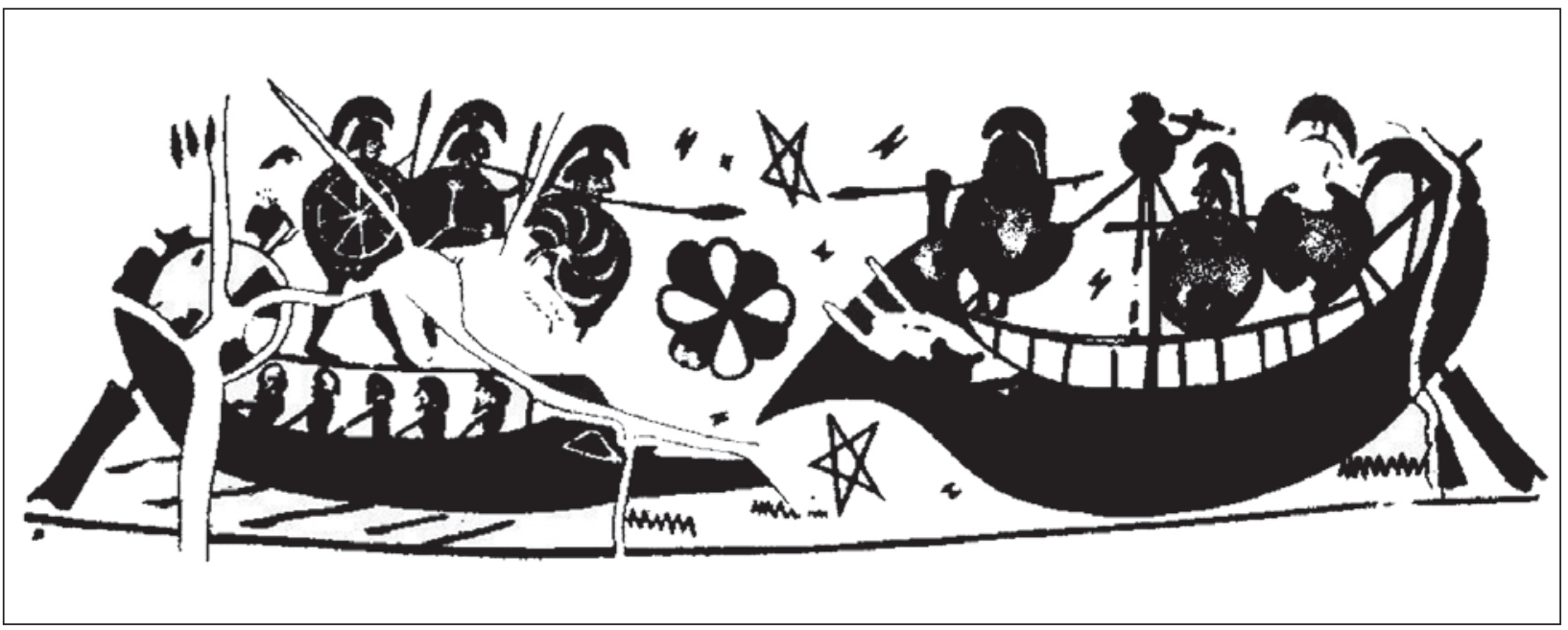

Figura 7. Batalla naval representada en un vaso griego. Venus aparece en el centro de la escena como una roseta sobre un campo de estrellas fijas más lejanas. 


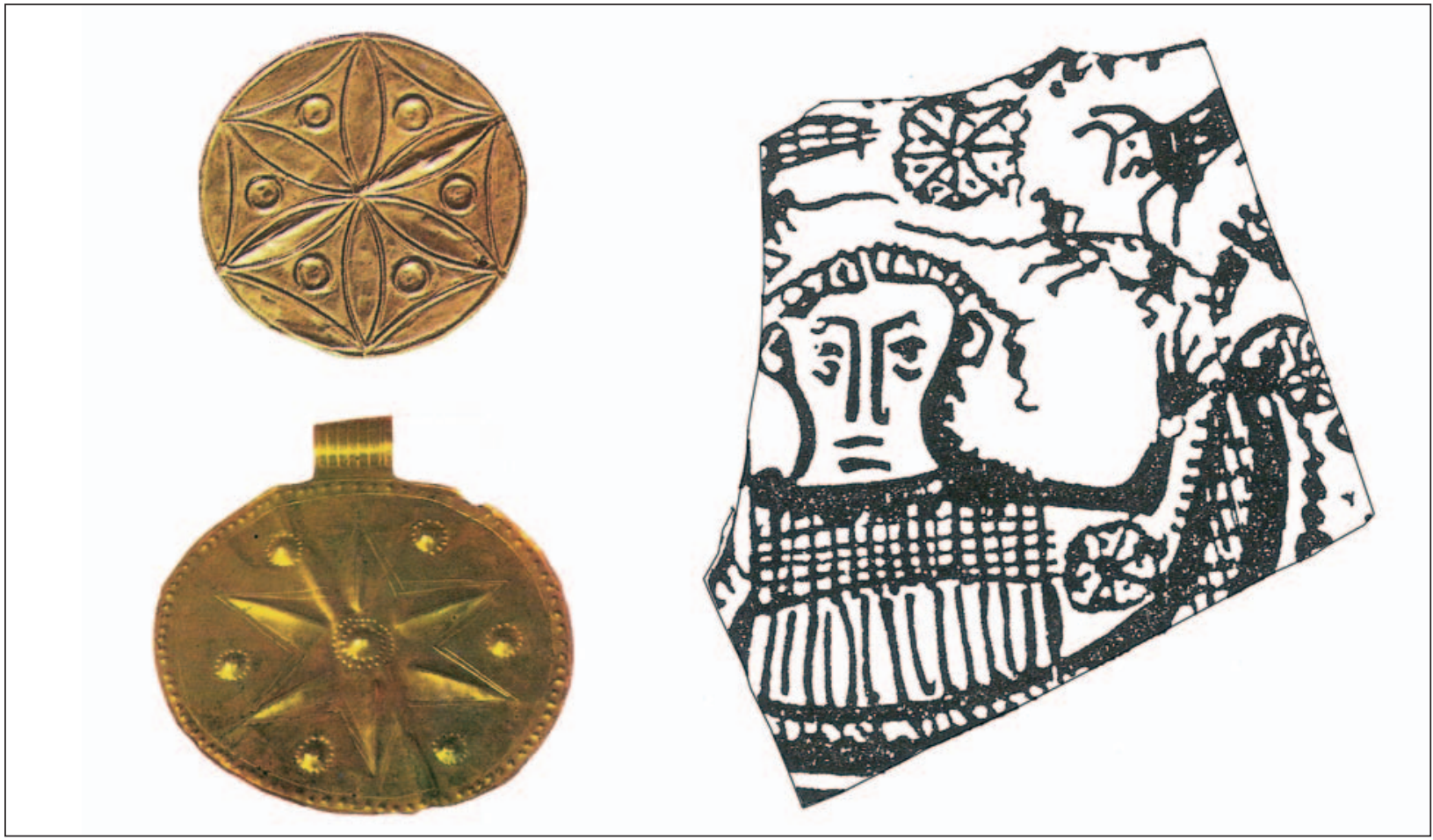

Figura 8. Diosa sobre su barca astral (derecha). Se insiste en su identificación con el planeta Venus mediante la colocación de rosetas con sus pétalos-rayos y el correspondiente grupo de puntos asociado.

Se trata de la misma composición de algunas joyas micénicas (parte superior izquierda) y cananeas (parte inferior izquierda). Las piezas de orfebrería demuestran que esta imagen más o menos canónica del planeta Venus estaba ya fijada en el segundo milenio a.C.

mundo prerromano de la Península Ibérica (fig. 8). Con el diseño exclusivo de lunares o semiesferas en torno a un círculo interno, representaciones astrales con este diseño ocuparon el centro de frescos parietales en algunos palacios asirios (fig. 9), pero de esta misma forma se conoció previamente también en la orfebrería micé- nica (fig. 10). En su expansión hacia el oeste, la diáspora fenicia del primer milenio a.C. llevó ese viejo icono venusino hasta el suroeste de la Península Ibérica, donde uno de los testimonios más arcaicos es sin duda el cuenco aparecido en el yacimiento conocido como Carambolo alto (fig. 11). En este cabezo de la paleodesemboca-

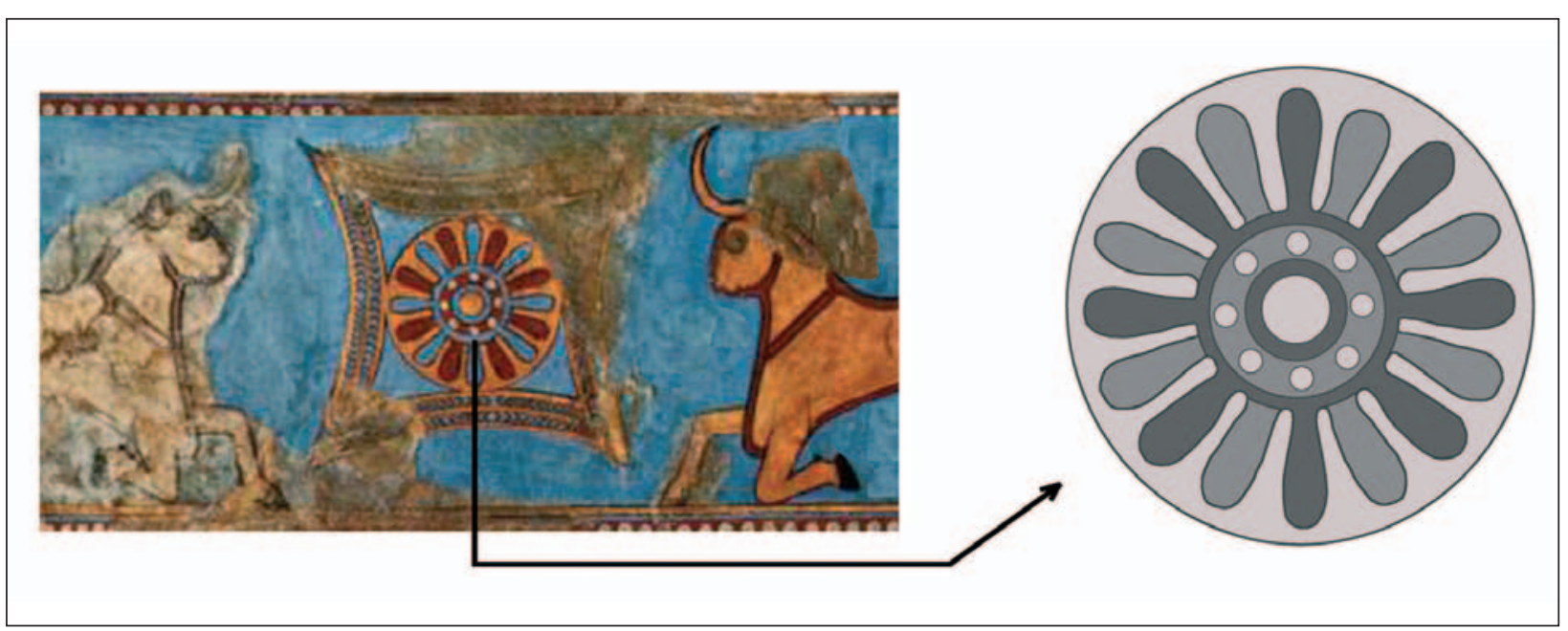

Figura 9. Altar taurodérmico en un fresco palacial asirio, ante el que se arrodillan dos toros.

El hogar está decorado con una gran roseta de múltiples pétalos que lleva en su centro el típico conglomerado de puntos como posible representación astral, en este caso presidido en el centro por uno de mayor tamaño. 


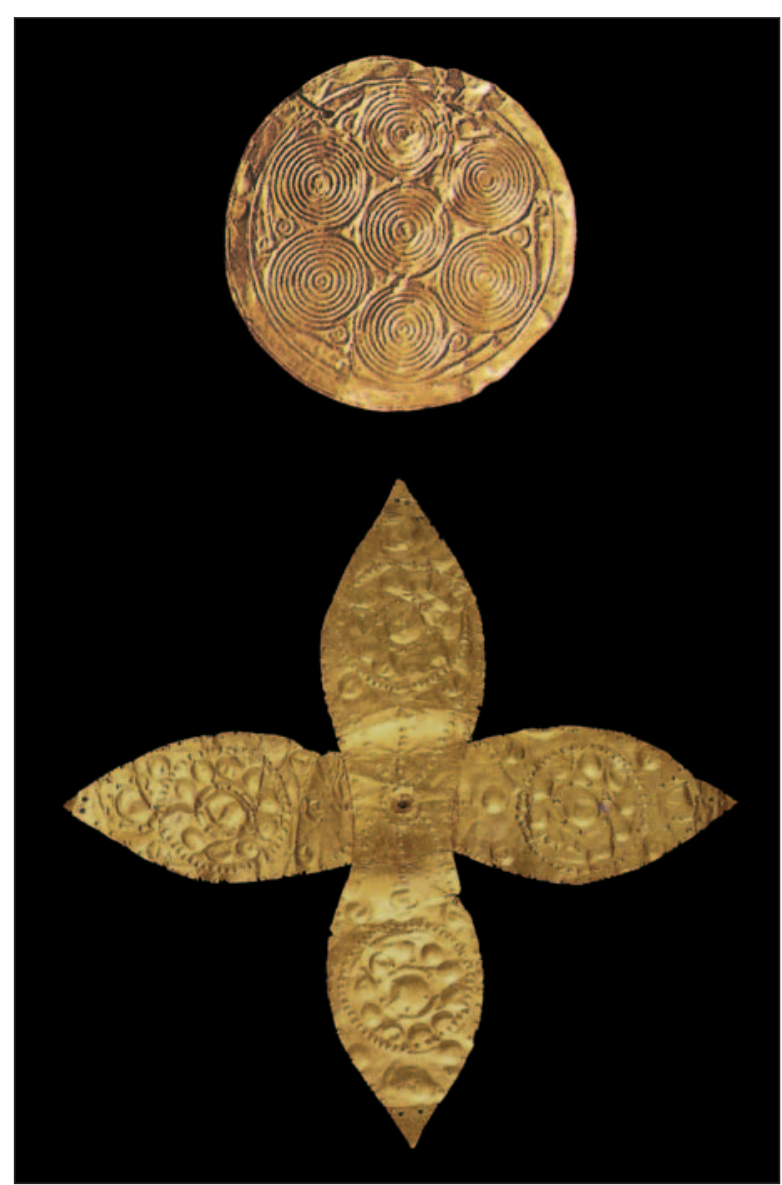

Figura 10. Joyas micénicas donde las representaciones astrales se limitan a grupos de puntos dispuestos alrededor de uno central, que en algún caso puede ser más grande (abajo). En la pieza superior las puntuaciones se elaboraron mediante espirales, recurso gráfico habitual durante el segundo milenio a.C. en el Egeo.

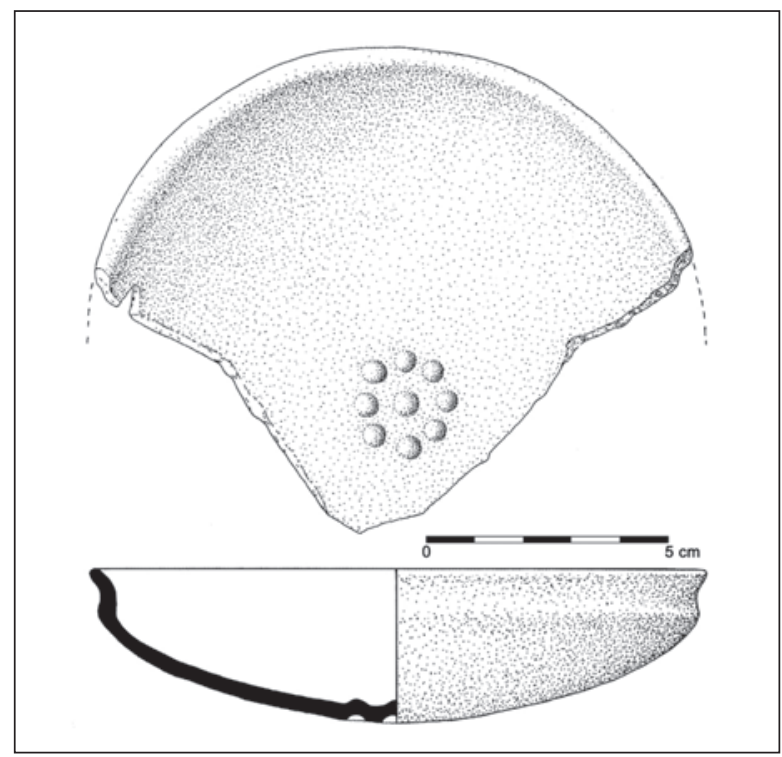

Figura 11. Icono de Astarté como astro de bullones en relieve. Cuenco cerámico del santuario fenicio ubicado en El Carambolo. dura del Guadalquivir, los colonos semitas levantaron un santuario a Astarté a la vez que fundaban la colonia de Spal, hoy la ciudad de Sevilla. Igualmente, otras culturas prehistóricas mediterráneas representaron más o menos con esta forma algunos de los astros más importantes del sistema solar. En muchos de estos casos no existe certeza sobre el cuerpo celeste aludido, pero sí puede deducirse de esas imágenes que se trata de un único objeto, no de una constelación. Ello se deduce de la alta frecuencia con la que los grupos de puntos aparecen enmarcados en círculos, como ocurre en el petroglifo onubense de los Aulagares y en otros grabados rupestres asociados al mundo megalítico (Del Amo 1974: fig. 1-18; Linares 2011: 177-193). Este preciso diseño sugiere que todo el conjunto debe interpretarse como alusión a una sola entidad (fig. 12).

En esta nueva hipótesis queda por saber la razón por la que se plasmó de esta forma peculiar al planeta-diosa Venus. De hecho, en otras ocasiones se le representó con la silueta convencional y más simple de una estrella, es decir, mediante un cuerpo que emite haces de rayos, según se aprecia por ejemplo en los ya citados kudurru mesopotámicos. Averiguar la razón básica de esta particular iconografía constituye en realidad un aspecto marginal para la presente interpretación. Puede ser oportuno, en todo caso, proponer para futuras investigaciones que, mediante este diseño, se pretendió recoger la luz irregular de Venus mediante puntos que se encienden y se apagan en una secuencia intermitente y aleatoria, una característica óptica que puede tener su correlato literario en el nombre recogido para el Lucero (Phosphóros) por Estrabón (III 1, 9). Al referirse a la divinidad adorada en el santuario gaditano dedicado a Venus en la Algaida con el nombre de lux dubia, se estaría aludiendo a luz dudosa o incierta, crepúsculo para algunos (Tovar 1962: 814) o también aurora (Marín 2011: 506), o tal vez simplemente luz parpadeante o dubitativa, en el sentido de luminosidad no fija ni continua. Es una realidad que el brillo de los planetas, reflejo del resplandor solar, suele centellear cuando éstos se encuentran cerca de la línea del horizonte, lo 

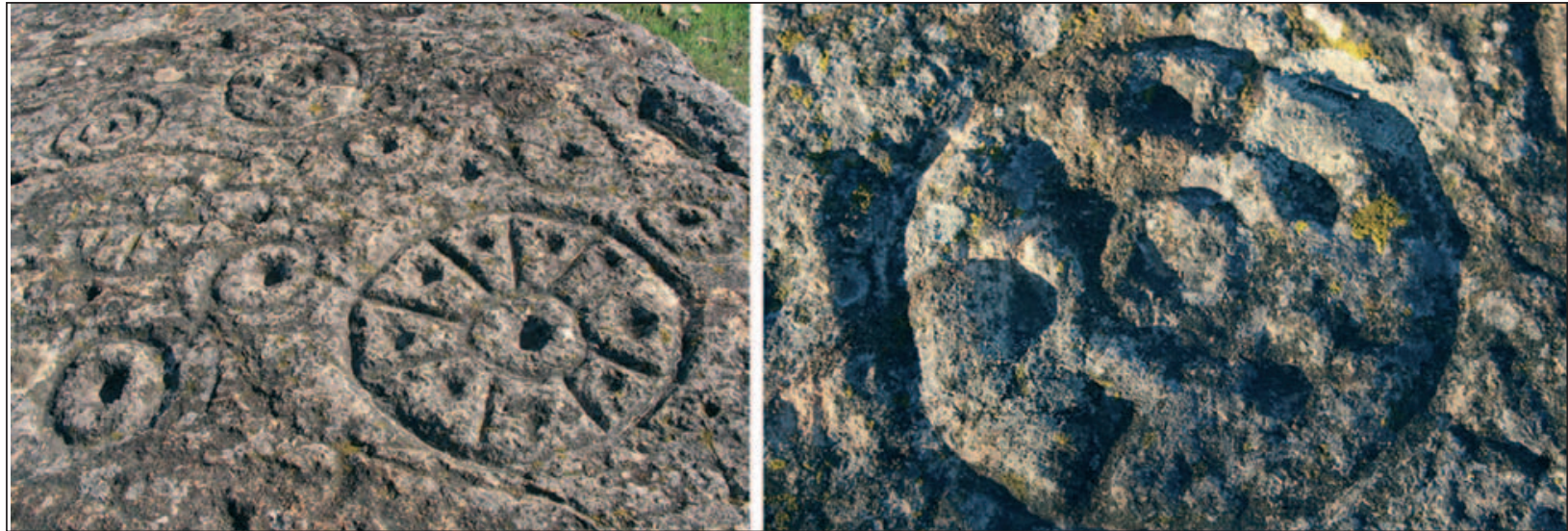

Figura 12. Petroglifo de Los Aulagares con varias representaciones astrales expresadas como nubes de puntos. El hecho de que esos pequeños huecos redondos vayan enmarcados en círculos parece aludir a que forman en conjunto un solo cuerpo celeste. Ello demostraría que no expresan constelaciones.

que se debe a la reverberación atmosférica. Este rasgo concreto ha sido señalado en algunas observaciones de Venus, que hablan precisamente de agrupación de puntos destelleantes ${ }^{4}$.

Una vez identificada en el disco de Nebra la tríada Sol-Luna-Venus, la nueva hipótesis se ve obligada a concretar qué sean los pequeños puntos esparcidos al azar por el conjunto de la composición, aquellos que no forman un conglomerado especial como el que define a Venus. Para ello, debe rechazarse además, y de forma previa, la idea de que el disco suponga la materialización de un instrumento de medición astronómica. Esta posibilidad ha sido barajada alguna vez, aunque más desde trabajos de escaso nivel científico que desde publicaciones especializadas. Se basa en la presencia de las dos chapas curvas laterales y simétricas alusivas a los recorridos, sobre los horizontes este y oeste, de uno de los astros que aparecen en la zona central. Dichos arcos marginales deberían corresponder a la declinación lunar en la hipótesis de que el cuerpo plasmado en el centro fuese sólo la Luna en sus fases de cuarto creciente y de plenilunio. Pero, además de que los lunasticios no coinciden con los límites de estas figuras arqueadas del disco, dichas posiciones lunares extremas sólo acontecen cada 18,6 años, lo que hace de ese fenómeno un caso mucho más

4 Comunicación oral de César Esteban, a quien agradezco la referencia.

5 Los lunasticios se denominan también paradas mayores. Son fenómenos parecidos a los solsticios (Aparicio y otros 2000: 33-34; Aveni 1991: 88-89). infrecuente que el solsticio anual y por tanto tal vez menos digno de recoger en este objeto si hubiese servido como calendario anual ${ }^{5}$. Tampoco obedece la apertura angular de esos elementos curvos laterales a los venusticios, a lo que debe añadirse en este caso la complejidad de los movimientos y posiciones relativas de Venus en relación con la Tierra. De hecho, las situaciones de este planeta parecidas a los solsticios y a las paradas mayores de la Luna sólo son observables desde nuestro planeta cada cinco periodos sinódicos de Venus, que equivalen a ocho años terrestres ${ }^{6}$. De nuevo parece estar lejos de las intenciones del disco de Nebra señalar este tipo de fenómeno de ciclo no anual. Finalmente, los extremos de los arcos no corresponden tampoco con la posición esperada para los solsticios, por lo que no estarían aquí reflejados con exactitud los desplazamientos solares sobre los horizontes este y oeste.

El resultado de todas estas precisiones es el necesario rechazo de la interpretación del disco de Nebra como instrumento de medición astronómica o como almanaque lunar. Por eso la explicación simbólica resulta la más verosímil. En ella cabría leer esos elementos curvos laterales como arcos de acimutes de ortos y ocasos astrales, y por tanto llegar a la conclusión de que en la Europa

6 Venus describe una vuelta completa alrededor del Sol en algo menos de 225 días (periodo sidéreo). Para un observador terrestre, cada 584 días (periodo sinódico) el planeta ocupa la misma posición respecto al Sol (Sprajc 1996: 17-29 y 139-153). 
del Bronce Antiguo se conocía el fenómeno de la declinación ${ }^{7}$. Pero, al no responder los extremos de esos arcos a los límites máximos de las declinaciones concretas de ninguno de los cuerpos celestes que pueden estar representados en el círculo de bronce, deberá concluirse de nuevo que no hay en ellos ningún afán de precisión, sino sólo la alusión alegórica a que los astros-dioses referidos cuentan con secuencias cíclicas de posiciones extremas en el horizonte oriental durante sus ortos y en el occidental durante sus ocasos. Por eso los arcos de acimutes de ortos y ocasos del disco de Nebra tienden en realidad a dividir toda la circunferencia del mismo en cuatro sectores equivalentes (Pásztor y Roslund 2007: 271), como si se quisiera expresar con ello la división del mundo, concebido como plataforma circular, en cuatro partes iguales. Esa concepción cuatripartita de la superficie terrestre era una constante en muchas culturas del Mediterráneo arcaico.

Al abandonar la idea de imagen nocturna del cielo de la Alemania prehistórica, la hipótesis de que el disco de Nebra sea una mera representación de la bóveda celeste tal como ésta se pensaba en la época cobra mayor fuerza. Pero, sobre todo, permite trabajar con un recurso metodológico nuevo para acceder a su interpretación: la comparación con otras imágenes similares del cosmos elaboradas por culturas antiguas, en muchos casos más explícitas. En este sentido, las representaciones más elocuentes proceden del Egipto faraónico.

En país del Nilo, las visiones del firmamento fueron el producto de diversas tradiciones cosmológicas que diferían en aspectos relativos al modo de comienzo del universo (Lull 2004: 19-38). A la hora de interpretar sus observaciones astronómicas, los sacerdotes de las distintas escuelas teológicas coincidieron sin embargo en concebir un mundo terrestre, el dios Geb, de forma circular. Toda su extensión estaría cubierta por una bóveda estrellada, la diosa Nut (fig. 13). Las imágenes de la época muestran el cuerpo de la diosa combado para dar la impresión de una cúpula. Las más

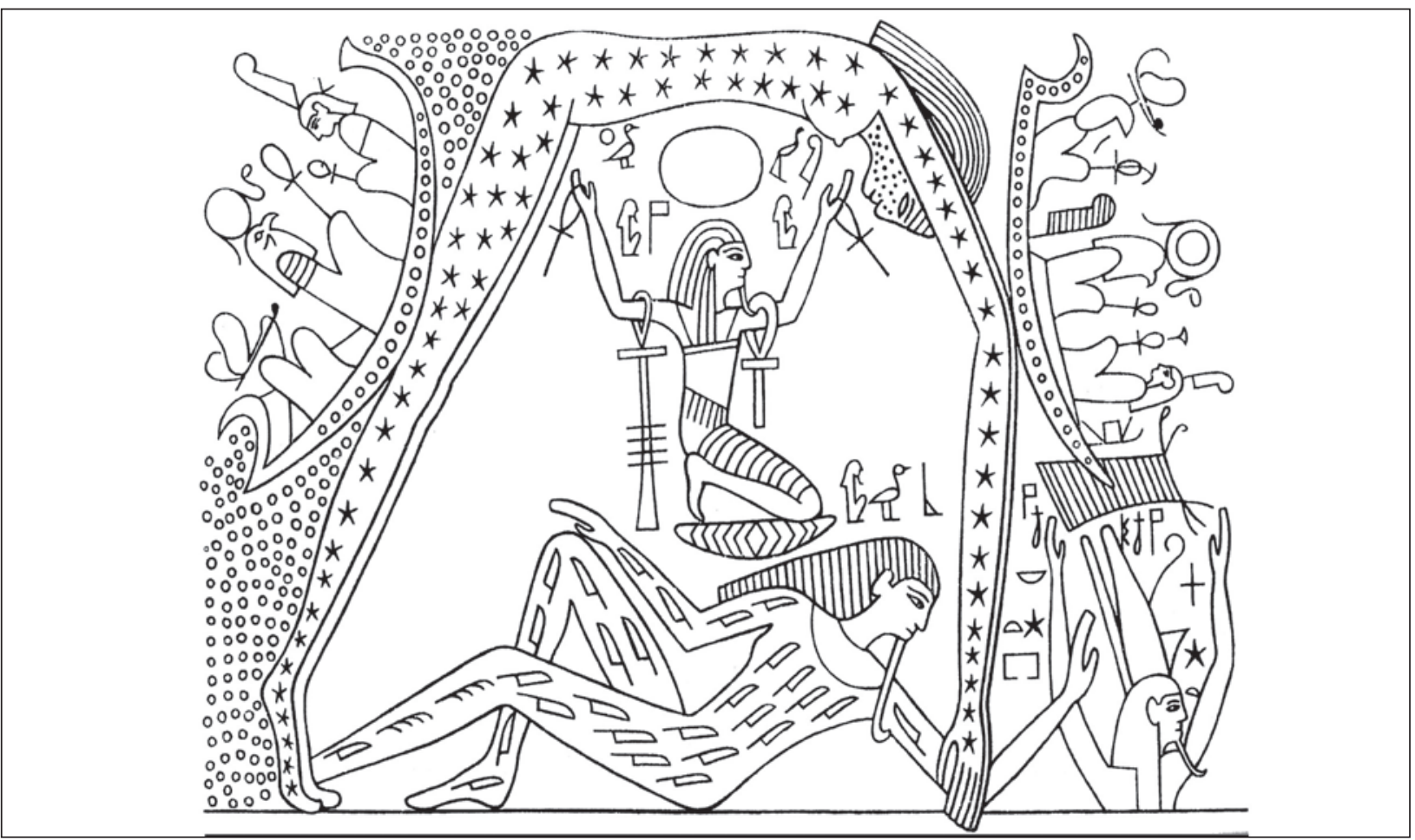

Figura 13. Visión egipcia del mundo, con el dios Geb (Tierra) recostado en la parte inferior y la diosa Nut (bóveda celeste) como límite superior cóncavo del firmamento. En los cielos navega el Sol sobre su barca sagrada desde el este (izquierda) hacia el oeste (derecha).

7 Que se tenga registrada la declinación, e incluso medida, no presupone su comprensión. Muchos siglos después, todavía Heródoto (II 24, 1-2) atribuía al viento del norte el despla- zamiento del Sol en dirección meridional, hasta alcanzar la Alta Libia (África del Norte) durante el solsticio de invierno. 
explícitas exhiben además barcas astrales que navegan por las aguas del firmamento, las que el demiurgo colocó sobre la bóveda celeste al crear el universo y separar la masa acuosa primordial y caótica (Nun) en dos partes. Esta visión del cosmos tenía una buena razón lógica, ya que la experiencia humana de la lluvia lleva a pensar en la existencia de agua en el cielo. Y, como esas aguas caen a la superficie terrestre en forma de gotas esféricas, su representación se llevó a cabo casi siempre de forma distinta a la de las aguas marinas y fluviales, materializadas en este último caso como una sucesión de líneas onduladas. De ahí que las barcas sagradas, sobre las que se desplazan por el espacio acuoso del firmamento los dioses-astros, naveguen en ocasiones por un piélago de puntos diminutos. En consecuencia, si no son necesariamente estrellas los pequeños circulillos dorados del disco de Nebra, lo más probable es que representen, en distribución aleatoria por casi toda su superficie, el agua situada por encima del firmamento. Pequeños círculos se incluían de hecho en símbolos jeroglíficos del país del Nilo alusivos a productos compuestos por múltiples partículas pequeñas, como el determinativo incluido en la palabra referida a la sal por ejemplo (Gardiner 1982: 520).

En síntesis, la nueva hipótesis vería en la pieza circular de Nebra sólo una materialización en metal de la cúpula del cielo a la manera como ésta era concebida en la época, con la imagen de tres astros en el centro (Sol, Luna y Venus) y con una alusión lateral a los desplazamientos horizontales de sus ortos y ocasos. Completaría la escena una barca sagrada; y, como fondo sobre el que se desplaza esa nave astral, un mar de puntos, que era la forma de aludir a las innumerables gotas integrantes de las aguas supracelestes (fig. 14).

\section{Primera singladura ibérica}

La identificación como barca astral del motivo representado en la parte inferior del disco de Nebra permite dar un paso más a la hora de interpretar otros temas semejantes localizados ahora en yacimientos prehistóricos del sur de la Península Ibérica. Dichos motivos forman parte del repertorio temático de algunas manifestacio-

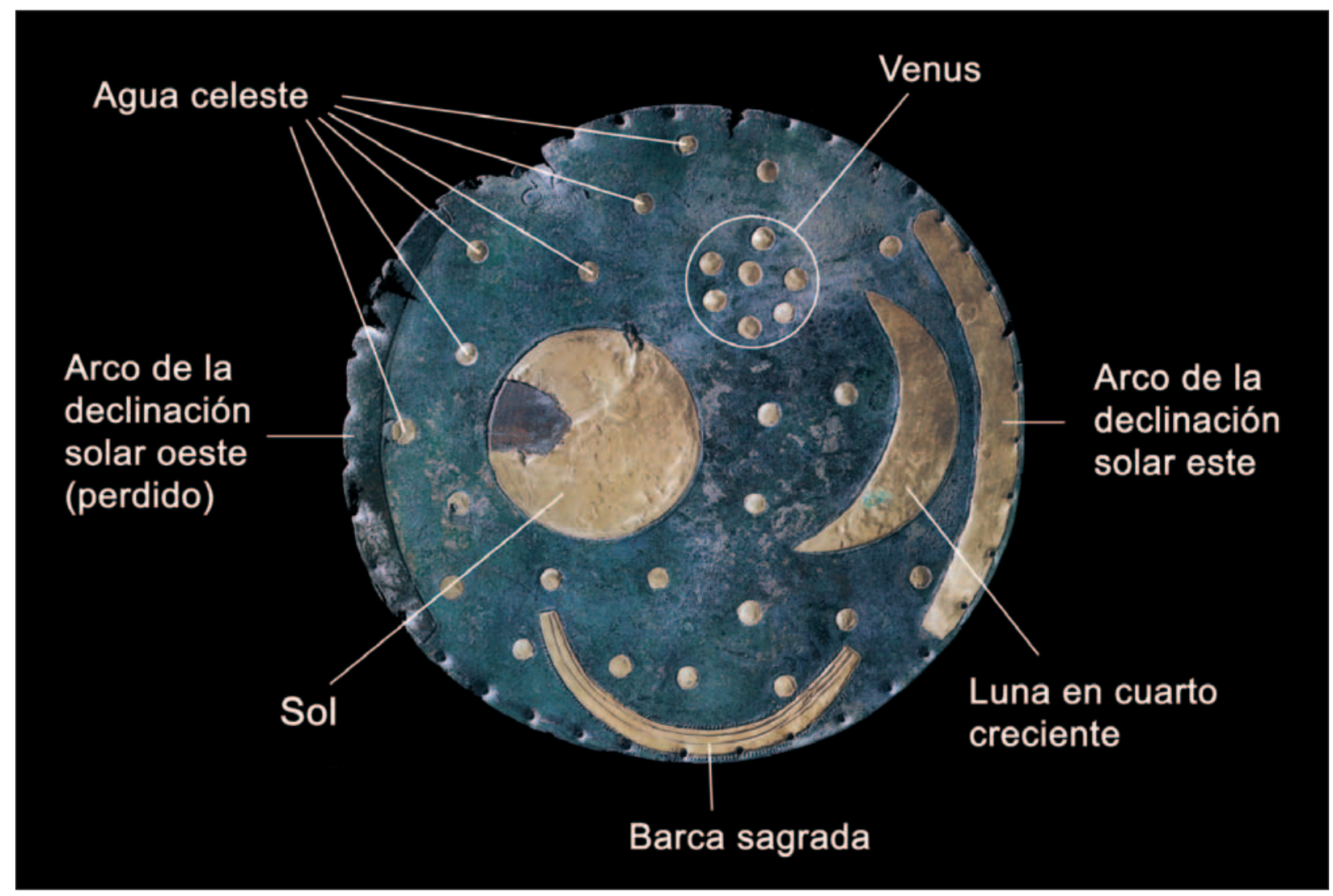

Figura 14. Nueva interpretación del disco de Nebra. 


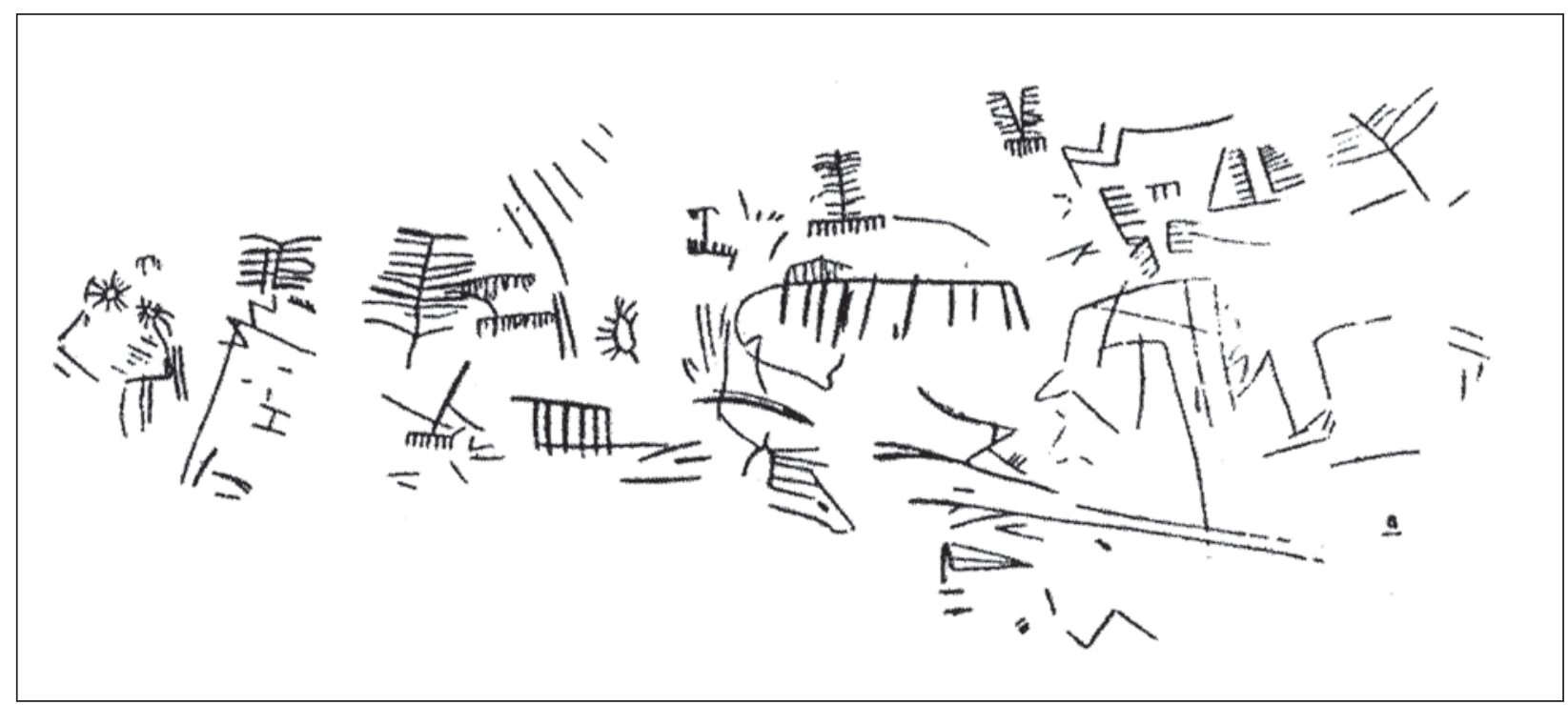

Figura 15. En la pintura postpaleolítica española del arte rupestre esquemático son relativamente frecuentes las asociaciones entre motivos astrales y pectiniformes/ramiformes, una composición alusiva a la barca sagrada que transporta a los dioses por la bóveda celeste. Cueva de la Pileta (Benaoján, Málaga), según Cantalejo y otros (2006)

nes rupestres postpaleolíticas, pero también aparecen en ciertos casos como elementos "decorativos" de la cerámica. En la pintura esquemática, esa particular representación se ha identificado con un animal cuadrúpedo a la carrera, cuando no con un vegetal de tipo arbóreo o similar. Se trata de una abstracción denominada comúnmente "pectiniforme" en el vocabulario especializado (Acosta 1968: 55 y 125-127; 1983: 20; Mas 2001: 170). Dicho elemento se asocia en ciertos paneles rocosos a "esteliformes" o "soliformes" (fig. 15). Su datación, obtenida primero mediante estudios fenéticos, abarca desde los últimos tiempos del Neolítico hasta el Bronce Antiguo, con lo que en parte coincide con la fecha aceptada para el disco de Nebra. Tal cronología ha sido corroborada más tarde mediante análisis radiocarbónicos, que han ofrecido para pectiniformes andaluces cifras de finales de la Edad del Cobre (Sanchidrián y Márquez 2003: 290-291). Pero la unión de pectiniformes y/o ramiformes con estrellas se plasmó en algunos casos, como decoración incisa, en cuencos de la misma época pertenecientes a la denominada vajilla simbólica (Martín y Cámalich 1982: fig. $1, \mathrm{n}^{\circ} 11$ y 21).

La hipótesis trabajada en el presente artículo sostiene que dichos ramiformes y pectiniformes pueden ser en realidad imágenes extremadamente esquemáticas de la barca sagrada cósmica, lo que explicaría su colocación junto a representaciones astrales. En apoyo de la lectura como embarcación de este motivo tan abstracto, independientemente o no de su asociación a esteliformes o heliomorfos, podría acudirse a un testimonio hallado en la década de los 80 del siglo pasado en el asentamiento calcolítico de Los Millares (Arribas y Molina 1987: 136 y fig. 3f; Molina y Cámara 2005: 94). Se trata de un fragmento de cuenco de cerámica a mano que muestra en su cara externa decoración campaniforme y por dentro una embarcación con cabeza de toro en la proa (fig. 16). Entre otras cosas, se trata de un ejemplo hispano de una vieja tradición mediterránea, más

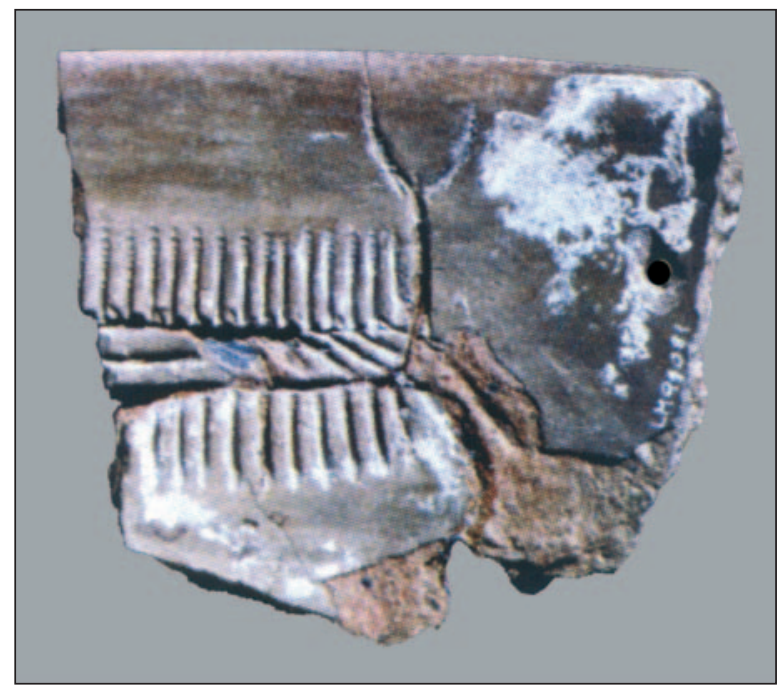

Figura 16. Barco con prótomo de toro sobre cerámica campaniforme. Los Millares. Foto Guía del yacimiento. 
antigua si se quiere en el Próximo Oriente, que plasmaba figuras de barcos en recipientes de barro cocido (Guerrero 2007: 66, fig. 3). De esta tradición se conocen numerosas manifestaciones. Algunas de ellas, especialmente esquemáticas, son casi coetáneas de los casos hispanos estudiados en este trabajo (fig. 17).

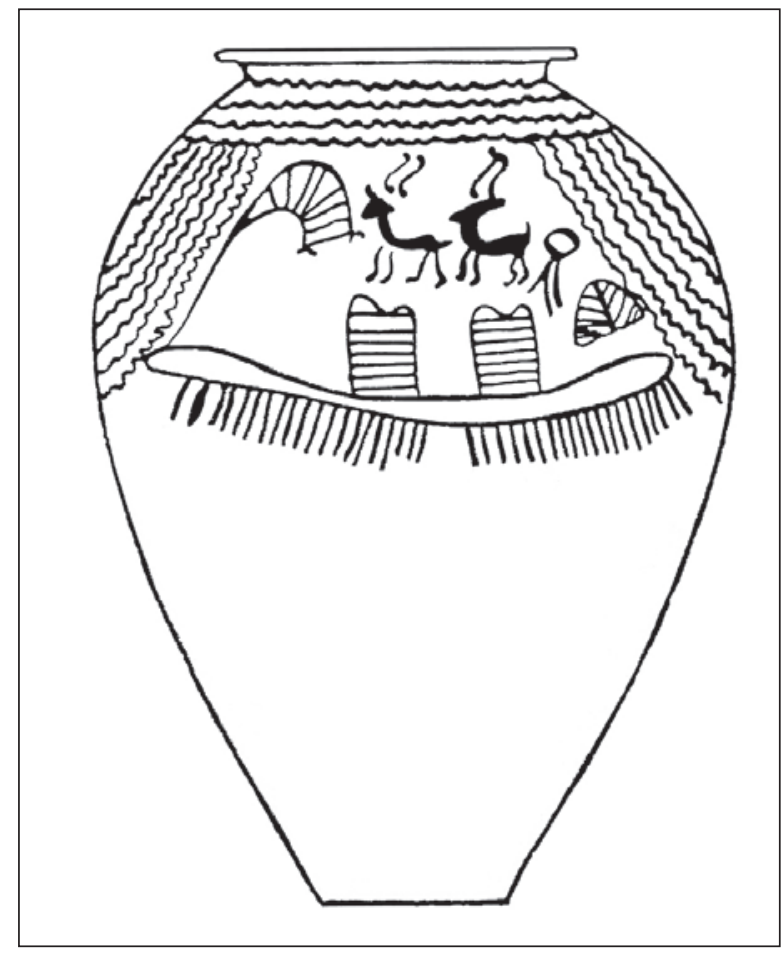

Figura 17. Vasija gerzeense con representación esquemática de una embarcación a remo.

Al tratarse de una vasija de la especie campaniforme, este testimonio almeriense no origina dudas sobre su fecha, con lo que una datación acorde con lo conocido sobre dicho fenómeno en Andalucía lo situaría a fines del Calcolítico, con cronologías absolutas incluidas entre los últimos siglos del tercer milenio a.C. y los comienzos del segundo (Arribas y Molina 1987: 133; Lazarich 2005: 363-365; García Sanjuán 2011: 128-130 y 136-137). Así que de nuevo convendría recordar su proximidad temporal al disco de Nebra; porque, si este último se ha situado en torno al 1600 a.C., el complejo cultural que lo produjo y usó se ha vinculado a grupos sociales arraigados en Sajonia-Anhalt al menos desde el 2000 a.C. (Meller 2004: 74-75).

8 Los términos navales usados en el artículo proceden de Guerrero (1993).
El barco representado en el interior de este cuenco de Los Millares está realizado con simples trazos geométricos, todos rectilíneos si se exceptúan los cuernos del bóvido que remata la proa. Pero esto no obstaculiza en absoluto su reconocimiento como tal embarcación, porque también son muy esquemáticas las siluetas de ciervos incisas en algunas cerámicas cordobesas coetáneas y no por ello se han dejado de identificar como tales ciervos (Lazarich 1999: 552). El de Los Millares responde a uno de los muchos modelos de barcos que en la Prehistoria reciente mediterránea ostentaron una cabeza de animal o algún otro símbolo en la proa, en la popa o en ambas partes (fig. 18). Como no se ha conservado la figura en su totalidad, el presente análisis parte de suponer que el extremo visible es la proa. De hecho, otros fragmentos cerámicos con motivos similares hallados también en el mismo contexto de Los Millares muestran posibles remates de embarcaciones que no llevan este mascarón (¿popas?), tratándose en este caso de extremos situados a la izquierda de la composición (Arribas y Molina 1987: fig. 3e).

$\mathrm{Al}$ casco de la nave se alude con dos incisiones horizontales que convergen en la proa, y que perfilan tal vez las bordas o regalas de babor (línea horizontal superior) y de estribor (línea horizontal inferior $)^{8}$. Un tercer surco, que recorre también en

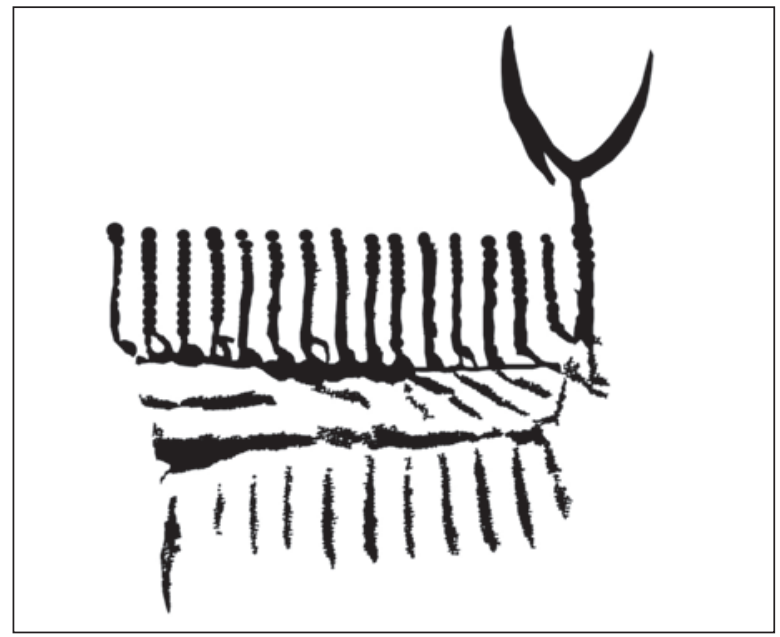

Figura 18: Dibujo del barco representado en el fragmento campaniforme de Los Millares.

Elaboración propia a partir de la foto publicada en la Guía del yacimiento. 
horizontal la parte interior del navío y que se plasma al menos en la mitad izquierda de la representación conservada, puede aludir al nervio central que atraviesa de proa a popa estos modelos de barcos. Dicha pieza, que coincide con el eje de crujía, es un mecanismo indispensable para la navegación marítima. De hecho, se ha sostenido que las maquetas en bronce del mundo nurágico que carecen de esa carena son exvotos o lámparas, y que en ellas se habría sacrificado la imitación fiel de la realidad en aras de su función religiosa (Guerrero 2004: 125). Sin embargo, la parte delantera de la embarcación de Los Millares, esto es, la amura de proa, muestra cuatro o cinco líneas que la atraviesan de banda a banda (fig. 19). Podría pensarse en este caso en los bancos para los remeros, o también en los baos o traviesas para unir de babor a estribor las cuadernas que sostienen la cubierta (Guerrero 1998: 86); pero el hecho de que la quilla se vea en la parte interna sugiere una embarcación sin cubierta, como correspondería a las conocidas para esta época. De ahí que tal vez las líneas transversales situadas junto a la proa sean pañoles, colocados precisamente en los barcos sin cubierta como pequeñas plataformas a proa y a popa bajo las que resguardar enseres y alimentos o desde las que acceder a la roda. Con cubiertas incipientes de este tipo contaban algunos navíos prehistóricos del Mediterráneo occidental (Guerrero 2004: figs. 9 y 12).
Tanto en la parte superior como en la inferior se desarrollan sendas filas de remos que parecen pasar por encima de las bordas correspondientes, y que por tanto no atraviesan los flancos de la nave por gateras. Esto, que es también un rasgo de las embarcaciones mediterráneas de la época, exigiría algún artilugio a modo de chumaceras para sujetar los remos a la parte superior de la borda, elementos que pueden estar representados en unas pequeñas marcas plasmadas sobre la regala en los extremos proximales de las palas de babor. De hecho, unas incisiones en ángulo de $45^{\circ}$ en las bases de los remos ocupan las escalameras o espacios entre los toletes. Es posible también que, al igual que ocurre en las embarcaciones vilanovianas, pero sobre todo en las sardas, se haya querido señalar sobre esta borda de babor una rejilla a modo de escalamote o falca, elemento del que disponen igualmente algunos exvotos nurágicos (Guerrero 2004: 130-131). Todos los remos, en fin, se expresan como líneas paralelas que, en lo conservado, asoman en número de once a estribor (fila inferior) y de quinde a babor (fila superior). De todas formas, parece que esta diferencia numérica entre ambos grupos de remos es un simple accidente producido por la rotura del cuenco. En cualquier caso, quizá uno de los caracteres más destacables es la representación de las palas mediante una sucesión continua de puntillado impreso. Esta técnica es típica de las decoraciones campaniformes, lo que garantiza que el barco se

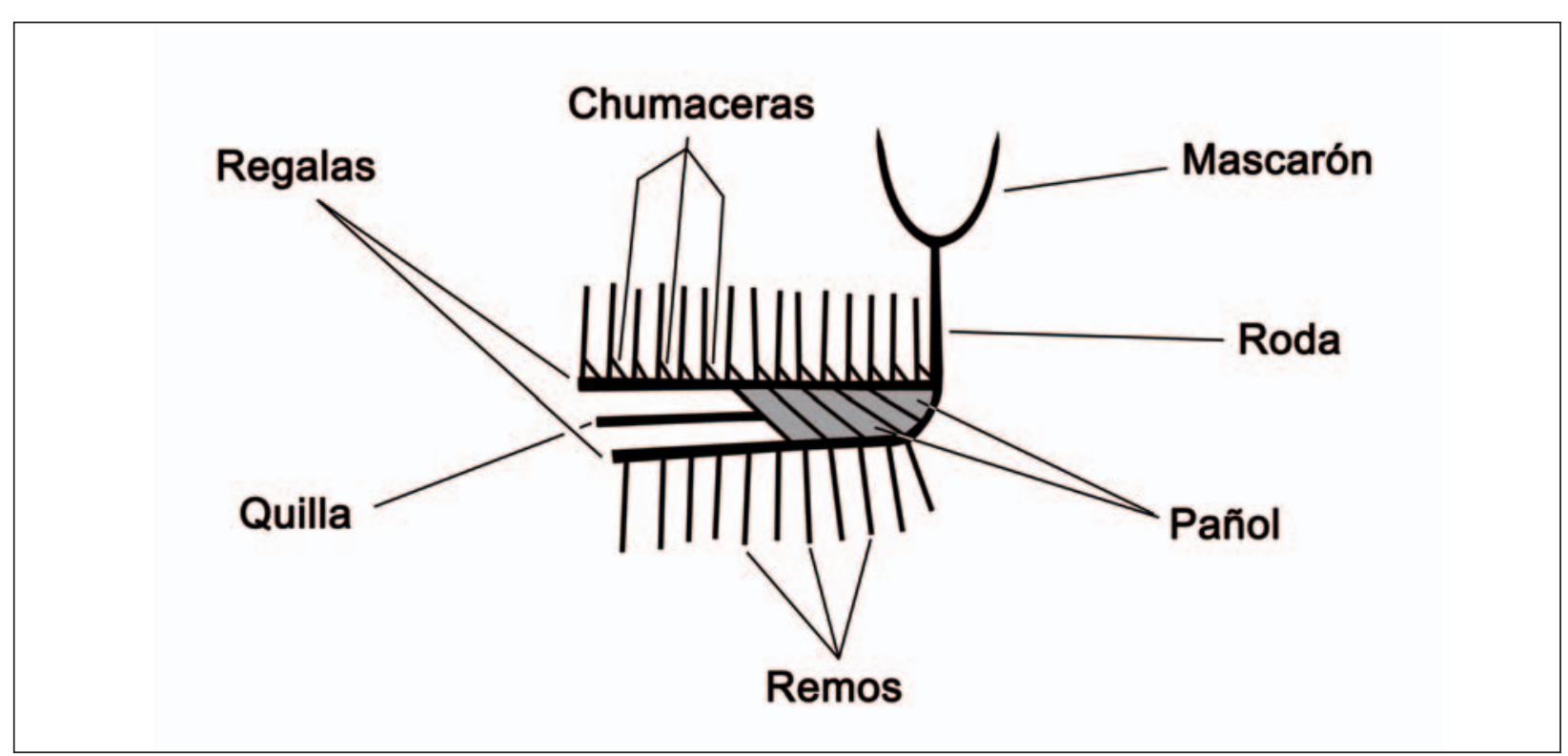

Figura 19. Partes identificadas en el barco del cuenco campaniforme de Los Millares. 
plasmó sobre la cerámica a finales de la Edad del Cobre, y no en una manipulación posterior. Esta cuestión técnica de la alfarería campaniforme se observa relativamente bien en los extremos distales de algunos remos de babor.

El barco de Los Millares plagiaría, pues, las naves de la época que contaban sobre la proa con una alta roda sobre la que se asentaba un mascarón en forma de cabeza de animal, en este caso claramente de bóvido. Toda esta parte está definida por un trazo continuo vertical que remata en dos arcos alusivos a la cornamenta. En el mundo antiguo, y tal vez también en tiempos prehistóricos, dicho mascarón sirvió como emblema de identificación nacional (Luzón 1988: 445-446; Guerrero 2004: 139).

Esta primera singladura por la documentación ibérica ha demostrado que sobre la cerámica hispana de época calcolítica se representaron imágenes de barcos que, a pesar de su extremado esquematismo, contaban con un grado de pulcritud suficiente como para identificarlas como tales naves y poder distinguir con cierto nivel de detalle algunas de sus partes. Aun así, si estos modelos corresponden o no a los barcos reales, los que empleaban las poblaciones de la Edad del Cobre del Mediterráneo occidental en sus desplazamientos marítimos, es un problema que no afecta al núcleo de este artículo. Interesa más aceptar la posible existencia de otra iconografía que, sin tanta pretensión de entrar en minucias, captaba la esencia del mensaje. Igual que la barca sagrada del disco de Nebra no es un calco fiel de ninguna nave genuina, también ciertas representaciones prehistóricas hispanas pudieron limitarse a reflejar una embarcación mediante un único trazo central (casco) del que parten líneas transversales (remos).

\section{Segunda Singladura Ibérica}

Otro documento hispano de interés para construir la presente hipótesis supone un paso más en la tendencia a la simplificación del arte esquemático, sobre todo a la hora de identificar como barcos algunos de sus motivos. En este caso, el tema se expresa si cabe de manera menos realista que en el ya reseñado, donde aún ha sido posible dis- tinguir con relativa precisión el modelo y las partes del barco. El análisis llevado a cabo en el apartado anterior muestra ya, en todo caso, el alto nivel de simplificación que pudieron lograr las representaciones artísticas de la época. Pero la idea de una embarcación pudo esquematizarse aún más, hasta el punto de poderla plasmar como unos escuetos trazos geométricos. En relación con las figuras prehistóricas de navíos, la tendencia a reducirlas se percibe en numerosos casos mediterráneos y atlánticos, por ejemplo en los recogidos para el estudio del comercio marítimo y la piratería por M. Ruiz-Gálvez (2005). Dicho proceso intelectual, técnico y morfológico hacia la sencillez es un rasgo característico del paso del signo al símbolo. Se trata de una transformación que permite al emisor encapsular en una escueta manifestación material un amplio y fecundo pensamiento, que el receptor puede a su vez descodificar y captar en toda su plenitud si participa del mismo universo mental. Con ello, una concisa imagen puede acoger un mensaje profundo que será percibido y comprendido por todas las partes del sistema de comunicación. Antes que perder valor semántico, el arte esquemático de la Prehistoria reciente de la Península Ibérica experimentó una evolución notoria hacia la simplicidad formal sin menoscabo alguno de la información que portaba (Mas y Finlayson 2001: 187; Mas 2005: 166).

Del yacimiento de Los Millares procede un segundo recipiente cerámico "decorado" por su interior con dos representaciones astrales bajo las que se dispusieron otros tantos motivos que podrían describirse indistintamente como ramiformes o como pectiniformes dobles (fig. 20). Este cuenco se halló en la sepultura 15, acompañado en concreto de otras piezas de vajilla simbólica (Leisner 1943: lám. 20, I, 7). Cuando la vasija aún no había entrado en el horno, en su interior se grabaron dos incisiones ovales o subcirculares de contorno muy irregular. De ellas irradian líneas también incisas: dieciséis en el motivo izquierdo y catorce en el derecho. Según la posición en que este cuenco se suele publicar, que podría ser la correcta según veremos, las dos imágenes astrales se situarían en la mitad superior del marco circular señalado por el propio borde del recipiente. Por el contrario, en la parte 


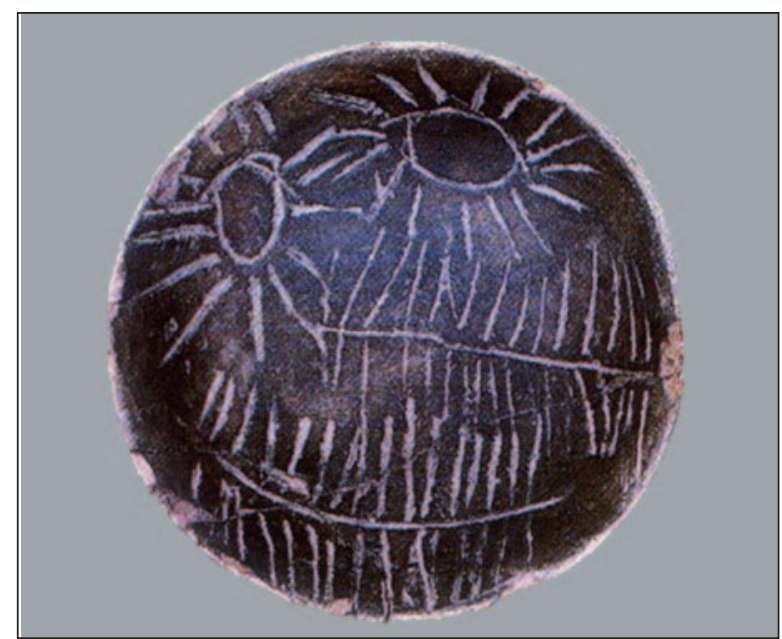

Figura 20. Cuenco de cerámica con decoración simbólica procedente de la tumba 15 de Los Millares. La composición puede interpretarse como dos astros con sus correspondientes barcas sagradas.

inferior se habrían emplazado dos incisiones de tendencia horizontal, más curva la de abajo que la de arriba, de las que salen, tanto hacia un flanco como hacia el opuesto, trazos perpendiculares también incisos (Martín y Cámalich 1982: 292).

Lógicamente, los elementos superiores de la escena han sido siempre identificados como cuerpos celestes, se les denomine esteliformes, heliomorfos o simplemente motivos astrales. Pero apenas se ha dicho nada de los inferiores. Sólo en una publicación anterior a ésta trabajé con otros colegas la idea de que fueran barcos muy esquemáticos (Escacena y otros 2009), interpretación asumida ya en algunos trabajos posteriores que han valorado la hipótesis (Guerrero 2010: 32 y 37). En cualquier caso, los términos al uso para designar tales motivos -«ramiformes» en este caso- son sólo descriptores formales del signo; no aluden al contenido semántico del mensaje que puedan transmitir. En consecuencia, y visto cómo se representó el barco cósmico de Nebra, nada impide reconocer aquí unos elementos y una composición semejantes a las de aquel disco metálico. Este otro cuenco de Los Millares supondría entonces la visión de la bóveda celeste que poseyeron las sociedades calcolíticas del mediodía ibérico: astros-dioses que se desplazan por el firmamento sobre embarcaciones sagradas.

Las semejanzas y diferencias con el disco de Nebra explicarían igualmente algunos otros detalles de este pequeño cuenco hispano. Por lo pron- to, cabría sospechar que, si sólo se alude a dos cuerpos celestes, éstos sean el Sol y la Luna; primero porque son los astros más evidentes para quien mira al cielo desde la Tierra sin aparatos ópticos de precisión, y segundo porque es posible que también en la Península Ibérica la figura de Venus conociera una representación similar a la nube de puntos del disco de Nebra, cuestión que veremos enseguida. De ser así, y si el disco celeste de Nebra fuera producto de una imagen más o menos estereotipada de la bóveda del firmamento, en este segundo cuenco de Los Millares el cuerpo radiado de la izquierda representaría al Sol y el de la derecha a la Luna. En apoyo de esta identificación concreta podría acudirse al número de rayos de cada objeto, mayor en el primero que en el segundo como corresponde a la más intensa luminosidad solar. Ello supone asumir que la diferencia entre ambas cantidades de ráfagas radiales no sería gratuita. Como en Nebra, el Sol ocuparía la izquierda de la composición y la Luna la derecha. Sin embargo, existen otras posibilidades de interpretación que pueden ser más fructíferas.

Una de ellas es que se trate más bien de una alusión al Sol y a Venus. La razón fundamental de esta otra lectura es que la Luna, a diferencia de cualquier otro astro visible con nitidez a ojo desnudo, muestra claramente momentos distintos de luminosidad y de forma según el día del ciclo en que se encuentre. Como los planetas carecen igualmente de luz propia, estos mismos eventos se producen también en ellos; pero en este caso su mayor distancia impedía percibir que se trataba de brillo reflejado. De ahí que las culturas antiguas representaran a la Luna casi siempre en sus situaciones de mayor personalidad, es decir, en sus fases creciente o menguante, o incluso como novilunio. Estas siluetas la hacían inconfundible, como de nuevo demuestran los kudurru mesopotámicos o el propio disco de Nebra. Además, es muy probable que la humanidad supiera desde tiempos muy remotos que la Luna no irradia luz propia. Un simple eclipse de Sol, fenómeno del que existen referencias en el mundo antiguo, era suficiente para percibir que nuestro satélite carece de la capacidad de emitir luz generada por sí mismo. Por esto, los cuerpos celestes representados con rayos pueden referirse más bien a estrellas y cometas, al Sol y a los planetas del sistema 
solar. Y pueden incluirse en la lista a cometas y planetas porque, a pesar de que tampoco generan luz propia, su distancia de la Tierra y/o su pequeñez impedían a los observadores prehistóricos descubrir ese rasgo concreto, simplemente porque carecían de los medios técnicos para ello. A diferencia de la Luna, tan cercana a nosotros, esa misma lejanía los hacía imperceptibles en los momentos de tránsito por delante del disco solar. Es más, ocasionaba que su luz reflejada centelleara si su observación se producía cuando se encontraban cerca de la línea del horizonte, debido en estos casos al mayor espesor de la capa atmosférica que debía atravesar. Todo ello pudo ocasionar la creencia en tiempos prehistóricos de que los planetas producían luz original. De ser así, este cuenco de la sepultura 15 de Los Millares podría representar a la pareja divina Sol-Venus, que no sería más que la correspondencia astral de los dos dioses (uno masculino y otro femenino) personificados en los idolillos antropomorfos del Calcolítico de la Península Ibérica.

Una tercera posibilidad es que se trate de dos facetas distintas de un mismo astro. Aunque esta hipótesis parece algo extraña a nuestra mentalidad científica moderna, no es descabellada para el mundo prehistórico y antiguo. Así, podríamos estar ante una imagen dual del planeta Venus en tanto que Lucero de la mañana y de la tarde. Como Venus sólo es perceptible durante el alba y al atardecer, porque la propia luz solar lo apaga a pleno día, durante un tiempo pudo existir la creencia de que eran dos objetos distintos. Así se ha interpretado por ejemplo la dualidad representada por las diosas Anat (Lucero matutino) y Astarté (Lucero vespertino), divinidades de la guerra y del amor respectivamente en el mundo cananeo del segundo milenio a.C. (Belmonte 1999: 115116). La desaparición de Anat del posterior panteón fenicio del milenio siguiente sugeriría, por consiguiente, que ambas manifestaciones de Venus se reconocieron ya como posiciones distintas de un solo cuerpo celeste. Esas epifanías de una misma divinidad-astro eran asumidas como entidades parcialmente diferentes en otras culturas de la época. Por eso, también puede pensarse en dos manifestaciones del Sol, como Horus (el Sol niño o matutino) y Osiris (el Sol poniente) eran en Egipto en realidad dos facies de Ra. Esta cuestión ha suscitado una honda polémica entre los especialistas en religiones antiguas, que en algunos casos no saben si considerarlas realmente credos politeístas o si se trata más bien de un monoteísmo que contiene diferentes advocaciones de un mismo y único numen (Hornung 1999).

Ninguna de estas tres opciones señaladas cuenta en principio con datos suficientes como para vencer claramente a las demás, aunque algunas candidatas muestran más fuerza que otras. La presencia de dos barcos en la parte inferior del cuenco, uno para cada astro, parece primar la idea de dos cuerpos celestes distintos, en cuyo caso habría que descartar la identificación del Sol en dos de sus hierofanías horarias, al modo de las personificadas por Horus y Osiris en Egipto. Tampoco parece probable la presencia de la Luna por las razones expuestas más arriba. Por ello, de las posibilidades barajadas sólo son más plausibles las de la pareja Sol-Venus y la de Venus matutino-Venus vespertino. La segunda explicación supondría aceptar que las culturas calcolíticas hispanas también creyeron, como los cananeos del segundo milenio a.C., que el Lucero del alba era un astro distinto del Lucero de la tarde. La primera en cambio hablaría de que en el Mediterráneo occidental de la Edad del Cobre se conocía ya la pareja divina y astral Sol-Venus. Si en esta argumentación puede parecer más factible aceptar el matrimonio sagrado Sol-Venus se debe sobre todo a la existencia de otro documento singular que estudiaré más adelante. Me refiero al vaso cordobés de la Cueva de la Murcielaguina, cuya posible cronología neolítica haría de esta asociación Sol-Venus una creencia muy antigua en la zona.

En el cuenco de la sepultura 15 de Los Millares las figuras de las correspondientes barcas sagradas son también, como en Nebra, elementos alegóricos más que imitaciones de naves reales. En las dos embarcaciones se plasma un número similar de remos. Pero desconozco si el hecho de que sean en torno a dieciséis por banda en cada una, casi el mismo número con que cuenta el barco de Los Millares examinado en el apartado anterior, es algo inspirado o no en una posible realidad naval calcolítica. A este respecto, V. Guerrero ha discrepado de la interpretación que 
en 2009 llevamos a cabo de la nave del cuenco campaniforme (Escacena y otros 2009: 258-262); $\mathrm{y}$ ha propuesto como alternativa unos modelos de barcos calcolíticos occidentales mucho más simples, distintos en cualquier caso de los que describiría aquella "decoración" cerámica (Guerrero 2010: 32 ss.). Pero, como ha reconocido que en ella se materializa efectivamente una nave, para desplazamientos marítimos en concreto, tal polémica no afecta al tema central del presente artículo, donde las representaciones de barcos constituyen casi siempre imágenes simbólicas más que fotos específicas de supuestas realidades.

A pesar de que estas alusiones metafóricas sacrifican la imitación fiel de los barcos de la época, el análisis de la embarcación del cuenco campaniforme de Los Millares ha revelado numerosos pormenores de la construcción naval prehistórica. Esos detalles disponen de referencias parecidas en los exvotos metálicos sardos; pero esa cerámica española es claramente anterior a los testimonios nurágicos, que no pueden remontarse más allá del 1300 a.C. (Guerrero 2004: 119-128). En los cuencos millarenses estudiados hasta aquí, su mayor interés reside en el grado de esquematización alcanzado por la imagen. Este rasgo permite proponer que la mínima expresión donde reconocer un barco pudo limitarse en esa época a unos cuantos trazos paralelos para los remos y a una línea perpendicular a éstos para el casco. Como demuestra el disco de Nebra, el propio cuerpo del navío puede llegar a convertirse en un arco elemental. Para comprender esta acusada tendencia al esquematismo, reductor del signo sin un paralelo proceso de pérdida del contenido semántico, es paradigmático el conjunto de grafitos del templo de Tarxien, en la isla de Malta. Esas incisiones muestran barcos más realistas junto a otros mucho más abstractos (Guerrero 1993: fig. 11). Otros ejemplos del mismo fenómeno pueden recabarse en áreas más alejadas del Mediterráneo, por ejemplo en el mundo egipcio prefaraónico, donde una embarcación puede llegar a pintarse con un simple conjunto de trazos geométricos como ya hemos visto. En el grabado maltés se representaron navíos en distinto grado de esquematización. Uno de ellos, el ubicado en la parte inferior derecha, podría definirse como un claro pectiniforme si usáramos la nomenclatura empleada en los estudios sobre arte parietal postpaleolítico hispano (fig. 21). Unido a la elocuente figura del fragmento campaniforme de Los Millares y a la más básica del disco de Nebra, este caso permite considerar representaciones de barcos algunos pectiniformes y ramiformes de las cerámicas simbólicas hispanas, ahora especialmente los del cuenco de la sepultura 15 de Los Millares. De la misma forma, podrían aludir también a barcas sagradas los ramiformes y pectiniformes asociados a representaciones astrales en la pintura esquemática del mediodía ibérico, y que ya hemos analizado más extensamente en un trabajo anterior (Escacena y otros 2009: 270-272): Prado del Azogue, en Aldeaquemada (Jaén), con posibles naves en forma de artesa como la del petroglifo gallego de Borna (cf. Alonso Romero 1974: figs. 2 ss.); Vacas del Retamoso-Los Órganos de Despeñaperros, también en la provincia de Jaén (López Payer 1988: 92-97); y el Letrero de los Mártires, en la localidad granadina de Huéscar.

Si el cuenco de Los Millares reseñado en esta segunda singladura ibérica está bien publicado en la posición en que tradicionalmente se hace, la misma adoptada aquí, es sólo porque los ramifor-

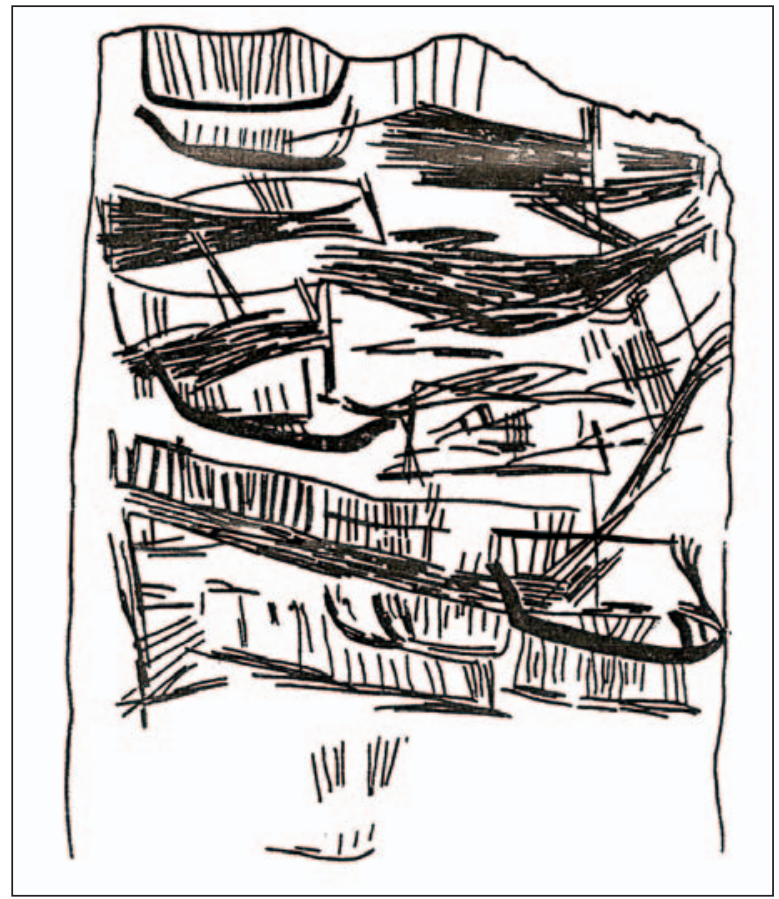

Figura 21. Grafitos de Tarxien (Malta), según Guerrero (1993). La coexistencia de representaciones más realistas con otras mucho más esquemáticas permite identificar las segundas a partir de las primeras: embarcaciones con sus cuerpos de remos. 
mes inferiores son representaciones de la barca astral. Esto elimina la posibilidad de leerlo correctamente desde otros ángulos. Girado $180^{\circ}$ podría pensarse en dos ojos con sus cejas correspondientes. Tal perspectiva estaría inspirada en los idolillos coetáneos, aunque habría que reconocer el trabajo especialmente descuidado del alfarero. Igualmente, habría que admitir la singularidad de unas cejas con pelos que se bifurcan desde una línea central, cosa desconocida en los idolillos. Asumir entonces que estamos ante dos astros con sus correspondientes embarcaciones sagradas permite dar un paso más a la hora de percibir cómo las poblaciones hispanas de la época imaginaron el cosmos y su funcionamiento.

\section{Tercera Singladura Ibérica}

La representación de Venus como un conglomerado de puntos puede disponer de un testimonio muy arcaico en la propia Península Ibérica. De la Cueva de la Murcielaguina, en la Subbética cordobesa, procede un vaso de cerámica de cuerpo ovoide atribuido a finales del Neolítico por su tipología y técnica decorativa. Pero, al ser un hallazgo sin contexto estratigráfico conocido, su cronología no está asegurada. En cualquier caso, de ser algo posterior estaríamos en realidad ante un caso especialmente infrecuente en la vajilla calcolítica andaluza. De ahí que pueda validarse en principio la fecha neolítica adelantada por B. Gavilán (1989).

El recipiente presenta por el exterior dos líneas verticales que cuelgan del borde y de las que parten en perpendicular otras muchas incisiones, dobles en un caso y sencillas en otro (fig. 22). Podría tratarse aquí también de ramiformes o pectiniformes. Su asociación a un gran heliomorfo central inciso y a series de puntos impresos sugiere que estamos ante el mismo tema ya tratado en el cuenco de la tumba 15 de Los Millares. Sin embargo, las palas estarían aquí mucho más desarrolladas con relación al casco de la embarcación, al modo como se representaron en la pintura postpaleolítica de Puerto del Viento, en Ronda

\footnotetext{
${ }^{9}$ M. Almagro-Gorbea (1988: fig. 3C) cita este sitio como "Km. 12 de la carretera de Ronda a El Burgo".
}

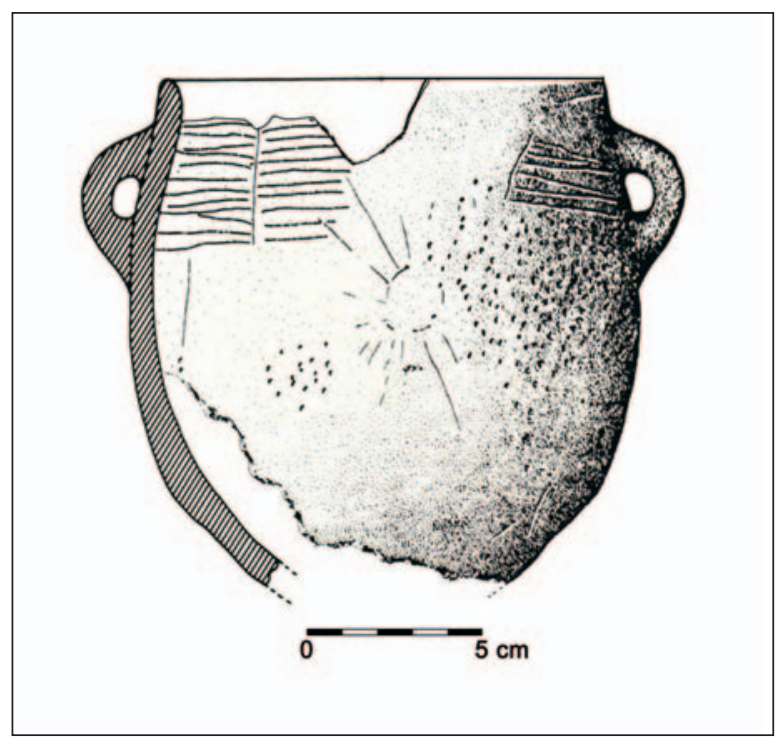

Figura 22. Vaso neolítico de la Cueva de la Murcielaguina (Priego, Córdoba), según Gavilán (1989). $\mathrm{Su}$ adscripción cronológica se ha llevado a capo mediante el análisis tipológico de la forma y de la decoración, pues carece de contexto estratigráfico conocido.

(Cantalejo y otros 2006: 114)9. En este panel rupestre algunos remos son casi tan largos como la barcaza que impulsan (fig. 23). Pero en este vaso pueden señalarse otros elementos que presentan mayor interés. Para ello convendría no olvidar que, al ser un recipiente cerrado, los motivos plasmados en él sólo eran visibles si se desenvolvían en la cara externa. Por otra parte, no toda vasija prehistórica debe tomarse necesaria y exclusivamente por contenedor; puede ser también un soporte plástico para mensajes simbólicos. Ello aconseja contar al menos con la posibilidad de dos posiciones de lectura, la que supondríamos normal y la invertida.

Aparte del ramiforme y del pectiniforme, que podrían ser interpretados de nuevo como barcas sagradas, el centro de la composición está ocupado por una imagen incisa del Sol y por dos lotes de puntos impresos, uno pequeño y denso y otro más indefinido y con impresiones distribuidas de forma más aleatoria. Ante este panorama "decorativo", y contando con los paralelos iconográficos hasta ahora barajados, sería posible argumentar que la presencia de dos embarcaciones estaría 


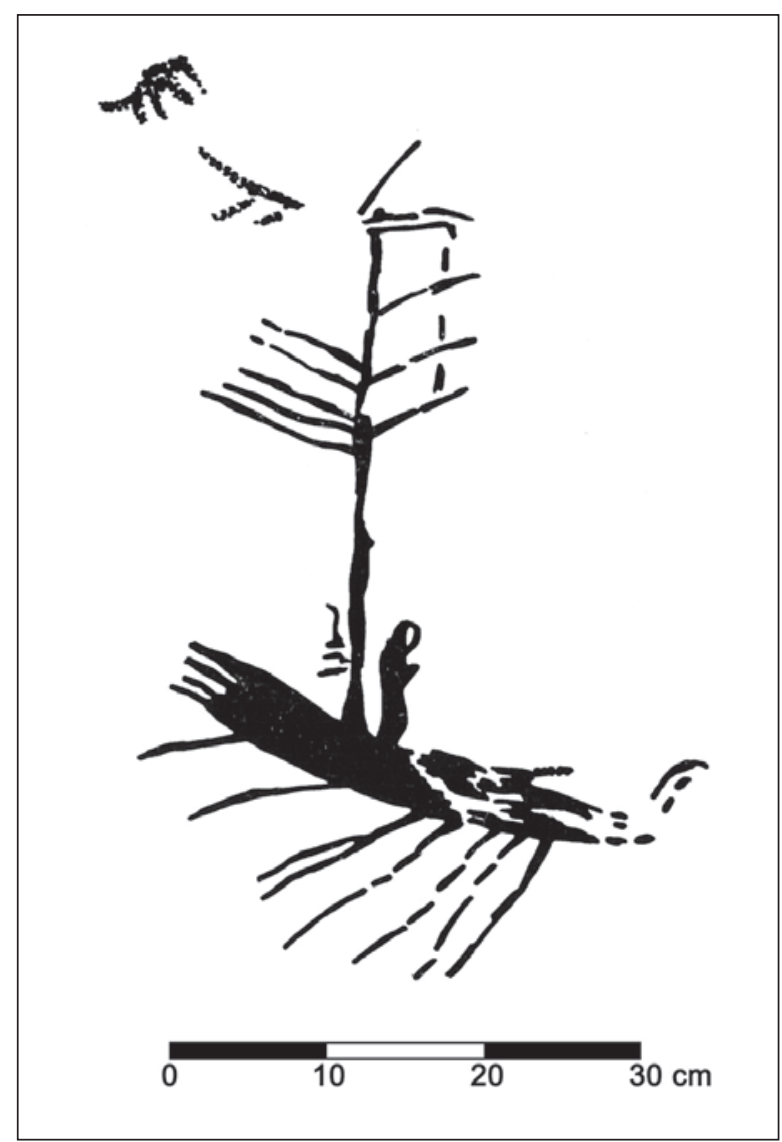

Figura 23. Pintura rupestre de Puerto del Viento (Ronda, Málaga). Detalle de la embarcación. A partir de Dams (1983).

motivada por la inclusión en el conjunto de dos cuerpos celestes. Así que, si contamos ya claramente con el Sol, materializado en el heliomorfo central, el otro podría estar concretado en la nubecilla de puntos tupida. Esta imagen no correspondería aquí tampoco a una constelación, sino al planeta Venus, que se habría expresado con un diseño similar al que tiempo después se usaría, de forma más simple y estandarizada, en el disco de Nebra. De ser así, debe rechazarse la primera interpretación que hicimos de este motivo en el vaso cordobés llevados por la explicación clásica del mismo en la pieza alemana (Escacena y otros 2009: 264). Todo ello deja de nuevo vía libre para ver en la agregación de puntos difusos colocada al otro lado del soliforme una masa de agua sideral representada por gotas distribuidas más o menos al azar por la superficie (fig. 24). Se trata de la misma idea transmitida por las imágenes más explícitas de la bóveda celeste procedentes del antiguo Egipto. De esta forma, el vaso de la Cueva de la Murcielaguina mostraría un mensaje

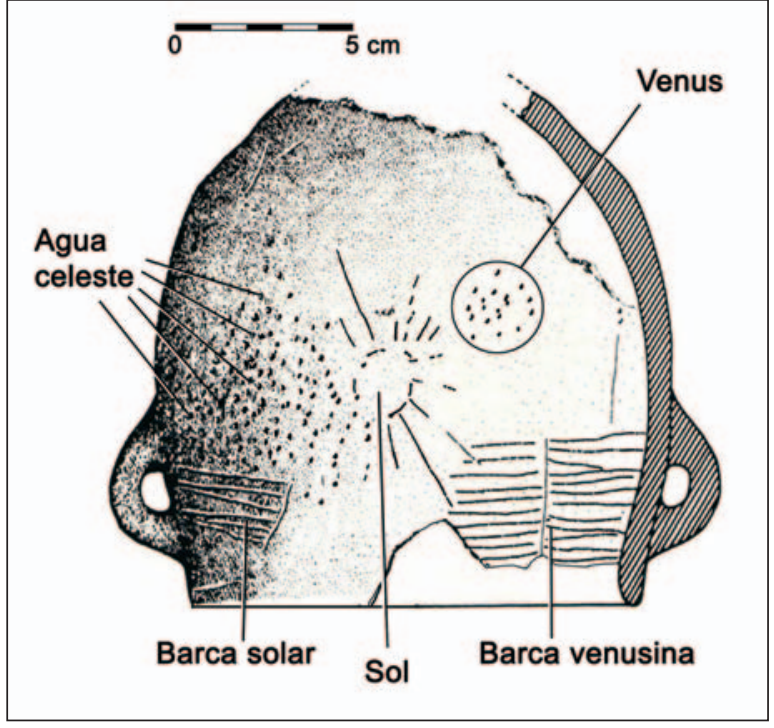

Figura 24. Vaso de la Cueva de la Murcielaguina. Hipótesis interpretativa.

en parte similar al del disco de Nebra, aunque en este caso sobre un testimonio hispano más arcaico. Sólo la Luna estaría ausente, por lo menos de la parte del recipiente que ha llegado hasta nosotros. Dicha semejanza aumenta al observar el vaso en posición invertida, ya que Venus aparece así junto al Sol en idéntica disposición que en Nebra, de hecho donde este planeta se ve normalmente tanto al atardecer como al amanecer: por encima del disco solar. De ser acertada esta lectura, se trataría de la representación occidental más antigua conocida de la bóveda celeste, y en concreto de la pareja divina Sol-Venus. El mensaje que esta composición transmite resulta extremadamente parecido al mostrado por uno de los paneles de pintura rupestre esquemática de Laja Prieta, en la localidad malagueña de Álora (Maura 2011: 201-203). Aquí se pintaron sólo esteliformes y heliomorfos sobre densos campos de puntuaciones. Dichos paneles muestran estrellas fijas del fondo del firmamento o el Sol y algunos planetas, dispuestos todos ellos sobre las gotas de agua que conforman el piélago cósmico (fig. 25). La vasija cordobesa puede verse entonces como una base cerámica para el mensaje que porta, y no sólo como un mero envase. Esto permitiría aceptar que, llegado el caso, su posición adecuada de lectura era realmente boca abajo. Contemplada así, los barcos quedarían en la parte inferior, como en las demás escenas ya comentadas, el sitio correcto para que sobre ellos se des- 


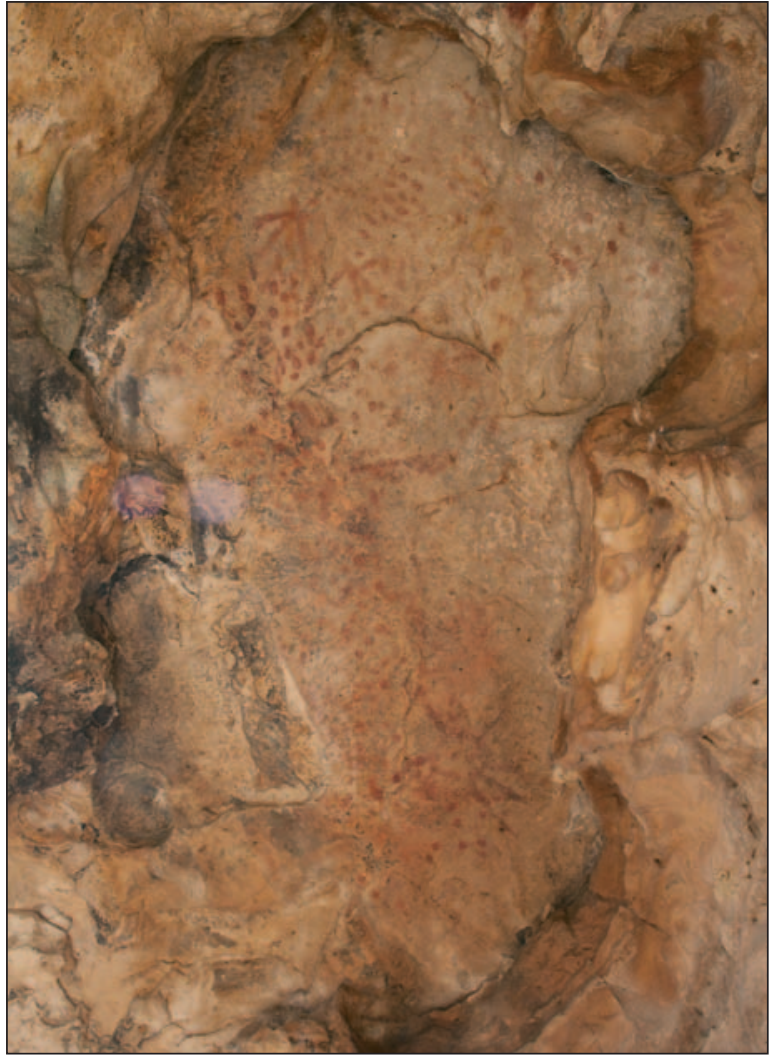

Figura 25. Laja Prieta (Álora, Málaga); abrigo 2. Sobre un campo de puntos (agua cósmica) se representan el

Sol (abajo) y otros tres cuerpos celestes (arriba). Fotografía J. Pérez González publicada en Maura (2011).

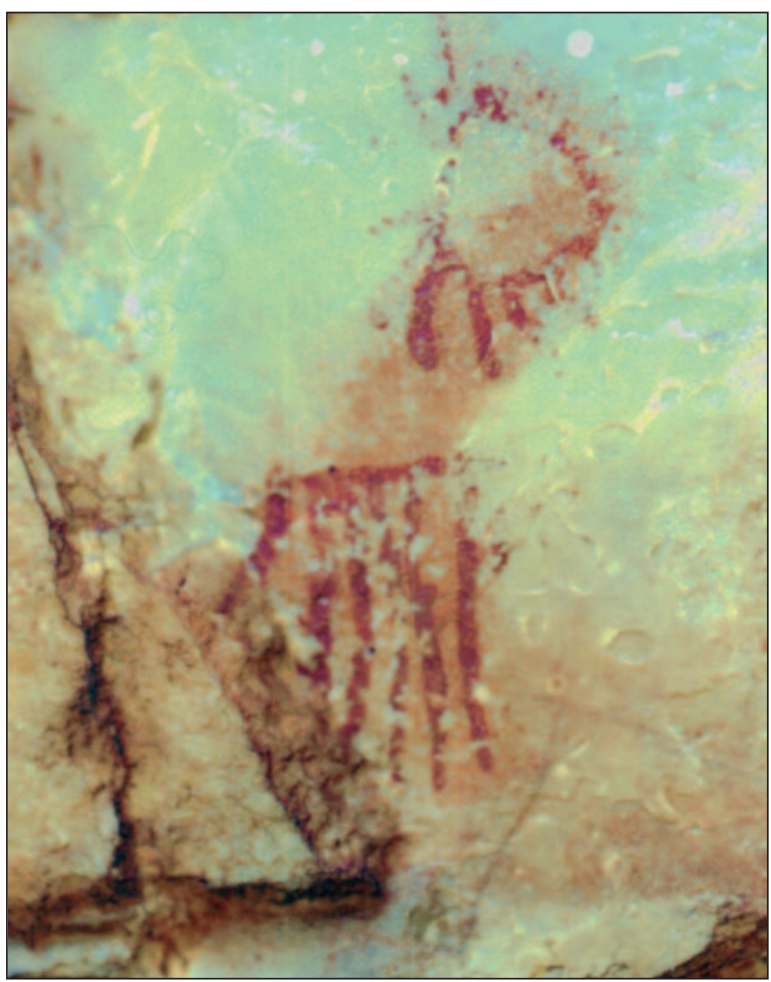

Figura 26. Abrigo del Pectisol. Foto H. Collado. Composición parecida a la del cuenco de la tumba 15 de Los Millares. Aquí puede interpretarse como el Sol sobre su barca cósmica. plazaran por la bóveda del firmamento los astros allí presentes. Se trataría, además, de una colocación recomendada por algunas pinturas rupestres en las que los esteliformes aparecen sobre los pectiniformes, y no al contrario. Un ejemplo claro de tal disposición corresponde al Abrigo del Pectisol (Collado y García Arranz 2005: 35; Collado 2009: 96-97). Este panel extremeño de arte esquemático se une así a la relación citada en el apartado anterior. En él, el Sol navega sobre una nave representada sólo con un trazo horizontal para el casco y seis largas líneas verticales para los remos (fig. 26). Igualmente, el ramiforme pintado sobre un campo de puntos de El Mirador, en la localidad cacereña de Serradilla (Collado y García Arranz 2005: 38), podría explicarse con los mismos argumentos: una barca astral cerniéndose sobre la superficie de las aguas supracelestes, que se representan aquí mediante circulillos casi tan perfectos como los del disco de Nebra (fig. 27).

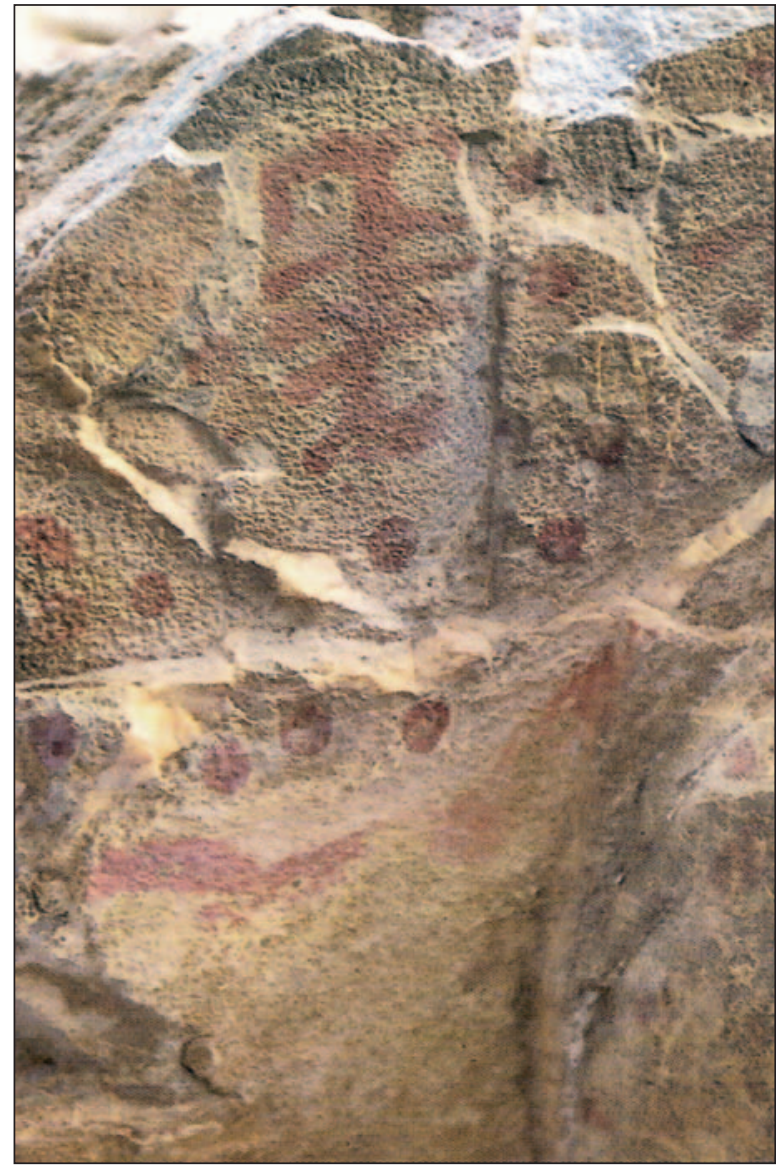

Figura 27. Pintura rupestre de El Mirador. Barca astral (ramiforme vertical superior) navegando por las aguas celestes, representadas aquí con pequeños círculos como los del disco de Nebra. Fotografía de Collado y García Arranz (2005). 


\section{Llegada A PUERTO}

Muchos yacimientos de la Península Ibérica fechables entre el Neolítico y la Edad del Bronce cuentan con datos interesantes sobre los conocimientos que las sociedades prehistóricas de esa época tuvieron sobre el cosmos. Para demostrarlo, basta con traer aquí las regularidades observadas en la orientación de las tumbas, fenómeno del que ya existe una prolija literatura. Renunciaré a tratar dicho aspecto por no ser el tema de este trabajo. Si este dato debe recordarse ahora es sólo porque gran parte de los documentos ahora analizados proceden precisamente de sepulturas y porque muchas alineaciones megalíticas de Europa occidental sugieren estrechos vínculos con las posiciones solares o con otros eventos astronómicos (González García 2009: 185-186; Hoskin 2009: 166-171). Ello sugiere una especial relación entre el mundo de ultratumba y el cielo, una vinculación que, aparte de ser el soporte de numerosas ideologías y prácticas sociales antiguas (Iwaniszewski 2009: 24), constituirá el precedente prehistórico de diversos credos religiosos actuales. De todas formas, y por tratarse de un caso tenido en cuenta en mucha menor medida, puede recordarse que esta preocupación por una determinada alineación astronómica no sólo se constata en las construcciones funerarias, sino que se ha observado recientemente también en asentamientos con fosos (Valera 2008; Valera y Becker 2011).

La plasmación sobre vasos cerámicos de esa cosmovisión y de esos saberes no se limitó a los elementos hasta ahora reseñados. Son numerosos los testimonios calcolíticos que pueden señalarse en este conjunto de datos. Unos constituyen representaciones elementales de esteliformes, pero en otros pueden observarse cosas más complejas. Así, se ha querido ver un cometa en un recipiente del poblado portugués de Outeiro de Sâo Mamede (Cardoso y André 2005: fig. 1), o podemos imaginar incluso una representación del halo solar en otro cuenco muy plano de Almizaraque perteneciente a la colección Siret (fig. 28). En este último caso estaríamos ante la captación de un fenómeno similar al que se ha querido reconocer en un friso de la tumba egipcia de Meryra, sacerdote de Atón (Congdom 2000).

Pero uno de los vasos hispanos de mayor complejidad, y de interpretación más dificultosa por no haberse conservado entero, tal vez sea el recuperado en la sepultura XXI de Los Millares (Almagro y Arribas 1963: lám. CXIX). Si se toman en consideración de nuevo las elocuentes imágenes egipcias sobre el tema, quizá lo más

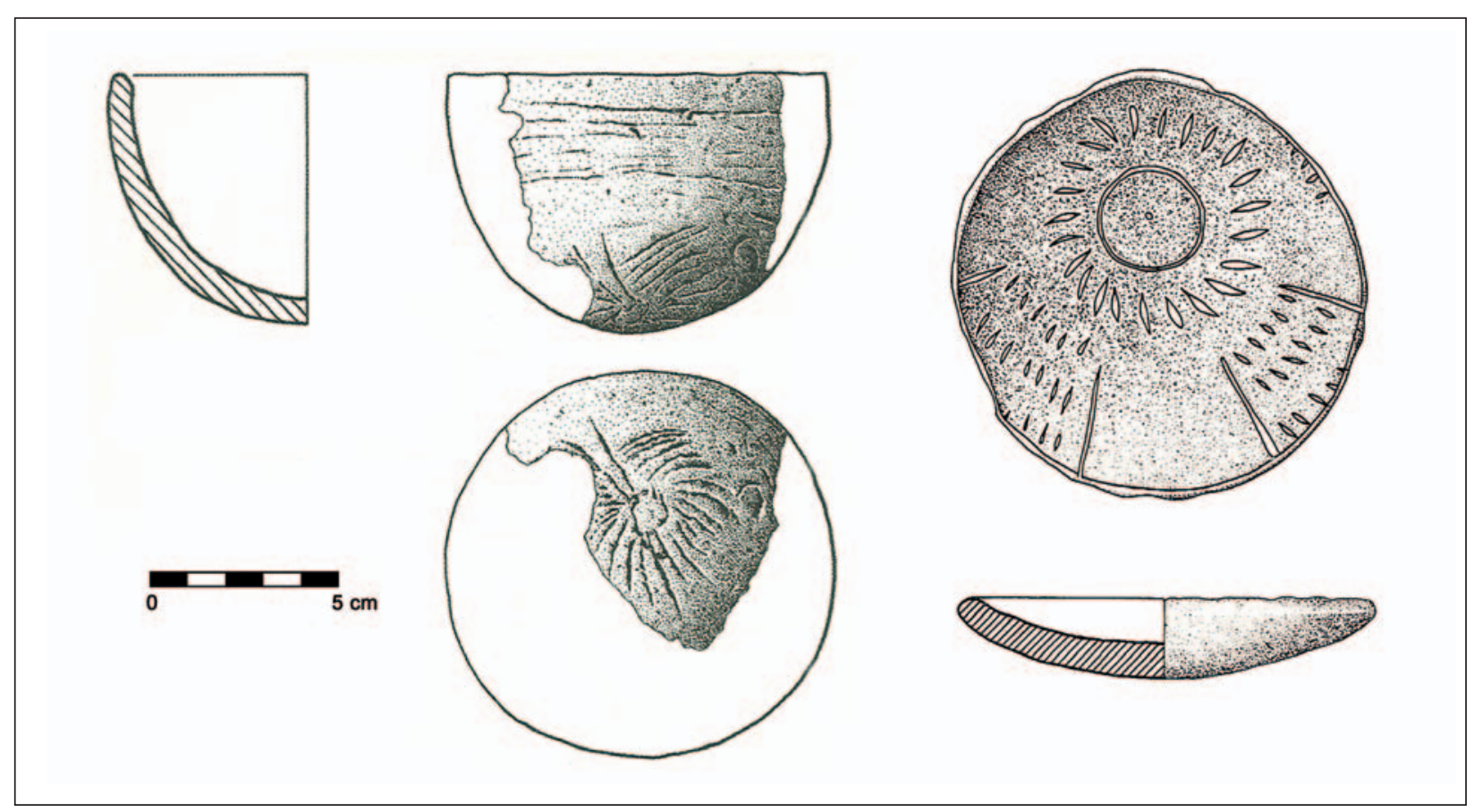

Figura 28. A la izquierda, cuenco calcolítico con representación de un cometa. Procede del yacimiento portugués de Outeiro de Sâo Mamede. Dibujo de Cardoso y André (2005). A la derecha, heliomorfo con halo solar sobre un cuenco procedente de Almizaraque (Almería). Dibujo de Martín y Cámalich (1992). 
prudente sea, de momento, sólo proponer la identificación de algunos elementos que pueden ser relativamente seguros y dejar la interpretación global para cuando se haya avanzado más en el conocimiento de estos aspectos (fig. 29). Estarían presentes aquí las aguas situadas por encima de la bóveda celeste (área de puntos junto al borde del recipiente), las aguas de debajo del firmamento o terrestres (líneas horizontales en zigzag), el panteón de dioses-astros (banda inferior) y, presidiendo la escena, una divinidad-astro principal (Sol) sobre una posible barca sagrada. De esta última sólo se habría conservado uno de sus extremos (sector perdido).
Tal vez el testimonio más completo de cuantos se conocen corresponda a un cuenco hemisférico rescatado también en Los Millares, en concreto en la sepultura 17 (Martín y Cámalich 1982: fig. 1, $\mathrm{n}^{\mathrm{o}} 21$ ), en un contexto de Calcolítico final por acompañar a cerámica campaniforme (Almagro y Arribas 1963: lám. XVI). Este caso representa hasta la fecha la narración más detallada de las ideas acerca del cosmos que poseyeron las sociedades calcolíticas occidentales, al menos aquellas que poblaban el mediodía ibérico. Como se verá, su interpretación exige una posición de lectura ligeramente distinta de la que suele aceptarse en las publicaciones (fig. 30). Vayamos por partes.

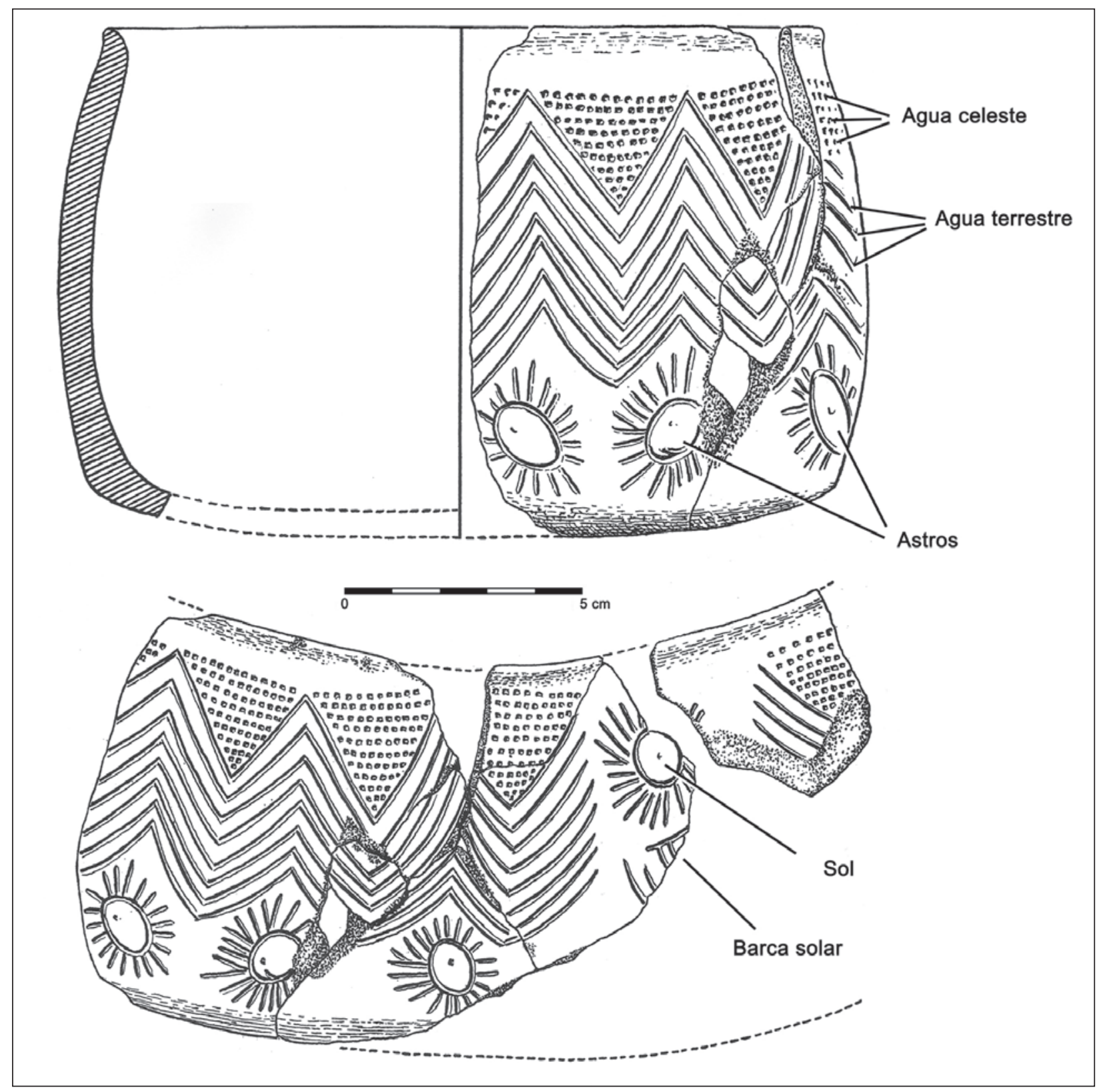

Figura 29. Los Millares. Vaso de la sepultura XXI. Interpretación hipotética de su decoración. 

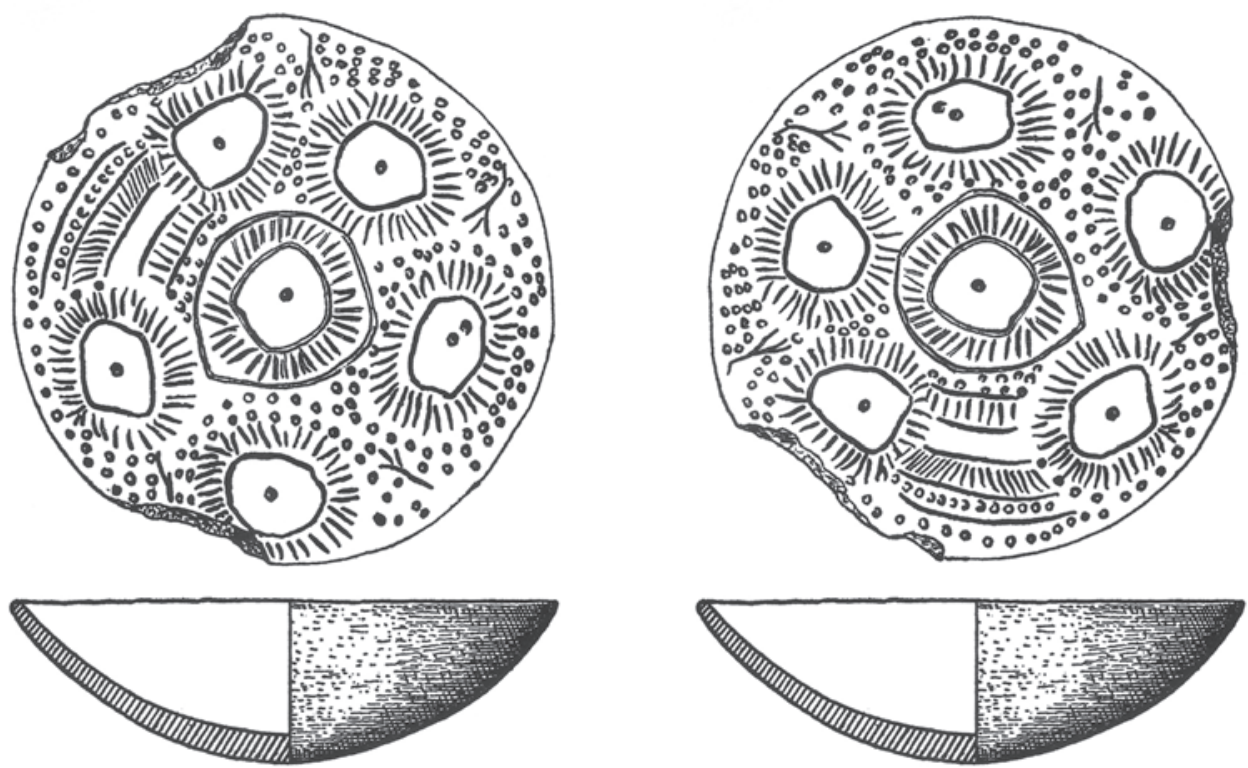

0

$5 \mathrm{~cm}$

Figura 30. Cuenco de la sepultura 17 de Los Millares. A la izquierda como fue publicado por Almagro y Arribas en 1963. A la derecha en la posición adecuada para su interpretación como bóveda celeste.

\subsection{La faz acuática del cielo es un concoide}

Hace dos décadas, R.A. Wells sostuvo que la imagen egipcia de Nut como bóveda celeste imitaría el diseño curvo con que la Vía Láctea se percibe desde el hemisferio norte (Wells 1992: 308309). Según esta hipótesis, el cuerpo femenino de Nut, representado desnudo y salpicado de estrellas en su cara ventral, se mostraba siempre incli- nado para recordar ese arco de nuestra galaxia (fig. 31). Sin embargo, el concepto egipcio de la Tierra como plataforma discoidal, unido a la experiencia proporcionada por las observaciones orbitales de los astros, implica necesariamente concebir el techo del mundo como una semiesfera que nos cubre. No hace falta, por tanto, acudir a la Vía Láctea como inspiradora formal del concoide celeste. Si el Sol, la Luna y los planetas

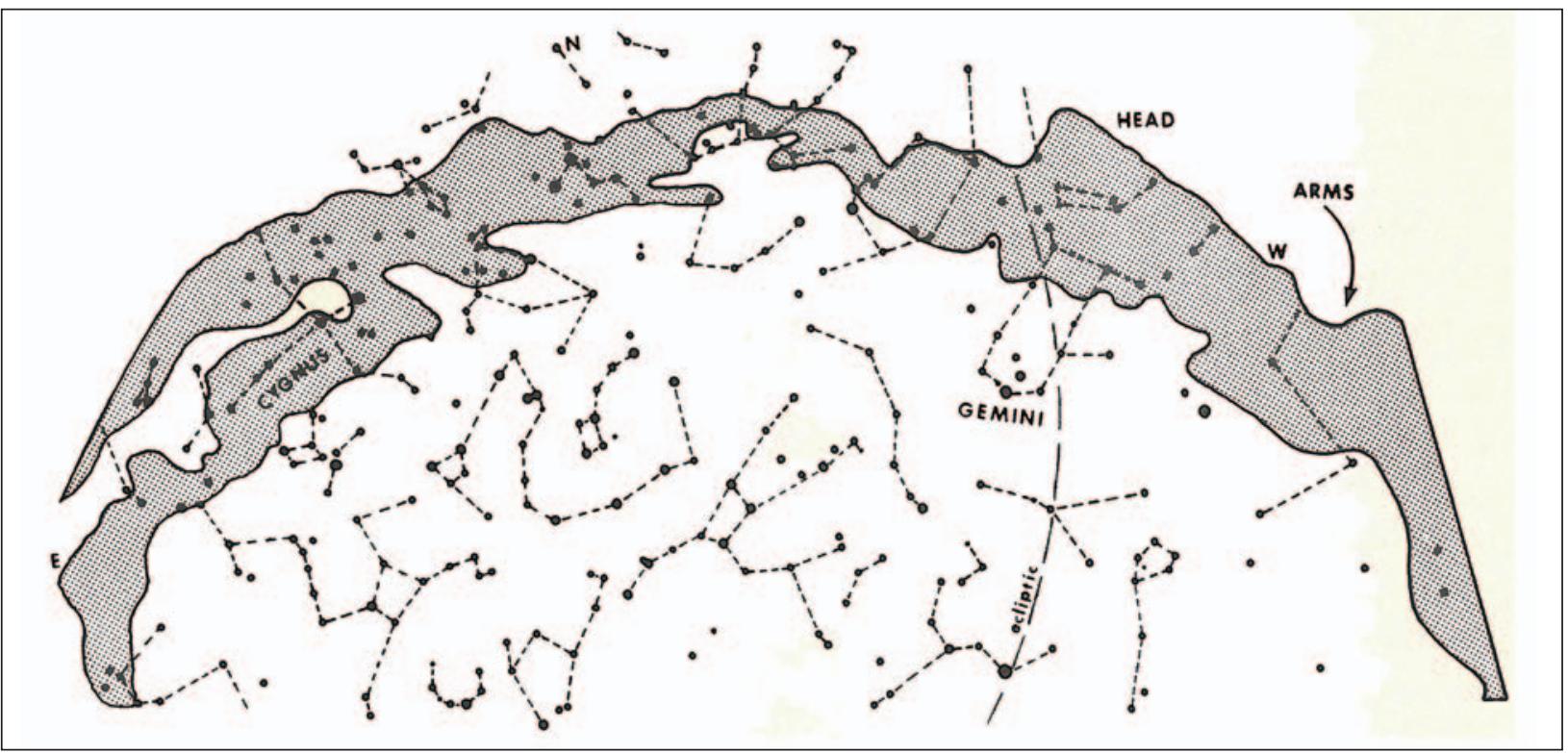

Figura 31. La Vía Láctea desde el hemisferio norte terrestre según Wells (1992), que para este autor habría servido al mundo egipcio como inspiración de la silueta curva de Nut. 
salen por una zona del horizonte y se ocultan más o menos por la opuesta, su recorrido dibujaba para los egipcios, como para otros muchos pueblos antiguos, un arco similar a media circunferencia o cercano a ella. Y, como ese camino curvo alcanzaba mayor o menor tamaño en función de la órbita aparente -real en el caso de la Luna- de cada cuerpo sobre el horizonte y en función de su ángulo cenital en las distintas jornadas de observación, el resultado era obligatoriamente una tupida red de rutas que terminaban confeccionando para cualquier observador terrestre una malla cóncava. Por este motivo, la mejor forma de plasmar plásticamente la cúpula del firmamento era mediante una concavidad hemisférica. En los casos más elementales, dicho seno podía ser un simple cuenco de cerámica, como ocurre en la mayor parte de los casos hispanos aquí estudiados. Sólo en algunas de las culturas que antropomorfizaron a las divinidades, la bóveda celeste, también divinizada, adquirió cuerpo humano, según ocurrió en Egipto con Nut (Billing 2002: 13-16). El diseño de esta diosa y su cuerpo arqueado son, pues, el simple resultado de sumar dos factores: esas mismas experiencias astronómicas y la proyección antropomorfa de su imagen (fig. 32).

De estas primeras reflexiones sobre el bosquejo general del cielo puede deducirse que aquellas poblaciones prehistóricas que lo plasmaron sobre la cara interna de un cuenco de cerámica participaron de concepciones cósmicas similares a las del mundo faraónico. Es más, ello implica necesariamente que concibieron la Tierra como una plataforma discoidal plana, cuyo centro era siempre, en esta visión precopernicana del sistema solar, el propio país donde esos observadores residían y desde el que percibían a diario ese vivir debajo de la bóveda de los cielos. No es por tanto casual que casi todas las representaciones astrales que conforman una "escena de cielo" se materializaran en escudillas de planta circular con diferentes aperturas, la mayor parte de las veces auténticas hemisferas. Así se concibió el firmamento también en otras muchas culturas antiguas, desde el Mediterráneo hasta el lejano Oriente. Sólo unas reflexiones más complejas acabaron por sumar esferas unas sobre otras, organizando la totalidad del cosmos como un conjunto de cuencos superpuestos y embutidos unos en otros, según se constata por ejemplo en la China antigua. Aquí, la escuela cosmológica Kai Thien, del siglo III a.C., pensó el mundo como un cuenco invertido encajado en el interior de otro de mayor tamaño, y de diseño similar, formado por la cúpula celeste. Encastrados de esta forma, ambos recipientes compartían un mismo eje, en torno al que se desenvolvían las orbitas de los astros. Entre los dos concoides, una capa de agua hacía las veces de lubricante sideral (Kragh 2008: 26).

El diseño hemisférico de la bóveda celeste no contradice en absoluto la idea de que el disco de Nebra, en este caso un círculo plano, sea también una representación de lo mismo. Frente a la cerámica, las dificultades que presenta el metal a la hora de confeccionar con él media esfera son evidentemente mayores. Es más, la elaboración de los distintos elementos celestes con películas de oro, incrustadas en este caso sobre estrechas ranuras, supondría un problema añadido. De ahí que se sacrificara el diseño abovedado en aras de su facilidad de fabricación y de sus posibilidades de menor deterioro.

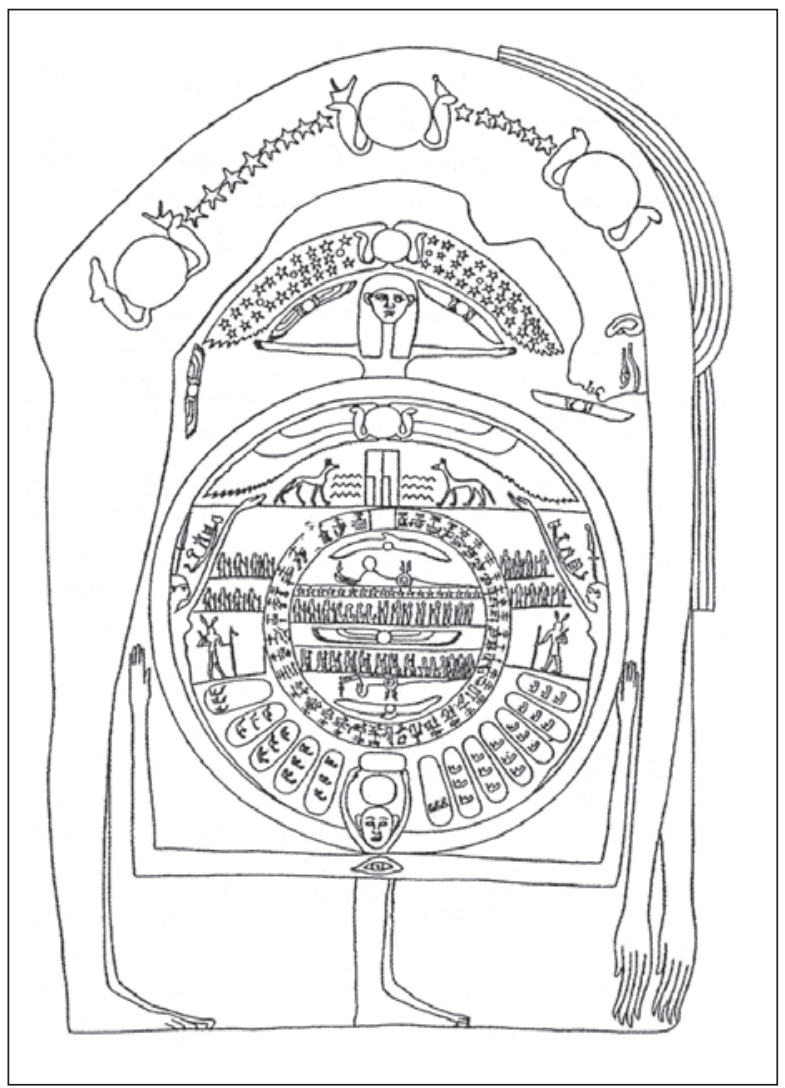

Figura 32. Imagen egipcia del mundo (disco plano) cubierto por Nut, la cúpula del firmamento. Según Lull (2004). 
Esta reflexión sobre la forma prehistórica de la bóveda celeste tiene que alertar necesariamente a los estudiosos del arte rupestre postpaleolítico. Aunque se conocen muchos casos de imágenes astrales en la pintura esquemática, la documentación disponible asocia a veces esas representaciones con pectiniformes y con determinados ramiformes. El simbolismo cósmico de estos paneles es evidente, más aún si se acepta la hipótesis de que algunos de estos últimos elementos son en realidad la esquematización formal de naves, y que representan por tanto la barca astral. Esas rocas pintadas constituyen a veces frisos planos, pero en otras ocasiones, y si la geología local lo permite, son verdaderas covachas u hornacinas hemisféricas. Un ejemplo paradigmático de esta característica se puede constatar en la estación de arte rupestre malagueña de Laja Prieta, donde los astros se pintaron al fondo de nichos cóncavos y entre un piélago de puntos que representarían las aguas cósmicas. En consecuencia, ni el azar ni el mayor grado de preservación que tales cavidades facilitan a los pigmentos son los únicos factores que explican esa ubicación. Para el mensaje que se quería transmitir con aquella concreta representación gráfica, la forma de la piedra suponía una de las razones principales a la hora de elegir el sitio, porque su diseño seguía fielmente la misma disposición arquetípica que mostraba la cúpula de los cielos (fig. 33).

\subsection{Capitán y marineros, o sobre la jerarquía celeste}

Los textos antiguos referidos a la bóveda celeste suelen mostrar casi siempre astros que ocupan rangos distintos. Un ejemplo bien conocido para la tradición judeocristiana occidental es el párrafo veterotestamentario alusivo a la creación del mundo, donde la Luna aparece nombrada después del Sol y antes que las estrellas (Génesis 1, 16; 37, 9); pero pueden citarse también otros muchos pasajes de la Biblia hebrea que recogen esta misma secuencia (Deuteronomio 4, 19; 17, 3; 33, 14; Josué 10, 12-13; 2 Reyes 23, 5; Job 25, 5; 31, 26; Salmos 8, 3; 72, 5; 74, 16; 148, 3; Eclesiastés 12, 2; etc.). En esa tradición literaria, los cuerpos de menor importancia, constitutivos

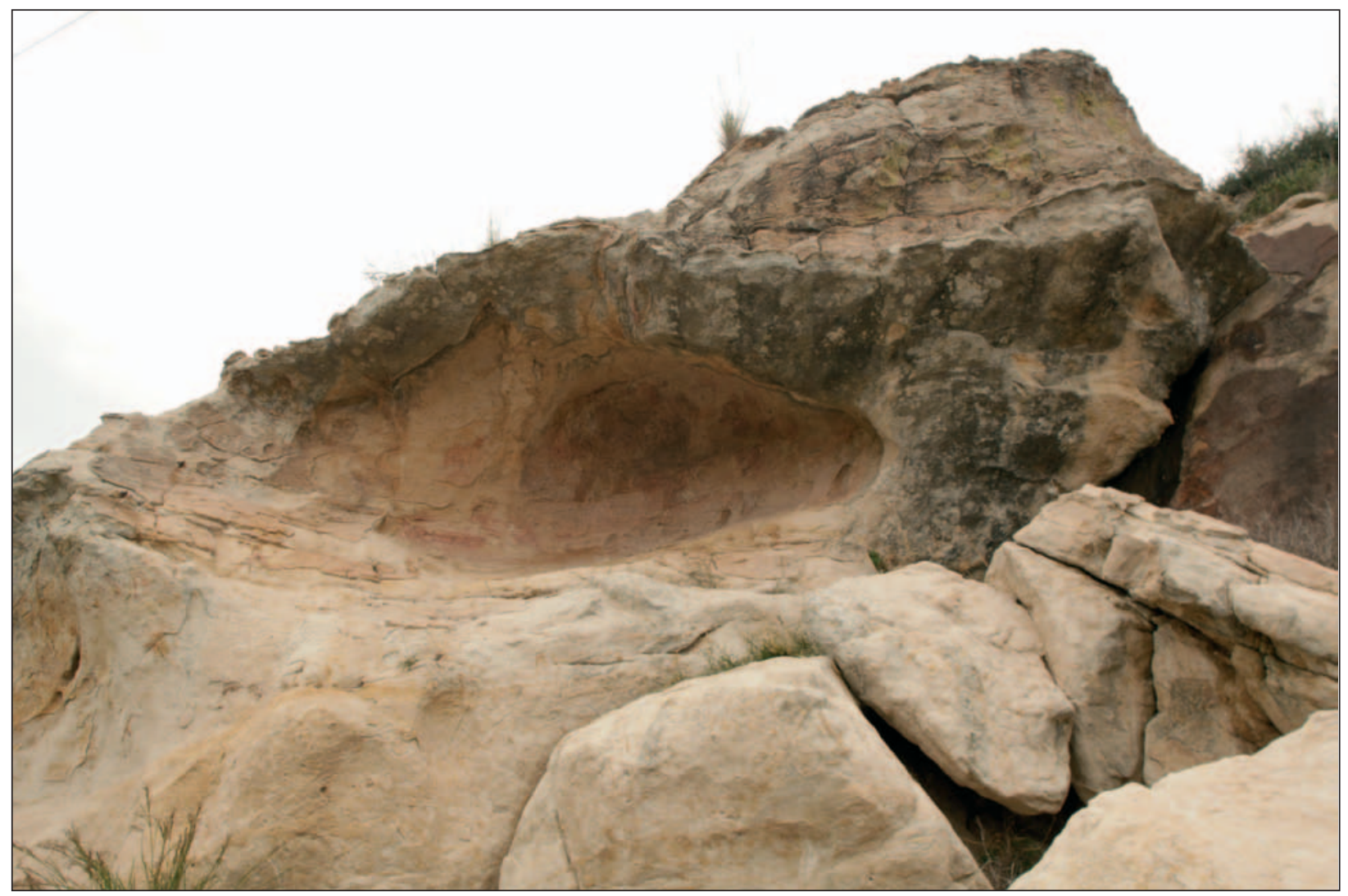

Figura 33. Recreación calcolítica de la bóveda celeste en una covacha hemisférica de Laja Prieta. Foto J. Pérez González publicada en Maura (2011). 
del fondo de estrellas fijas del universo y sobre los que se deslizan los planetas, se conocen genéricamente como asamblea de los cielos, coros o ejércitos celestiales (Deuteronomio 17, 3; Job 25, 3; Salmos 148, 2; Sofonías 1, 5; etc.). Es por tanto factible que ese mundo desigual de los astros quedara representado también con una escala de categorías en las vasijas prehistóricas en las que se plasmó el firmamento.

En el cuenco de Los Millares analizado en el apartado 4, uno de los dos astros muestra mayor número de ráfagas que el otro. Esto podría ser un indicador de la cantidad de luz emitida por cada uno, como ya sugerí. Pero el testimonio más claro lo ofrece en este sentido el techo astronómico del cuenco de la sepultura 17 de Los Millares (I de Almagro y Arribas 1963: lám. XVI, no 7). Dicho recipiente es sin duda una de las más completas representaciones hispanas de la bóveda celeste según ésta se concebía en época calcolítica. La composición está presidida por un astro central que se representa con mayor tamaño que el resto de los objetos luminosos y con rayos enmarcados por una doble corona circular. Este rasgo es exclusivo del astro central, por lo que no presenta dificultad alguna su identificación con el Sol. La forma de dicho dibujo solar cuenta con evidentes paralelos en otras imágenes coetáneas, especialmente en el arte esquemático. Alguna iconografía rupestre con temas astrales muestra al Sol prácticamente con el mismo diseño, como ocurre en la Cueva Bermeja de Monfragüe (Collado y García
Arranz 2005: 127). En cualquier caso, esta pintura resulta algo más compleja, sobre todo porque los rayos solares se distribuyen también por el círculo central que enmarca la orla periférica. En este disco interno el Sol del cuenco cerámico sólo muestra un punto realizado con técnica impresa (fig. 34).

Los demás astros presentes componen un grupo de categoría homogénea, pues no exhiben rasgos diferenciales que permitan establecer una jerarquización diáfana. Sólo uno de ellos, el situado en la parte superior izquierda del correspondiente al Sol, lleva en su interior dos puntuaciones cuando todos los demás muestran sólo una. Esto parece un simple accidente de fabricación debido tal vez a la excentricidad del posible primer punto colocado, que obligó al artesano a insertar un sustituto en posición más equilibrada. Por lo demás, el recurso de imprimir un punto en el círculo central se aplicó en otros muchos casos, por ejemplo en el vaso de la tumba XXI recogido en la figura 29.

El hecho de que sean cinco los astros que rodean al Sol no parece tampoco gratuito. En la Antigüedad eran sólo cinco los planetas conocidos, que fueron además fáciles de separar del fondo fijo del firmamento precisamente porque planeaban -de ahí su nombre en español- sobre el telón más inerte formado por las lejanas estrellas. De ser correcta tal identificación, se trataría de Mercurio, Venus, Marte, Júpiter y Saturno, ya que
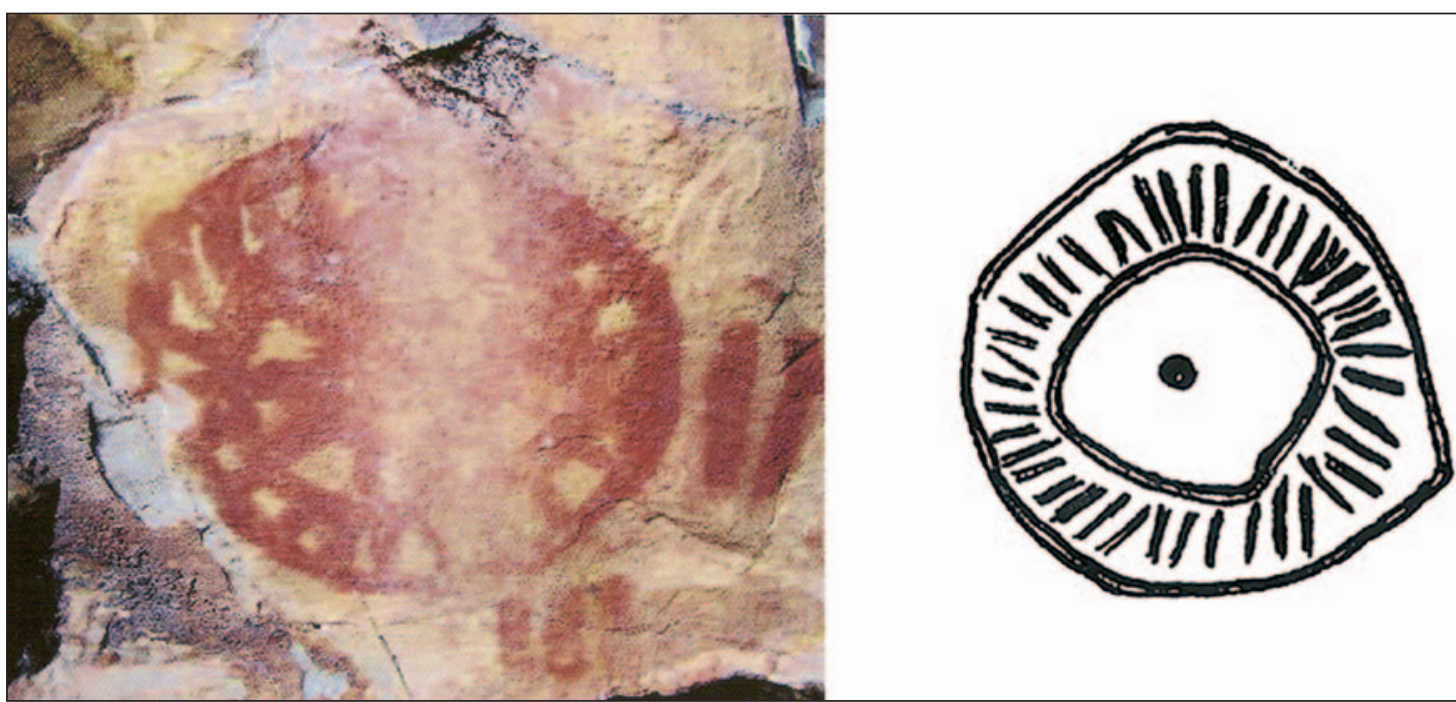

Figura 34. Iconos solares de Cueva Bermeja de Monfragüe, a la izquierda (Collado y García Arranz 2005), y del cuenco de la sepultura 17 de Los Millares, a la derecha. A distintas escalas. 
Urano y Neptuno, los más alejados del Sol, sólo se descubrieron tras el invento del telescopio ${ }^{10}$. Una parecida composición se repite, incluso con el mismo número de astros, en otro cuenco de Los Millares encontrado en la tumba 2 (Leisner 1943: lám. 14), si bien en este caso la mayor importancia de uno de los cuerpos celestes sólo puede deducirse del lugar central ocupado por uno de ellos, supuestamente el Sol (fig. 35). Estos testimonios sugieren que las sociedades calcolíticas occidentales interpretaron el cielo de manera muy parecida a como lo hicieron las culturas del Próximo Oriente asiático y de Egipto, tal vez porque sus conocimientos sobre el tema eran también similares. He aquí otra de las razones que permiten usar los datos de las zonas mejor conocidas hoy para explicar otros rincones de la cuenca mediterránea.

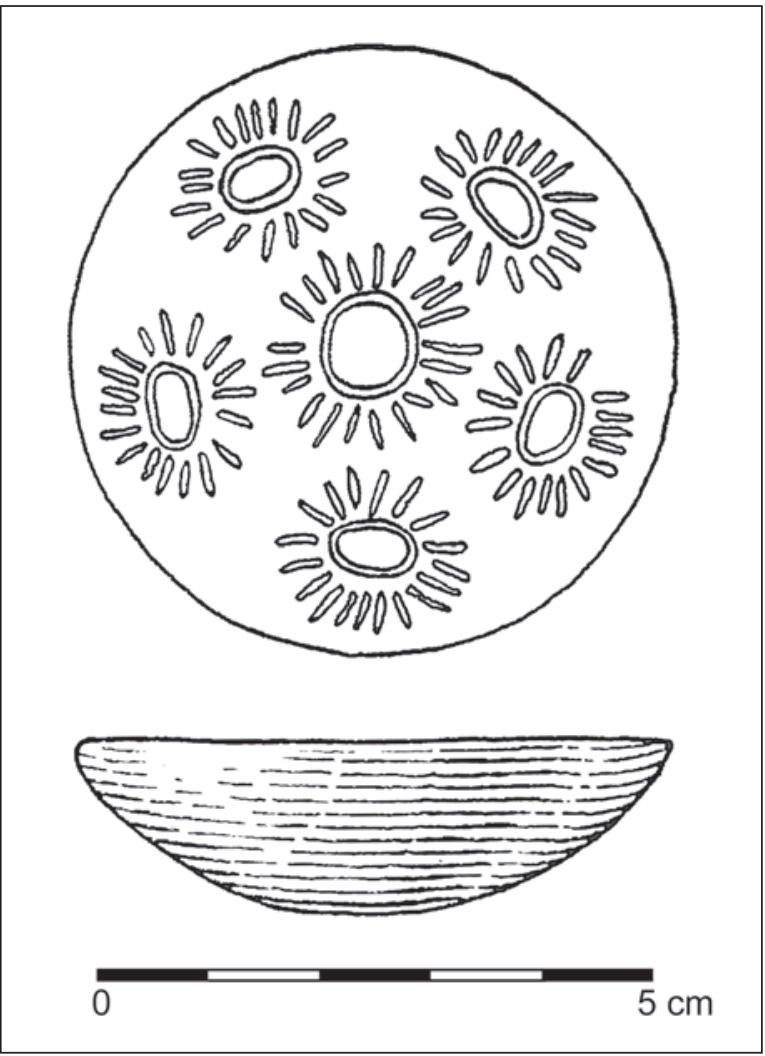

Figura 35. Cuenco de la Edad del Cobre hallado en la tumba 2 de Los Millares, según Leisner (1943).

El Sol (centro) acompañado por Mercurio, Venus, Marte, Júpiter y Saturno, los cinco planetas del sistema solar conocidos por el mundo antiguo.
En síntesis, y por lo que se refiere a los cuerpos celestes personificados, este cuenco de Los Millares habría representado sólo dos categorías: por un lado el Sol, por otro los cinco planetas más próximos a él exceptuada la Tierra. De nuevo debería concluirse, pues, que nuestro mundo no se concebía como esfera móvil, sino como una superficie circular quieta que puede ser imaginada como la base del cuenco una vez colocado éste boca abajo. En esa posición invertida, su simbolismo decorativo alcanzaba toda su plenitud. Las vasijas hemisféricas se convertían así en "techos astronómicos" al modo de los conocidos en el Egipto antiguo. Así pues, no es tampoco producto de ningún capricho ni de la casualidad que en ambos extremos del Mediterráneo las dos manifestaciones ocupen preferentemente ámbitos funerarios. En ese contexto, el cuenco de Los Millares ahora analizado mostraría alrededor del Sol a todos los planetas conocidos en la época, diferenciados en este caso de nuestra estrella en su diseño concreto y en su tamaño. En la visión geocéntrica de las culturas antiguas, esta disposición debe interpretarse como un mero recurso gráfico indicador de jerarquización, con el disco solar ubicado en el prestigioso y privilegiado lugar central. Esto impide deducir que en tiempos calcolíticos existiera un conocimiento copernicano del sistema orbital, con planetas girando en torno a su correspondiente estrella. Por otra parte, ya ha quedado dicho que los planetas podían representarse entonces con ráfagas de luz propia debido a que, al contrario que la cercana Luna, su distancia de la Tierra impedía reconocer el verdadero origen de su brillo.

\section{3. ¿Navegando a toda vela, o a remo?}

Si no fuera por los eslabones evolutivos secuenciados en algunos de los apartados anteriores, donde se parte de los barcos más naturalistas hasta llegar a los más esquemáticos, realmente supondría una dificultad extrema encontrar una nave en el cuenco de la sepultura 17 de Los Millares. Pero el lector tiene ya el ojo preparado para localizarla. La posición de este recipiente

10 Al redefinir el concepto de planeta, la Unión Astronómica 
adoptada para el presente artículo discrepa de las mostradas en casi todas las versiones hasta ahora publicadas del mismo. Dicho cambio está basado precisamente en haber identificado el motivo geométrico alusivo a la barca sagrada: unas incisiones horizontales ligeramente curvas que, en número de cinco, se ubican en la zona inferior. Entre algunas de esas líneas se disponen dos series de pequeños segmentos verticales que, en esta hipótesis, pueden aludir a otros componentes de la embarcación distintos del casco (fig. 36).

$\mathrm{Si}$ se interpretan estos recipientes astronómicos de Los Millares a partir de símbolos formalmente tan simples como los que contiene el disco de Nebra, no cabe otra posibilidad para este sector de la composición que ver aquí una plasmación profundamente abstracta de la barca solar. Al igual que en la pieza alemana y que en los demás casos ya tratados, la nave celeste también ocuparía ahora la zona inferior. Como tal embarcación, reducida gráficamente a unas simples líneas más o menos curvadas, la parte cóncava se dispondría de nuevo hacia arriba, la forma más lógica de ser representada; y de su borda partirían los remos hacia abajo. Pero en este esquema aparece otro sector de segmentos verticales por encima de lo ya descrito que no resulta de fácil identificación.
Es posible que se hubieran incluido dos navíos. En este caso el de arriba sería más pequeño que el de abajo tal vez sólo por razones de espacio en la distribución de los símbolos que ocupan la superficie interna del cuenco. Pero esta hipótesis parece débil a la luz de la cantidad de astros que forman parte de la composición. Dos barcas sagradas rebasarían las necesidades de un dios solar único, mientras que serían insuficientes para el Sol y los otros cinco astros que le acompañan. Tampoco parece probable que se trate de la fila de remos correspondiente a la otra borda del bote, más que nada porque en ese caso tales segmentos verticales paralelos deberían partir de la misma línea que representa la nave, como ocurre en Nebra, en el cuenco de la tumba 15 de Los Millares y en numerosos petroglifos europeos. Por tanto, es probable que se haya querido aludir aquí a un navío con remos (una sola fila) y a su vez con una vela recogida en la parte alta del mástil. De ser así, el conjunto superior de trazos correspondería a las cuerdas-guías que refuerzan la urdimbre del velamen. En cualquier caso, y como el mástil en realidad no aparece, resulta aún problemática tal hipótesis. Ésta debería además reconocer una última incisión inferior tal vez evocadora de la línea de flotación, y bajo la cual no

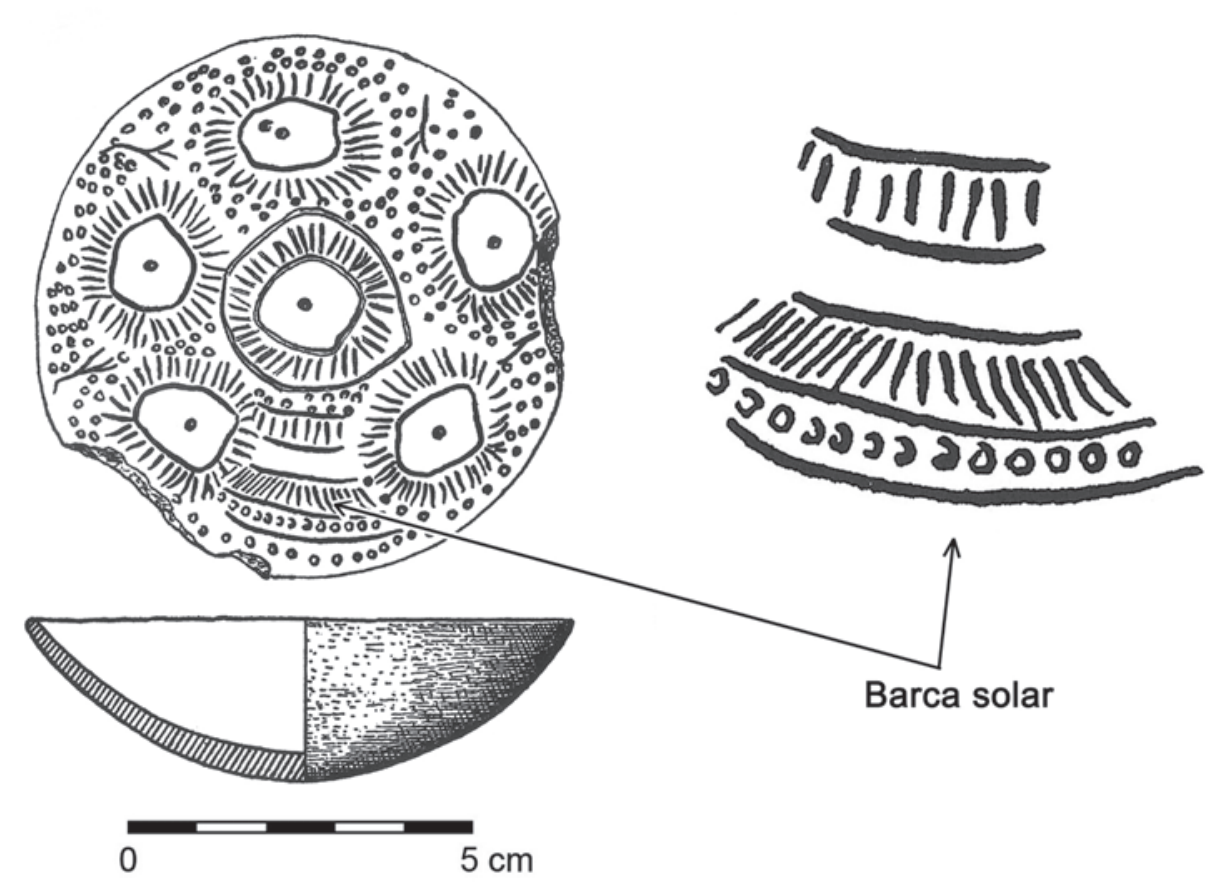

Figura 36. Cuenco de la sepultura 17 de Los Millares, con detalle destacado de la abstracción iconográfica de la barca solar. 


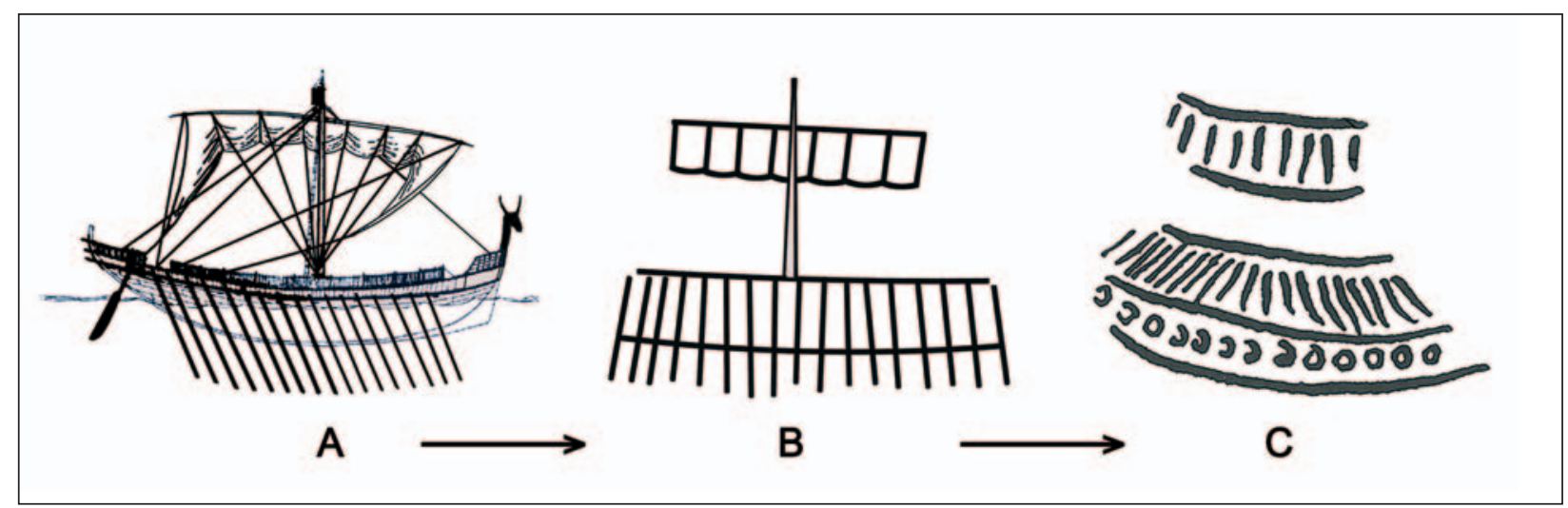

Figura 37. Posible evolución hacia el esquematismo de la barca solar representada en el cuenco de la tumba 17 de Los Millares.

se ven por tanto los remos. La figura 37 muestra el posible proceso evolutivo implícito en esta propuesta, desde una imagen más naturalista hasta la expresada realmente sobre el cuenco.

\subsection{En ruta por las aguas cósmicas}

Según la nueva lectura aquí defendida para los elementos que contiene el disco de Nebra, el navío representado en esta pieza alemana debe corresponder estrictamente a la barca solar. Las imágenes egipcias sobre el tema muestran una nave para cada divinidad si en la escena está presente más de un numen. Eso mismo sugiere el cuenco de Los Millares "decorado" con dos naves y dos astros visto en el apartado 4: que cada cuerpo celeste posee su propio vehículo. Según esta regla, y dado que el vaso de la sepultura 17 de Los Millares contendría una sola embarcación, ésta puede considerarse razonablemente la correspondiente al esteliforme central, imagen del Sol. Los demás astros, personificaciones de Mercurio, Venus, Marte, Júpiter y Saturno, estarían presentes sin sus respectivas barcas sagradas. Este distinto tratamiento puede ser también otra diferencia de rango a sumar a las ya señaladas. En cualquier caso, aunque se trate de una sola nave, ésta necesita desenvolverse por un medio acuoso.

La iconografía del océano primordial se llevó a cabo en el mundo egipcio básicamente mediante un campo de paralelas quebradas, es decir, con una especie de trama de líneas en zigzag. Así se dibujaron las aguas caóticas prístinas del universo (Nun) antes de que el demiurgo las dividiera en dos bloques, el de las terrestres y el alojado en la bóveda de los cielos. Se trata de una masa acuosa amorfa, que todavía no puede definirse ni como las terrestres (ondulaciones horizontales) ni como las celestes (agrupación de puntos), sino como un cuerpo compacto de paralelas quebradas verticales (fig. 38). Una vez separadas las dos aguas, las

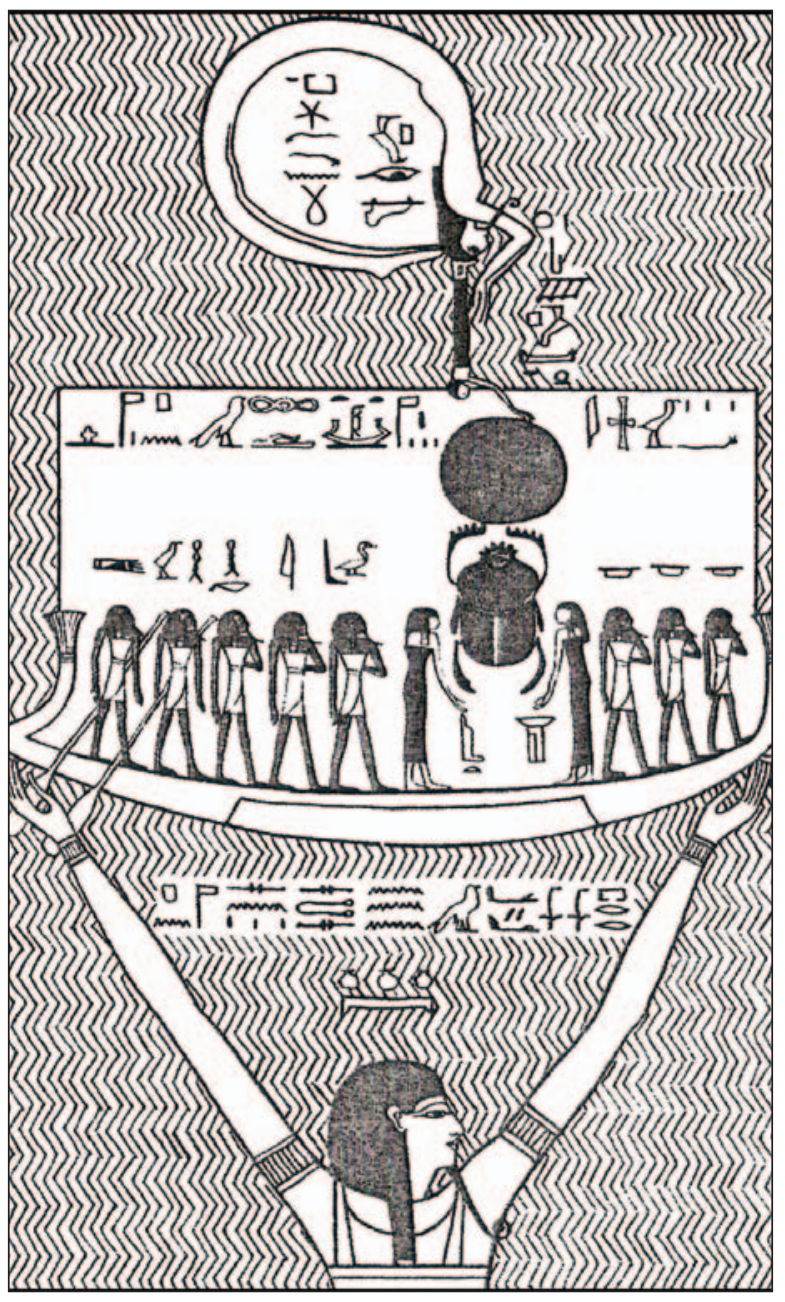

Figura 38. Las aguas primordiales de Nun, el universo caótico primitivo en el Egipto antiguo, se representan aquí mediante un campo de ondas verticales. 
de lo seco o parte inferior del mundo se plasmaron como la superficie del mar, recordando así las olas que el viento origina en cualquier plano líquido. Con líneas zigzagueantes u onduladas se representaron casi siempre en el mundo antiguo también los ríos y los lagos. Es más, la propia línea de flotación de las embarcaciones podía marcarse de esta forma, separado así la obra viva de la muerta en el conjunto del casco. Se trata de un viejo recurso gráfico usado ya, por ejemplo, en los citados barcos de Siros de la figura 3 .

Las aguas cósmicas eran otra cosa. No se podían materializar con líneas sinuosas porque no forman masas compactas ni se ven ondular como las terrestres. Cuando caen del cielo al llover, lo hacen como gotas esféricas. La mejor forma de aludir a ellas era por tanto mediante pequeñas marcas redondeadas, que en algunas figuras egipcias relativas a Nut llegan a ser circunferencias de tamaño reducido. En consecuencia, es por este mar cósmico de puntos por donde navegan los dioses-astros en sus barcas sagradas. En esta lógica, la misma necesidad de una embarcación para desplazarse por la cúpula del universo deriva precisamente de esa concreta concepción del cielo, un cosmos definible como una extensión acuosa de forma cóncava. Según esta argumentación, y teniendo como guía de nuevo las detalladas imágenes egipcias, no resulta difícil encontrar en el cuenco de la sepultura 17 de Los Millares la representación del agua celeste. Si cabe, aquí este reconocimiento puede ser más fácil incluso que en el disco de Nebra, sobre todo porque los puntos impresos que aluden a ella sólo se usaron para representar ese elemento concreto. En esta estructura mental, toda la superficie del firmamento dispone de agua. El Sol y sus astros-dioses compañeros ocupan la lámina completa del cielo visible. De hecho, el propio firmamento viene definido por el plano de deslizamiento de esos cuerpos, que pueden trasladarse en algunos casos desde cualquier punto del horizonte hasta su extremo opuesto a $180^{\circ}$. En razón de esta concepción de la bóveda celeste, las aguas cósmicas se distribuyen por todas las áreas de la cara interna del cuenco que no ocupan las representaciones astrales. Es más, de alguna forma se adaptan también a los alrededores de la barca solar, bajo la cual llegan a formar una sólida base conformada por una secuencia horizontal de puntuaciones muy apretadas, como si se hubiese querido representar una marca de flotación que en ningún caso podía plasmarse aquí, por tratarse de aguas cósmicas y no terrestres, mediante ondulaciones o líneas en zigzag (fig. 39).

\subsection{Tormenta en alta mar}

Para muchas culturas del mundo antiguo el rayo fue símbolo del poder de la divinidad. Las experiencias negativas que las descargas eléctricas de las tormentas han originado en la humanidad han debido ser numerosas. Este fenómeno pudo ser tan incomprendido como temido por los grupos prehistóricos. Las razones de este miedo son evidentes. El Sistema de Detección Mundial de Meteorología cifra en unos ocho millones los rayos que cada día se producen en nuestro planeta. Sólo en la Península Ibérica, el 2 de julio de 2010 cayeron 2088 en seis horas según la Agencia Estatal de Meteorología. Un rayo mide entre 2 y 5 $\mathrm{cm}$ de diámetro, llega a la superficie terrestre a $94.000 \mathrm{~km} / \mathrm{s}$ y suele alcanzar una intensidad eléctrica de 10.000 a 30.000 amperios. Su efecto sobre el terreno no se limita al peligro evidente para el organismo vivo sobre el que caiga; en ocasiones origina fulguritas, masas de tierra vitrificadas por unas temperaturas que oscilan entre los 17.000 y los $39.000{ }^{\circ} \mathrm{C}$ (González Laguna y otros 2011: 8). Todos estos rasgos, unidos al desconocimiento milenario de sus causas en tiempos pasados, constituyen buenos argumentos para que la Antigüedad viera en el rayo un arma letal en manos de divinidades enfurecidas.

Las características descritas hacen también del rayo un fenómeno singular, y por tanto digno de ser recogido en la iconografía de la bóveda celeste. Más aún cuando no se tienen nociones claras sobre la distancia existente entre el observador y los distintos fenómenos y cuerpos celestes percibidos, o incluso sobre la separación de tales hechos entre sí. Aunque hoy distinguimos bien entre elementos meteorológicos y acontecimientos astronómicos, esta diferenciación sólo puede percibirse cuando se elaboran cálculos aritméticos lógicos y medianamente precisos sobre sus distancias hasta el punto de observación. Si el agua de lluvia podía interpretarse como parte del 

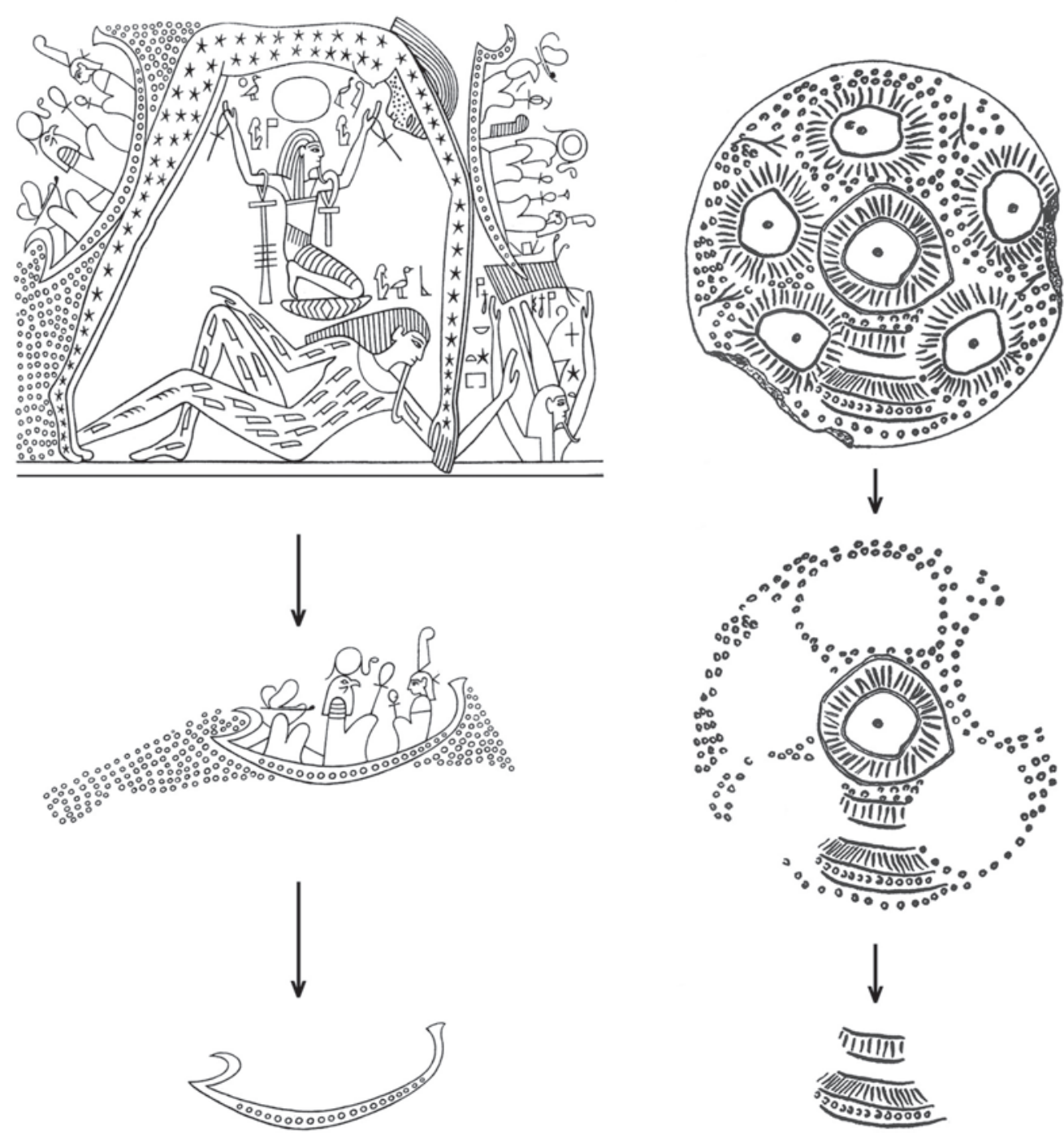

Figura 39. Imágenes de la bóveda celeste en Egipto (izquierda) y en el Calcolítico hispano (derecha). Las aguas cósmicas se representan en ambos casos con gotas esféricas. Por tanto, la línea de flotación debe expresarse en las correspondientes barcas solares como una hilera de puntos.

piélago cósmico -y de ahí que este último se imaginara como un conjunto de innumerables esferitas- no existen razones para que el rayo se excluyera del lote de elementos a representar en las composiciones más complejas. La confusión entre lo atmosférico y lo astronómico ha quedado fosilizada en algunos términos usados aún en estos campos científicos. Por eso, llamamos fenómenos meteorológicos y meteoritos a cosas que en principio proceden de estos ámbitos hoy bien separados. Ambos términos derivan de una misma raíz griega que significa simplemente elevado en el aire.

En el elenco iconográfico del Próximo Oriente antiguo, en especial durante el segundo milenio
a.C., el rayo aparece normalmente como manifestación de la omnipotencia divina; de ahí que se incluya en la panoplia más mortífera de los dioses. Por este motivo, cuando las divinidades adquieren forma humana pueden portar un rayo en la mano, apareciendo así como señores de la tormenta. En las ocasiones más explícitas y realistas, como ocurre con el Baal cananeo del Louvre, el rayo adquiere forma de báculo acabado por su extremo inferior en punta de jabalina y por arriba como arbusto ramificado (fig. 40). Esta iconografía supone una de las más naturalistas, y tiene otros claros paralelos en el mundo oriental que no siempre se han interpretado bien al confundirse el rayo con una simple lanza (Cornelius 


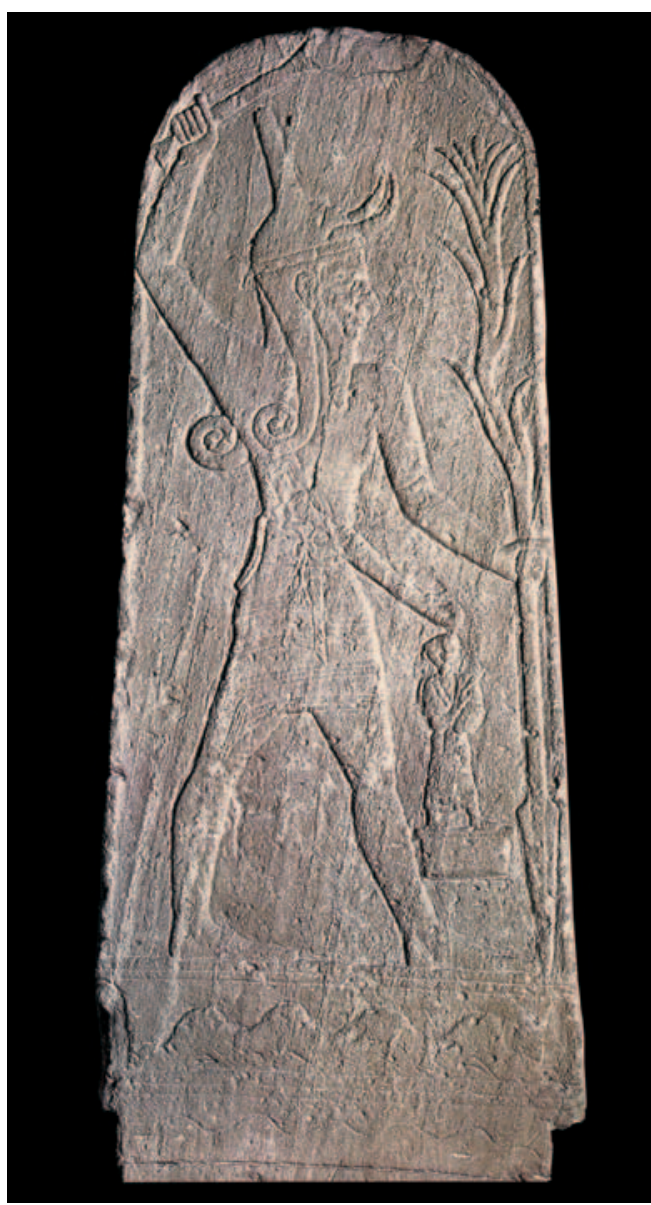

Figura 40. Baal con rayo en su mano izquierda. Museo del Louvre.
1994: 135-138, 172 y 175, lám. 33-BR1, 45-BM5 y 47-BM9). Pero otras veces ese elemento castigador acaba convertido en una herramienta con diversas púas -normalmente tres- transformada en una suerte de bieldo. Desde esta hipótesis evolutiva que reconoce una tendencia a la esquematización, es posible que el tridente de Poseidón no sea más que el resultado de este cambio iconográfico, cuyo significado originario pudo haberse olvidado cuando en época romana Neptuno se representa en ocasiones con un tridente empleado como simple arpón de pesca. De hecho, los especialistas en mitología e iconografía clásicas no saben si algunas imágenes griegas de cronología relativamente arcaica se refieren a Zeus con el rayo o a Poseidón con el tridente. En cualquier caso, el hecho de que en la cultura grecorromana este dios tuviera a su cargo el dominio del mar, lo hizo igualmente dueño de la tempestad, y por ende amo de la tormenta y del rayo. Convertido también en una especie de tridente, doble en algún caso, el rayo aparece ya en el Adad acadio y en el Teshub hurrita e hitita (fig. 41).

Desde esta documentación, los elementos geométricos que el cuenco de Los Millares muestra, hasta cuatro veces, separando los astros periféri-
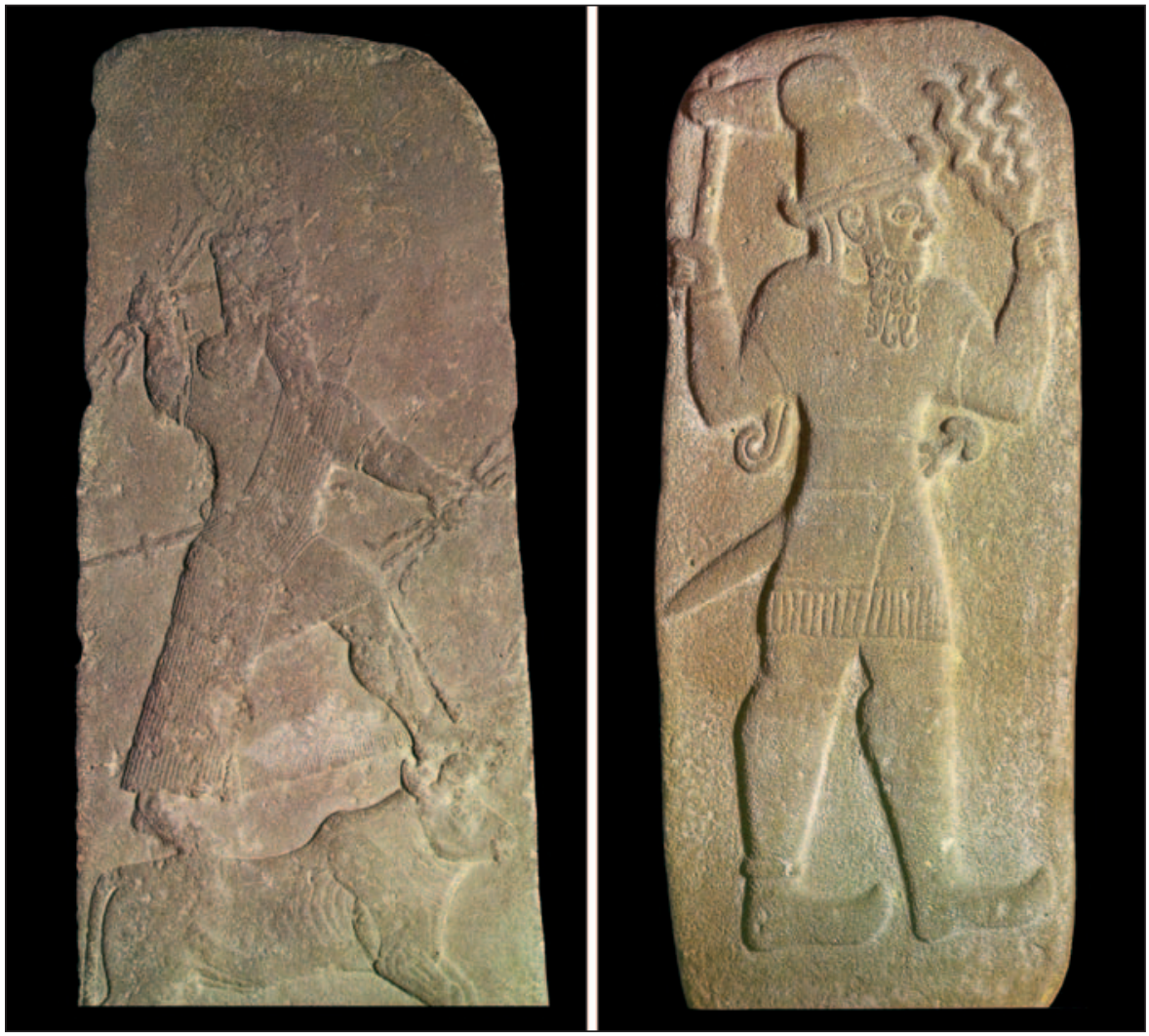

Figura 41. Adad (izquierda) y Teshub (derecha) representados con rayos de iconografía evolucionada, convertidos ya en algún caso en tridentes. 
cos, pueden interpretarse como representaciones muy esquemáticas de rayos. Éstos se habrían imaginado cayendo sobre la línea del horizonte, en este caso el borde del recipiente cerámico visto en posición invertida. Y, como el cuenco mismo supondría la representación del cielo abovedado, esas incisiones deben leerse con su parte ramificada hacia arriba, de forma similar al rayo que lleva en su mano izquierda el relieve del Museo del Louvre alusivo a Baal (fig. 42).

\section{Divinos pasajeros}

La elección del oro para representar en el disco de Nebra todos los elementos que tienen que ver con las concepciones cósmicas de la época no es producto ni del azar ni de un mero afán de prestigiar la pieza. Por estar esos cuerpos celestes elaborados en dicho metal, todos ellos constituirían entes divinos, incluidas las aguas situadas por encima de la bóveda del firmamento y las marcas del recorrido cíclico y horizontal de los astros en sus ortos y ocasos, es decir, las chapas curvas que podrían denominarse arcos de declinación. Diversos textos orientales, por ejemplo El Libro de los Muertos o algún párrafo bíblico entre otros, expresan con claridad esta peculiaridad del oro como emblema de las divinidades y como materia reservada a ellas. Así, en el papiro de Nebseni, procedente de Menfis y datado en el siglo XV a.C., puede leerse: "Tu cabeza, oh mi Señor, se adorna con la trenza de una mujer de Asia... tu pelo resplandece de lapislázuli; la parte superior de tu cara es como el resplandor de $\mathrm{Ra}$; tu rostro está cubierto de oro y Horus lo ha engastado con lapislázuli..." (Wengrow 2007: 27). Y en Ageo $(2,8)$ se afirma sobre el dios de Israel: "¡Mía es la plata y mío el oro! oráculo de Yahveh Sebaot".

Fruto de esa tradición milenaria, en época romana este metal era aún una típica ofrenda para la divinidad en algunas zonas del Imperio: "Al ver la estrella se llenaron de inmensa alegría. Entraron en la casa; vieron al niño con María su madre $\mathrm{y}$, postrándose, le adoraron; abrieron luego sus cofres y le ofrecieron dones de oro, incienso y mirra" (Mateo 2, 10-11). He aquí, además, un regalo para una divinidad cuyo nacimiento se identifica con el de un astro, en línea de nuevo con esa misma herencia mítica ya milenaria en tiempos de Cristo.

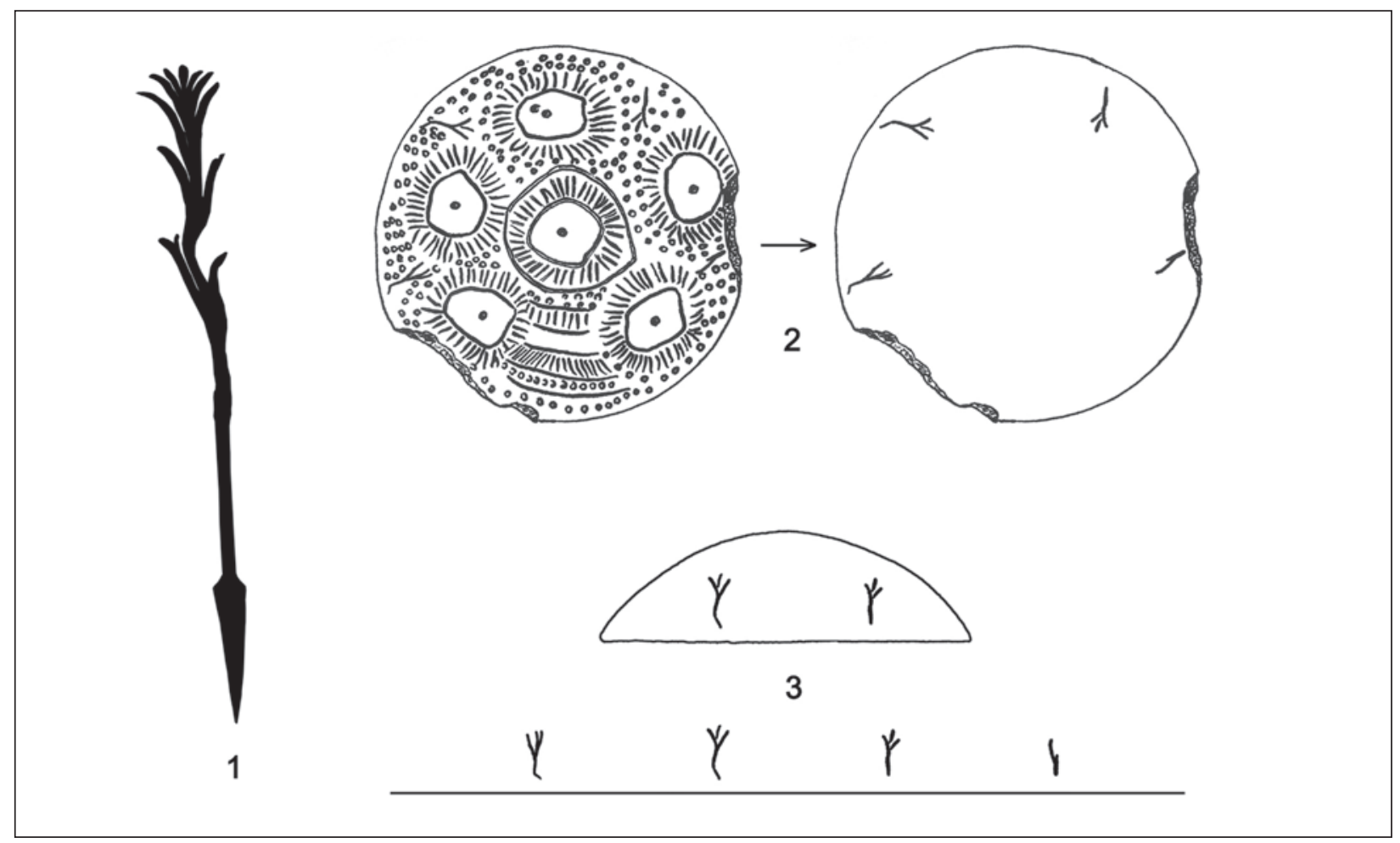

Figura 42. Comparación del rayo del Baal cananeo del Museo del Louvre (1) con los rayos representados como pequeños ramiformes incisos en el interior del cuenco del enterramiento 17 de Los Millares (2). La composición podría leerse como una secuencia de descargas eléctricas que caen sobre la línea del horizonte, en este caso el propio borde de la escudilla una vez imaginada como bóveda celeste, es decir, en posición invertida (3). 
En consecuencia, cuando hoy se sostiene que las poblaciones prehistóricas y antiguas estudiaban un tipo de astronomía especialmente ligada al plano religioso, de alguna forma se tergiversa el sentido de aquellas experiencias. De hecho, el análisis de tipo emic que aquí he propuesto cobraría todo su sentido si cada vez que aparece el término "astro" en este artículo se cambiara por la palabra "dios". Que sepamos, fue el griego Anaxágoras quien por vez primera definió el Sol como una roca incandescente (Schneider y Sagan 2008: 58). Comenzó así a desprenderlo del carácter sagrado que poseyó hasta entonces, evidente con toda su fuerza en el nombre que recibía entre los egipcios: "divino ojo de fuego" (Lull 2004: $170)^{11}$. Por eso, cuando en estas culturas antiguas los especialistas en el culto estudiaban los movimientos de los distintos objetos celestes, posiblemente no tenían conciencia de estar haciendo más que teología. Más que manifestaciones o creaciones cósmicas debidas a las manos y la voluntad de dioses todopoderosos, los astros eran las divinidades mismas. En este terreno, la evolución del pensamiento humano en el ámbito mediterráneo no habría consistido en un proceso de divinización de meros cuerpos físicos nacido en la Prehistoria y culminado en la Antigüedad; más bien habría ocurrido todo lo contrario, una desacralización progresiva de dioses residentes en el cielo que han acabado hoy rebajados a la categoría de simples astros. De ahí que el oficio actual de astrónomo sea en realidad la derivación evolutiva de arcaicos ministerios sacerdotales (Escacena 2006).

Esta identificación inicial de los elementos celestes con las divinidades explica multitud de gestos litúrgicos que han durado hasta la actualidad en diversas religiones. Que la posición de orar sea dirigir los brazos -y a veces también la mirada- hacia lo alto, no puede tener su razón de ser más que en este hecho. Por tal motivo, si los "orantes" de la pintura parietal macroesquemática del Levante español aluden realmente a este acto de elevar plegarias a los númenes cósmicos, como así parece, la identificación de los dioses con los astros constituiría en la Península Ibérica un

11 Aunque entre los cananeos el Sol también fue divinizado (Shapash), se alude a él en ocasiones como "fuego del cielo" hecho real desde el Neolítico antiguo. Esas figuras rupestres tienen su correspondencia coetánea en decoraciones sobre cerámica que certifican su fecha más vieja en el V milenio a.C. al menos (Martí y Hernández 1988: 19 ss.). En cualquier caso, y por lo que se refiere a la cronología de los testimonios aquí estudiados, esas mismas actitudes rituales pueden observarse en numerosas figurillas esquemáticas de arte mobiliar con brazos alzados, esta vez del Calcolítico ibérico (fig. 43).

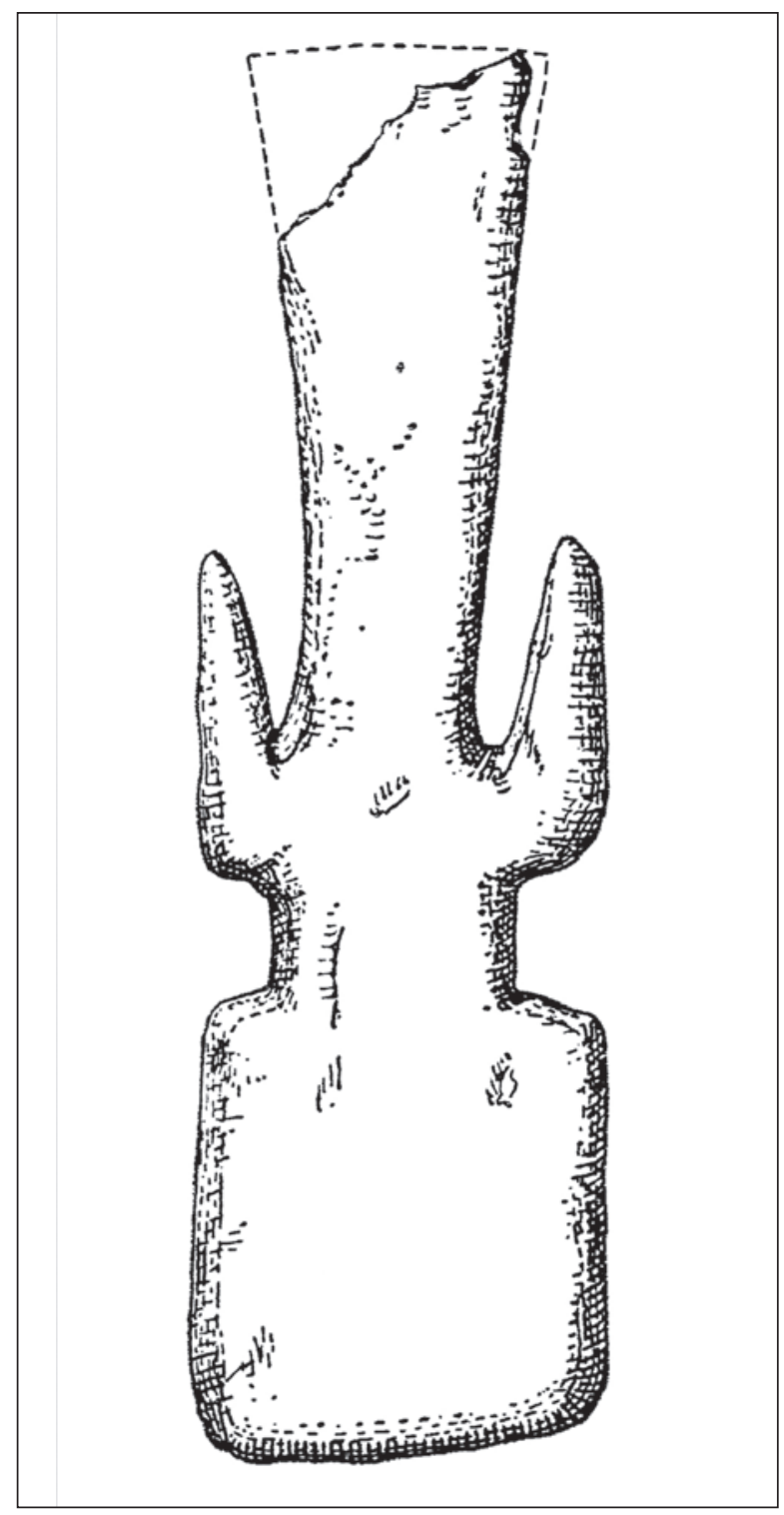

Figura 43. Figurilla antropomorfa esquemática procedente de Tíjola (Almería), según Leisner (1943). Los brazos alzados al cielo sugieren su interpretación como orante. 


\section{Viaje Concluído. ECHEMos El ANCLA}

La experiencia conseguida en el estudio de la cerámica simbólica obliga a investigar en el significado de sus temas decorativos situándolos siempre en su contexto compositivo concreto. Por tanto, hay que rechazar generalizaciones que lean siempre lo mismo cada vez que un motivo más o menos geométrico se repite. De esta forma, ni todo punto impreso sobre la arcilla puede considerarse una gota de agua cósmica, ni cualquier bóvido abstracto tiene que simbolizar necesariamente un barco con prótomo de toro en la proa. Traducir el mensaje de estas representaciones, ya sea en petroglifos, en pintura rupestre o en ornamentos cerámicos, exige un esfuerzo por aislar elementos para individualizarlos y reconocerlos, y más tarde la labor de volverlos a juntar con el propósito de que se expliquen mutuamente. Es por tanto la asociación global la que proporciona las claves de su posible lectura. Aún así, los casos trabajados para este artículo aconsejan que los prehistoriadores estén más abiertos a reconocer mensajes simbólicos donde muchas veces se han visto sólo decoraciones geométricas. Pero les exige también un esfuerzo por concretar el significado posible de los mensajes. Ya no basta con asumir que se trata de representaciones simbólicas. Si lo fueran, esta conclusión debe obtenerse de haber captado previamente su contenido. El proceso contrario, es decir, aceptar una lectura general que no puede ser apoyada por casos individuales bien desmenuzados, supone seguir cayendo en otro más de los muchos axiomas que medran en la ciencia arqueológica, con el consiguiente menoscabo epistémico de ésta.

A lo largo de este artículo hemos comprobado cómo el mundo calcolítico de la Península Ibérica participó de unos saberes cósmicos y de una interpretación del cielo similar a la que poseyeron otras culturas del Mediterráneo. Es más, los datos sugieren con relativa claridad que tales ideas estaban ya configuradas en sus nociones básicas durante el Neolítico, seguramente como acervo cultural común de las gentes impli-

\footnotetext{
${ }^{12}$ La cursiva corresponde al título en castellano de uno de sus libros más recientes (Hawking 2011 [2001]).
}

cadas en la expansión de la vida agropecuaria. Si las sociedades calcolíticas perfilaron más dichos conocimientos y los asociaron al mundo funerario, cuestión que se observa tanto en los ajuares de las tumbas como en las orientaciones astronómicas de éstas, tal vez fue porque llegaron a creer que el cielo era el destino ultraterreno del hombre. De ahí su interés por representar gráficamente su visión del mismo y por investigar sus rincones, un objetivo que todavía mueve muchas voluntades e inmensos recursos económicos.

Desde la vanguardia del conocimiento científico actual, que concibe el cosmos como una membrana, Stephen Hawking logró hace poco, para quienes no somos expertos en astrofísica, una explicación que condensaba todo El universo en una cáscara de nuez $z^{12}$. Pero hace ya casi cinco mil años, la gente de la Edad del Cobre de Los Millares y de otros rincones del mediodía ibérico consiguió también introducir la piel acuosa y hemisférica de su firmamento en un cuenco de cerámica.

\section{Bibliografía}

ACOSTA, P. (1968): La pintura rupestre esquemática en España. Universidad de Salamanca, Salamanca.

ALMAGRO, M.; ARRIBAS, A. (1963): El poblado y la necrópolis megalíticos de Los Millares (Santa $\mathrm{Fe}$ Mondújar, Almería) (Bibliotheca Praehistorica Hispana III). CSIC, Madrid.

ALMAGRO-GORBEA, M. (1988): "Representaciones de barcos en el arte rupestre de la Península Ibérica. Aportación a la navegación precolonial desde el Mediterráneo oriental", Congreso Internacional «El Estrecho de Gibraltar», tomo I: 389-398. UNED, Madrid.

ALONSO, F. (1974): "Hallazgo de un petroglifo con representaciones esquemáticas de embarcaciones de la Edad del Bronce", Zephyrvs XXV: 295-308.

APARICIO, A.; ESTEBAN, C.; BELMONTE, J.A. (2000): "Las bases astronómicas", en J.A. Belmonte (coord.), Arqueoastronomía Hispana: 19-65. Equipo Sirius, Madrid. 
ARRIBAS, A.; MOLINA, F. (1987): "New Bell Beaker discoveries in the Southeast Iberian Peninsula", en W.H. Waldren y R.C. Kennard (ed.), Bell Beaker discoveries of the western Mediterranean. Definition, interpretation, theory and new site data (BAR Intern. Series 331, I): 129-146. Oxford.

AUBET, M.E. (1994): Tiro y las colonias fenicias de Occidente. Crítica, Barcelona.

AVENI, A.F. (1991): Observadores del cielo en el México antiguo. Fondo de Cultura Económica, México D.F.

BELMONTE, J.A. (1999): Las leyes del cielo. Astronomía y civilizaciones antiguas. Temas de Hoy, Madrid.

BENDALA, M. (1976): La necrópolis romana de Carmona (Sevilla). Diputación Provincial de Sevilla, Sevilla.

BILLING, N. (2002): Nut. The goddess of life in text and iconography (Uppsala Studies in Egyptology 5). Uppsala University, Uppsala.

BOSCH, P. (1966): “Cultura megalítica portuguesa y culturas españolas", Revista de. Guimarâes 76: 249-306.

CANTALEJO, P.; MAURA, R.; BECERRA, M. (2006): Arte rupestre prehistórico en la Serranía de Ronda. La Serranía, Ronda.

CARDOSO, J.L.; ANDRÉ, M.V. (2005): “Um Cometa na Pré-História portuguesa: a taça do povoado calcolítico do Outeiro de S. Mamede (Bombarral) e o imaginário colectivo ligado a tais corpos celestes", Al-Madan 13: 36-47.

CHAPMAN, R. (1991): La formación de las sociedades complejas. El Sureste de la Península Ibérica en el marco del Mediterráneo occidental. Crítica, Barcelona.

CONGDOM, L.O. (2000): “A rare solar display depicted in the tomb of Meryra at El Amarna", Amarna Letters 4: 44-59.

COLEMAN, J.E. (1985): “«Frying pans» of the Early Bronze Age Aegean", American Journal of Archaeology 89: 191-219.

COLLADO, H. (2009): "Propuesta para la clasificación funcional y cronológica del arte rupestre esquemático a partir del modelo extremeño", en R. Cruz-Auñón y E. Ferrer (coord.), Estudios de prehistoria y arqueología en homenaje a Pilar Acosta Martínez: 89-108. Universidad de Sevilla, Sevilla.
COLLADO, H.; GARCÍA ARRANZ, J.J. (coord.) (2005): Corpus de Arte Rupestre en Extremadura. I, Arte Rupestre en el Parque Natural de Monfragüe. Junta de Extremadura, Badajoz.

CORNELIUS, I. (1994): The iconography of the Canaanite gods Reshef and Bacal. Late Bronze And Iron Age I periods (c. 1500-1000 BCE). University Press Fribourg Switzerland, Fribourg.

DAMS, L. y M. (1983): “Quelques considérations sur l'art rupestre schématique d'Andalosie", Zephyrvs XXXVI: 187-192.

DEL AMO, M. (1974): "Las grabados rupestres de «Los Aulagares» (Zalamea la Real, Huelva)", en E. Ripoll y M. Llongueras (ed.), Miscelánea Arqueológica. XXV Aniversario de los Cursos Internacionales de Prehistoria y Arqueología en Ampurias (1947-1971), tomo I: 69-86. Diputación de Barcelona, Barcelona.

ELDREDGE, N.; GOULD, S.J. (1972): "Punctuated equilibria: an alternative to phyletic gradualism", en T.J.M. Schopf (ed.), Models in Paleobiology: 82-115. Freeman and Cooper, San Francisco.

ESCACENA, J.L. (2006): "Allas el estrellero, o Darwin en las sacristías", en J.L. Escacena y E. Ferrer (ed.), Entre Dios y los hombres: el sacerdocio en la Antigüedad (Spal Monografías VII): 103-156. Universidad de Sevilla, Sevilla.

ESCACENA, J.L. (2007): "El dios que resucita: claves de un mito en su primer viaje a Occidente", en J.J. Justel y otros (ed.), Las aguas primigenias. El Próximo Oriente Antiguo como fuente de civilización (Actas del IV Congreso Español de Antiguo Oriente Próximo): 615-651. Instituto de Estudios Islámicos y del Oriente Próximo, Zaragoza.

ESCACENA, J.L. (2009): "La Égersis de Melqart. Hipótesis sobre una teología solar cananea", Complutum 20 (2): 95-120.

ESCACENA, J.L. (2011): "Variación identitaria entre los orientales de Tartessos. Reflexiones desde el antiesencialismo darwinista", en M. Álvarez (ed.), Fenicios en Tartessos: nuevas perspectivas (BAR Intern. Ser. 2245): 161-192. Archaeopress, Oxford.

ESCACENA, J.L.; GAVILÁN, B.; MAS, M. (2009): "Sobre barcos y astros. En torno al imaginario cósmico de la Prehistoria reciente en el mediodía ibérico", en R. Cruz-Auñón y E. Ferrer (coord.), Estudios de prehistoria y arqueología en homenaje a Pilar Acosta Martínez: 255-277. Universidad de Sevilla, Sevilla. 
GARCÍA SANJUÁN, L. (2011): “The numerical chronology of the megalithic phenomenon in southern Spain: progress and problems", Menga Monográfico 1: 121-142.

GARDINER, A. (1982): Egyptian grammar. Oxford University Press, Oxford.

GAVILÁN, B. (1989): "Paralelismo entre la decoración cerámica y el arte esquemático parietal: vasija de la Cueva de la Murcielaguina (Priego de Córdoba)", XIX Congreso Nacional de Arqueología, vol. II: 229-236. Universidad de Zaragoza, Zaragoza

GONZÁLEZ GARCÍA, A. C. (2004): “El disco de Nebra”, Investigación y Ciencia 335: 82-83.

GONZÁLEZ GARCÍA, A. C. (2009): “Análisis estadístico de las orientaciones de los megalitos de la Península Ibérica”, Complutum 20 (2): 177-186.

GONZÁLEZ LAGUNA， R.; LOZANO, R.P.; MARTÍN, T. (2011): "Rayos, truenos y fulguritas”, Investigación y Ciencia 418: 8-9.

GUERRERO, V.M. (1993): Navíos y navegantes en las rutas de Baleares durante la Prehistoria. El Tall, Palma de Mallorca.

GUERRERO, V.M. (1998): "Los mercantes feniciopúnicos en la documentación literaria, iconográfica y arqueológica", en B. Costa y J. H. Fernández, Rutas, navíos y puertos fenicio-púnicos (XI Jornadas de Arqueología Fenicio-Púnica): 61103. Museo de Ibiza y Formentera, Ibiza.

GUERRERO, V.M. (2004): “La marina de la Cerdeña nurágica”, Pyrenae 35 (1): 117155.

GUERRERO, V.M. (2007): "Barcas de Ubaid. Navegaciones predinásticas en el Golfo Pérsico", Complutum 18: 61-78.

GUERRERO, V.M. (2010): "Barcos calcolíticos (c. 2500/2000 BC) del Mediterráneo occidental”, Pyrenae 41 (2): 29-48.

HAWKING, S. (2011 [2001]): El universo en una cáscara de nuez. Crítica, Barcelona.

HERNANDO, A. (1988): Evolución interna y factores ambientales en la interpretación del Calcolítico del Sureste de la Península Ibérica. Una revisión crítica. Universidad Complutense, Madrid.

HORNUNG, E. (1999): El Uno y los Múltiples. Concepciones egipcias de la divinidad. Trotta, Madrid.

HOSKIN, M. (2009): "Orientations of dolmens of Western Europe”, Complutum 20 (2): 165-175.
HURTADO, V.; PERDIGONES, L. (1983): "Ídolos inéditos del Calcolítico en el Sudoeste Hispano", Madrider Mitteilungen 24: 46-58.

IWANISZEWSKI, S. (2009): "Por una astronomía cultural renovada", Complutum 20 (2): 23-37.

KRAGH, H. (2008): Historia de la cosmología. De los mitos al universo inflacionario. Crítica, Barcelona.

KUKAHN, E. (1962): "Los símbolos de la Gran Diosa en la pintura de los vasos ibéricos levantinos", Caesaraugusta 19-20: 79-85.

LAZARICH, M. (1999): El campaniforme en Andalucía occidental. Universidad de Cádiz, Cádiz. Ed. informática y microfichada.

LAZARICH, M. (2005): "El campaniforme en Andalucía”, en M.A. Rojo-Guerra y otros, El campaniforme en la Península Ibérica y su contexto europeo: 351-370.Junta de Castilla y León Universidad de Valladolid, Valladolid.

LEISNER, G. y V. (1943): Die Megalithgräber der Iberischen Halbinsel: der Süden. Walter de Gruyter \& Co., Berlin.

LINARES, J.A. (2011): Territorios, paisajes y arquitecturas megalíticas. Guía del megalitismo en la provincia de Huelva. Junta de Andalucía, Sevilla.

LÓPEZ MONTEAGUDO, G.; SAN NICOLÁS, M.P. (1996), “Astarté-Europa en la Península Ibérica. Un ejemplo de interpretatio romana", en M.A. Querol y T. Chapa (ed.), Homenaje al profesor Manuel Fernández-Miranda, en Complutum Extra 6 (I): 451-470.

LÓPEZ PAYER, M.G. (1988): La pintura rupestre en Sierra Morena oriental. Universidad Complutense, Madrid.

LULL, J. (2004): La astronomía en el antiguo Egipto. Universidad de Valencia, Valencia.

LUZÓN, J.M. (1988): "Los hippoi gaditanos", Congreso Internacional «El Estrecho de Gibraltar», tomo I: 445-458. UNED, Madrid.

MARÍN, M.C. (2011): "Santuarios prerromanos de la costa atlántica andaluza", en M.C. Marín (coord.), Cultos y ritos de la Gadir fenicia: 491532. Universidad de Cádiz - Universidad de Sevilla, Cádiz.

MARTÍ, B.; HERNÁNDEZ, M.S. (1988): El Neolític valencià. Art rupestre $i$ cultura material. Diputación de Valencia, Valencia. 
MARTÍN, D.; CÁMALICH, M.D. (1982): "La “cerámica simbólica" y su problemática (aproximación a través de los materiales de la colección L. Siret)", Cuadernos de Prehistoria de la Universidad de Granada 7: 267-306.

MAS, M. (2001): "Estructuras iconográficas e identificación de especies (secuencias iniciales y finales del arte postpaleolítico "esquemático")", Quaderns de Prehistòria $i$ Arqueologia de Castelló 22: 147-182

MAS, M. (2005): La cueva del Tajo de las Figuras. UNED, Madrid.

MAS, M.; FINLAYSON, C. (2001): "La representación del movimiento y la actitud (antropomorfos y zoomorfos) en los motivos pictóricos de los abrigos rocosos de Sierra Momia (Benalup-Casas Viejas, Cádiz)", Espacio, Tiempo y Forma, Serie I, Prehistoria y Arqueología 14: 185-202.

MAURA, R. (2011): Arte prehistórico en las tierras de Antequera. Junta de Andalucía, Sevilla.

MELLER, H. (2002): "Die Himmelsscheibe von Nebra - ein frühbronzezeitlicher Fund von aussergewöhnlicher Bedeutung", Archäologie in Sachsen-Anhalt I: 7-20.

MELLER, H. (2004): "El disco celeste de Nebra", Investigación y Ciencia 335: 70-75.

MOLINA, F.; CÁMARA, J.A. (2005): Los Millares. Guía del yacimiento arqueológico. Junta de Andalucía, s.l.

PÁSZTOR, E. (2009): “An archaeologist's comments on prehistoric European astronomy", Complutum 20 (2): 79-94

PÁSZTOR, E.; ROSLUND, C. (2007): “An interpretation of the Nebra disc", Antiquity 81 (312): $267-$ 278.

RENFREW, C. (1967): "Colonialism and megalithismus", Antiquity XLI: 276-288.

RENFREW, C. (1988): Archaeology and language: the puzzle of Indo-European origins. Cambrigde University Press, New York.

ROBINS, G. (1995): "Mathematics, astronomy and calendars in pharaonic Egypt", en J. Sasson (ed.), Civilization of the ancient Near East: 1799-1813. Amazon, New York.

RUIZ-GÁLVEZ, M. (2005): "Representaciones de barcos en el arte rupestre: piratas y comerciantes en el tránsito de la Edad del Bronce a la Edad del Hierro", Mayurqa 30: 307-339.
SANCHIDRIÁN，J.L.; MÁRQUEZ，A.M. (2003): "Radiodataciones y sus repercusiones en el arte prehistórico malagueño", Mainake XXV: 275292.

SEILD, U. (1989): Die babylonischen KudurruReliefs. Symbole mesopotamischer Gottheiten. Universitätsverlag Freiburg, Freiburg.

SCHLOSSER, W. (2002): "Zur astronomischen Deutung der Himmelsscheibe von Nebra", Archäologie in Sachsen-Anhalt I: 21-23.

SCHLOSSER, W. (2004): "El disco de Nebra, ¿un calendario agrícola?", Investigación y Ciencia 335: $76-83$.

SCHNEIDER, E.D.; SAGAN, D. (2008): La termodinámica de la vida. Tusquets, Barcelona.

SIRET, L. (1907): Orientaux et occidentaux en Espagne aux temps préhistoriques (Revue des Questions Scientifiques). Joseph Polleunis, Bruxelles.

SIRET, L. (1908): "Religions néolithiques de l'Ibérie", Revue Préhistorique III: 7-13.

SPRAJC, I. (1996): Venus, lluvia y maíz: simbolismo y astronomía en la cosmovisión mesoamericana. Instituto Nacional de Antropología e Historia, México D.F.

TOVAR, A. (1962): "Papeletas de Geografía Turdetana", Homenaje al profesor Cayetano de Mergelina: 813-819. Universidad de Murcia, Murcia.

VALERA, A.C. (2008): "Mapeando o Cosmos. Uma abordagem cognitiva aos recintos da Pre-Historia Recente", ERA Arqueologia 8: 112-127.

VALERA, A.C.; BECKER, H. (2011): “Cosmologia e recintos de fossos da Pre-Historia Recente: resultados da prospeccao geofisica em Xancra (Cuba, Beja)", Apontamentos de Arqueologia $e$ Património 7: 23-32.

WELLS, R.A. (1992): “The mythology of Nut and the birth of Ra", Studien zur Altägyptischen Kultur 19: 305-321.

WENGROW, D. (2007): La arqueología del Egipto arcaico. Transformaciones sociales en el noreste de África [10.000-2650 A.C.]. Bellaterra, Barcelona. 